\title{
COMMENTS
}

\section{FEDERAL COMITY, OFFICIAL IMMUNITY, AND THE DILEMMA OF SEGTION 1983}

Section 1983 of title 42, United States Code, provides a civil remedy in the federal courts for persons whose federal rights have been denied by anyone acting "under color of" state law. Typically, those who act "under color of" state law are state officials-ranging from governor to policeman. However, in many section 1983 suits, the purpose of the statute conflicts with the policy of protecting the working balance between the states and the federal government, or with the goal of ensuring impartiality of decision-making by state officials. The dilemma thus posed has been resolved by federal courts in various ways, depending on the type of state official or state function involved. This comment seeks to identify the solutions which the courts have adopted.

$\mathrm{T}$

HE JUDICIAL EFFORT to assure citizens their constitutional rights has been one of the dominant themes of American history for almost two decades. ${ }^{1}$ In many recent cases, the statutory starting point has been the enactments of the Reconstruction Congresses. ${ }^{2}$ One such statute was originally enacted in 1871 as part of the Third Enforcement $\mathrm{Act}^{3}$ and is presently codified in section 1983 of title 42 of the United States Code, which reads as follows:

Every person who, under color of any statute, ordinance, regulation, custom, or usage, of any State or any Territory, subjects, or

${ }^{1}$ Landmark decisions of the Supreme Court in recent years include Miranda v. Arizona, 384 U.S. 436 (1966) (criminal confessions); Katzenbach v. McClung, 379 U.S. 294 (1964) (public accommodations integration); Escobedo v. Illinois, 378 U.S. 478 (1964) (criminal confessions); Reynolds v. Sims, 377 U.S. 533 (1964) (reapportionment); Engle v. Vitale, 370 U.S. 421 (1962) (establishment of religion); Mapp v. Ohio, 367 U.S. 643 (1961) (freedom from illegal search and seizure); and Brown v. Board of Educ., 347 U.S. 483 (1954) (school desegregation).

${ }^{2}$ Leading cases in which Reconstruction statutes figured prominently include United States v. Price, 383 U.S. 787 (1966) [18 U.S.C. $\$ 242$ (1964); formerly Act of May 31, 1870 , ch. $114, \S 17,16$ Stat. 144, as amended, REv. STAT. $\$ 5510$ (1875)]; United States v. Guest, 383 U.S. 745 (1966) [18 U.S.C. $\$ 241$ (1964); formerly Act of May 31, 1870, ch. 114, §6, 16 Stat. 141]; McLaughlin v. Florida, 379 U.S. 184 (1964) [REv. STaT. \$ 1977 (1875), 42 U.S.C. $\$ 1981$ (1964); formerly Act of May 31, 1870, ch. 114, § 16, 16 Stat. 144]; Wheeldin v. Wheeler, 373 U.S. 647 (1963) [REv. STAT. $\$ 1980$ (1875), 42 U.S.C. $\$ 1985$ (3) (1964); formerly Act of April 20, 1871, ch. 22, §2, 17 Stat. 13]; and United States v. Baruett, 330 F.2d 369 (5th Cir. 1963), aff'd, 376 U.S. 681 (1964) [10 U.S.C. \$333 (1964); formerly Act of April 20, 1871, ch. 22, \$3, 17 Stat. 14].

3 Act of April 20, 1871, ch. 22, 17 Stat. 13. 
causes to be subjected, any citizen of the United States or other person within the jurisdiction thereof to the deprivation of any rights, privileges, or immunities secured by the Constitution and laws, shall be liable to the party injured in an action at law, suit in equity, or other proper proceeding for redress. ${ }^{4}$

The statute's language sets forth the two requirements for imposing liability: ( 1 ) there must be a deprivation of "rights, privileges, or immunities secured by the Constitution and laws"; and (2) the defendant causing the deprivation must be acting "under color of" state law. ${ }^{5}$ The first requisite merely rephrases the fourteenth amendment: ${ }^{6}$ any right guaranteed by the amendment is made the basis for a civil remedy. The second was suggested by the language of the amendment itself, which affords protection only if a state violates a federal right, privilege, or immunity. By requiring that a defendant be acting "under color of" state authority when depriving others of rights, section 1983 sufficiently satisfied the "state action" requirement. ${ }^{7}$

The implementation of these two requisites has proved more difficult than a perusal of the statutory language would suggest. One major problem has been the delineation of the scope of rights protected by section $1983 .{ }^{8}$ However, the primary focus of this

“REv. StaT. $\$ 1979$ (1875), 42 U.S.C. $\$ 1983$ (1964). Section 1983 is dervied from $\S 1$ of the Act of April 20, 1871. When the 1871 Act was reenacted in the Revised Statutes (1875), numerous changes in wording were made in $\$ 1$ by the revisors. However, since these changes simply broadened the scope of the rights which could be vindicated under the statute, they are of no consequence for purposes of this comment. See generally Shapo, Constitutional Tort: Monroe v. Pape, and the Frontiers Beyond, $60 \mathrm{Nw}$. U.L. REv. 277 (1965).

5 E.g., Monroe v. Pape, 365 U.S. 167 (1961); DeWitt v. Pail, 366 F.2d 682 (9th Cir. 1966); Mosher v. Beirne, 357 F.2d 638 (8th Cir. 1966); Haldane v. Chagnon, 345 F.2d 601 (9th Cir. 1965); Nesmith v. Alford, 318 F.2d 110 (5th Cir. 1963), cert. denied, 375 U.S. 975 (1964); Marshall v. Sawyer, 301 F.2d 639 (9th Gir. 1962); Cohen v. Norris, 300 F.2d 24 (9th Cir. 1962).

'See Conc. Grobe, 42d Cong., 1st Sess. 566, 698 (1871) [covering 1833-1873] (remarks of Senator Edmunds); $i d$. at app. 79 (remarks of Representative Perry). Representative Duke objected to the characterization of $\S 1983$ as a rephrasing of the fourtecnth amendment, claiming instead that it was an effort to extend federal power beyond the amendment's limitations: "The original text of the Constitution and the fourteenth amendment both use the terms 'privileges' and 'immunities,' and none other. Why was not this language adhered to? ... Now, sir, $I$ ask, were not the words 'any right' interpolated in order to give color of jurisdiction to the Federal courts in all cases whatever?" Id. at app. 91 .

${ }^{7}$ See United States v. Price, 383 U.S. 787, 794 n.7 (1966); notes 86-88 infra and accompanying text. For a useful collection of secondary sources discussing the concept, sec Van Alstyne, Mr. Justice Black, Constitutional Review, and the Talisman of State Action, 1965 Duke L.J. 219, 222 n.6, 231 n.34.

${ }^{8} \mathrm{~A}$ discussion of the scope of rights protected by $\S 1983$ is beyond the purview of 
comment will be the meaning of the phrase "under color of any statute ... of any State," the doctrine of official immunity, and the principle of federal comity as these three concepts relate to and affect the issue of who may be liable under this enactment. After a brief inquiry into the evolution and present meaning of the phrase "under color of" and the reasons underlying the doctrines of immunity and comity, this comment will examine in detail the liability under section 1983 of state officials, including judges, prosecutors, clerks of court and other ministerial officers, legislators, members of school boards and city councils, high executive officers, prison and mental hospital administrators, and law enforcement officials.

\section{The Enactment of Section 1983}

To facilitate a meaningful discussion of the question of who may be held liable under the statute, an understanding of its inception is helpful. The enacting legislators viewed the predecessor of section 1983 as part of a comprehensive congressional plan-the Third Enforcement Act ${ }^{9}$-designed generally to combat the lawlessness that allegedly existed in the South in $1871^{10}$ and specifically to provide federal remedies for asserted denials of newly-granted fourteenth

this comment. However, the issue has been extensively treated elsewhere. See generally Poole, Statutory Remedies for the Protection of Givil Rights, 32 ORE. L. REv. 210 (1953); Shapo, Constitutional Tort: Monroe v. Pape, and the Frontiers Beyond, 60 Nw. U.L. REv. 277 (1965); Comment, Immunity of Public Officials From Liability Under the Federal Civil Rights Acts, 18 ARK. L. Rev. 81 (1964); Comment, The Civil Rights Acts and Mr. Monroe, 49 CALIF. L. REv. 145 (196I); Note, Liability of Public Officers to Suit Under the Civil Rights Acts, 46 Convm. L. REv. 614 (1946); Note, The Doctrine of Official Immunity Under the Civil Rights Acts, 68 HARv. L. REv. 1229 (1955); Note, The Proper Scope of the Civil Rights Acts, 66 HARv. L. REv. 1285 (1953); Note, 42 U.S.C. \$1983-Civil Remedy-Its Circumvention and Emasculation, 12 How. L.J. 285 (1966); Note, Civil Rights Act Section 1983: Abuses by Law Enforcement Officers, 36 IND. L.J. 317 (1961); Note, Section 1983: A Civil Remedy for the Protection of Federal Rights, 39 N.Y.U.L. REv. 839 (1964); Note, The Civil Rights Act of 1871: Continuing Vitality, 40 Notre Dame LAw. 70 (1964).

- Act of April 20, 1871, ch. 22, 17 Stat. 13.

${ }^{10} \mathrm{The}$ alleged lawlessness and disorder in the South was the overriding concern in the Congressional debates. See, e.g., Cong. Globe, 42d Cong., Ist Sess. 320 (1871) [covering 1833-1873] (remarks of Representative Stoughton); id. at 436 (remarks of Representative Cobb); id. at 459 (remarks of Representative Coburn); id. at 653 (remarks of Senator Osborn); id. at 655 (remarks of Senator Sawyer); id. at app. 78 (remarks of Representative Perry); $i d$. at app. 185 (remarks of Representative Platt); id. at app. 190 (remarks of Representative Buckley); id. at app. 263 (remarks of Representative Barry); $i d$. at app. 283 (remarks of Representative Stevenson); $i d$. at app. 307 (remarks of Representative Maynard); id. at app. 312 (remarks of Representative Burchard). See generally Gressman, The Unhappy History of Civil Rights Legislation, 50 MrCH. L. REv. 1323 (1952). 
amendment rights. ${ }^{11}$ According to the Republican proponents, the major reasons for the denials of federal rights were the organized crime and violence fomented by the $\mathrm{Ku} K \mathrm{Klux} \mathrm{Klan},{ }^{12}$ the allegedly continuing attitude of rebellion among southern leaders, ${ }^{13}$ and the conspiracy by the Democratic Party and the Klan to drive the Republicans from the South. ${ }^{14}$ It was felt that these conditions had rendered state governments either incapable or unwilling to protect the rights of their citizens. ${ }^{15}$ Reasoning from this premise, the Republicans conceived it the duty of Congress to respond with a remedy. ${ }^{16}$ Under the comprehensive plan of the Third Enforcement

11 Representative Shellabarger of Ohio, floor manager of the bill in the House, re. marked that "the provisions of the fourteenth amendment are wholly devoted to securing the equality and safety of all the people, as is this section [the predecessor of $\S 1983]$, and, indeed, the entire bill." CoNG. Globe, 42d Cong., 1st Sess. app. 68 (1871) [covering 1833-1873]. See $i d$. at 429 (remarks of Representative McHenry); id. at 461 (remarks of Representative Roberts); id. at app. 185 (remarks of Representative Platt). See generally Davis, The Federal Enforcement Acts, in STUDIEs in SOUTHERN HIsTonY AND PoLrTICs 205, 216-17 (1914).

12 According to Representative Burchard, "in portions of the Union secret organizations exist, banded together to prevent the free exercise of civil and political rights. Through their agency the lives and persons of political opponents are doomed to violence and outrage and the perpetrators of the crime screened from detection and punishment. Where they have sprung up life is insecure and murder goes unpunished. The victims of their hate, bruised and maimed for life, abandoning home and possessions, are compelled to flee in terror to other regions for safety." Cong. GLOBE, 42d Cong., lst Sess. app. 312 (1871) [covering 1833-1873]. See, e.g., id. at 320 (remarks of Representative Stoughton); $i d$. at 686 (remarks of Senator Schurz); id. at app. 184-85 (remarks of Representative Platt); $i d$. at app. 263 (remarks of Representative Barry); id. at app. 283-84 (remarks of Representative Stevenson). See generally RANDALI \& Donald, The Crvil WAR and Reconstruction 682-85 (2d ed. 1961).

${ }^{13}$ After an independent study of the South, Senator Schurz-a "reformed Radical"reported that the disorders in the South "had their origin in the baffed pro-slavery spirit of the people lately in rebellion .... [T]here can be no doubt as to the condition of the popular mind in the late rebel states which brought forth the condition of things which we are now deploring." CoNG. GLOBE, 42d Cong., 1st Sess. 686 (1871) [covering 1833-1873]. See, e.g., id. at app. 190 (remarks of Representative Buckley). Contra, id. at 397-99 (remarks of Representative Roosevelt). See generally RANDALL \& DONALD, op. cit. supra note 12 , at 596 .

14 E.g., Cong. Globe, 42d Cong., 1st Sess. 320 - (1871) [covering 1839-1873] (remarks of Representative Stoughton); id. at 412-13 (remarks of Representative Roberts); id. at 436-37 (remarks of Representative Cobb); id. at 441-43 (remarks of Representative Butler); id. at app. 203 (remarks of Representative Garrett); id. at app. 276.77 (re. marks of Representative Porter).

${ }^{15}$ E.g., $i d$. at 368 (remarks of Representative Sheldon); id. at 456 (remarks of Representative Coburn); id. at 486 (remarks of Representative Tyner); id. at 487 (remarks of Representative Lansing); $i d$. at 653 (remarks of Senator Osborn); $i d$. at 686 (remarks of Senator Schurz); id. at app. 300 (remarks of Representative Stevenson); id. at app. 307-08 (remarks of Representative Maynard).

${ }_{10}$ Representative Austin Blair, in commenting on Congress's duty "to protect the citizens against armed bands of assassins," succinctly stated the Republican position: "It ought to be the duty of both the State and the nation to do this; and if the State 
Act, ${ }^{17}$ the enacting ]egislators attempted to rectify alleged denials of civil rights in two steps: first, by providing various criminal and military procedures for use against the Klan and other groups which might deny federal rights to any citizen; ${ }^{18}$ and secondly, by authorizing civil actions against both persons who fail to enforce the law equally and those who conspire to deprive others of their federal rights. ${ }^{19}$

The Democratic opposition condemned the Third Enforcement Act as disruptive of the federal-state balance because it permitted unwarranted federal intervention in local affairs. ${ }^{20}$ Although the act

will not, the nation must." Id. at app. 73; see, e.g, id. at 332 (remarks of Representative Hoar); id. at 604 (remarks of Senator Pool); id. at 653 (remarks of Senator Osborn); $i d$. at app. 68 (remarks of Representative Shellabarger); id. at app. 85 (remarks of Representative Bingham); $i d$. at app. 149 (remarks of Representative Garfield); $i d$. at app. 277 (remarks of Representative Porter). See generally Davis, supra note 11, at 206-07.

${ }^{17}$ See generally Comment, Federal Intervention in the States for the Suppression of Domestic Violence: Constitutionality, Statutory Power, and Policy, 1966 Duke L.J. 415, 419 n.23.

${ }^{18}$ Sections 3 (presently 10 U.S.C. $\$ 333$ (1964)) and 4 (17 Stat. 14 (1871), expiring according to its own terms) of the Third Enforcement Act were designed to give the President authority to send troops to the South and to suspend habeas corpus, if need be, in order to suppress Klan violence. Section 2 (REv. STAT. $\$ \S 629,699,5336,5406-07$, $5518,5519,5520$ (1875)) provided criminal penalties for those who conspired to obstruct justice, hinder an officer in the performance of his duty, or deprive others of rights. Most of these provisions of $\S 2$ have been either repealed or declared unconstitutional. See Comment, Federal Intervention in the States for the Suppression of Domestic Violence: Constitutionality, Statutory Power, and Policy, 1966 Duke L.J. 415, 419 n.23.

President Grant immediately put these federal remedies into operation against the Klan. Hundreds of arrests and convictions were the result. Federal troops were dispatched to areas of serious outlaw activity. See RANDALL \& DoNALD, op. cit. supra note 12, at 684. "By such methods the Klan was effectively dispersed. Its existence virtually came to an end in 1871." Ibid.

${ }^{10}$ One original civil action provided in $\$ 2$ of the 1871 Act (REv. STAT. $\$ 1980$ (1875), 42 U.S.C. $\$ 1985$ (3) (1964)) was designed to afford relief for conspiracy to deprive others of federal rights. This remedy was severely restricted by the Supreme Court in Collins v. Hardyman, 341 U.S. 651 (1951). The other civil action was $\$ 1$ of the 1871 Act, which grounded its remedy on direct violation of federal rights by persons acting "under color of" state law. (REv. STAT. \$1979 (1875), 42 U.S.C. § 1983 (1964)).

${ }^{20}$ Representative Archer of Maryland opposed the Third Enforcement Act because he felt it represented a usurpation of power by the federal government. Thus, he noted that "of the first and second sections, it is enough to say that they are in direct conflict with the reserved rights of the states as they have heretofore been understood and exercised by the states through their own laws and tribunals." CoNG. GLOBE, 42d Cong., Ist Sess. 373 (1871) [covering 1833-1873]. For similar objections, see, e.g., id. at 361 (remarks of Representative Stwann); id. at 366 (remarks of Representative Arthur); id. at 384 (remarks of Representative Lewis); id. at 395 (remarks of Representative Rice); $i d$. at 454 (remarks of Representative Cox); $i d$. at app. 50 (remarks of Representative Kerr); $i d$. at app. $74-75$ (remarks of Representative Wood); $i d$. at app. 207-08 (remarks of Representative J. Blair). 
was formally national in scope, the Democrats felt that it was aimed exclusively at the South and therefore unjustified, arguing that violence in the South was no more serious than that in the North or West. ${ }^{21}$ Even if the disorder as characterized by the Republicans ${ }^{22}$ did exist in the South, the Democrats blamed incompetent and corrupt Republican state governments for their tolerance of the situation, ${ }^{23}$ and suggested amnesty for southern leaders as the means for obtaining capable men to hold offices then held by Negroes. ${ }^{24}$ Finally, they urged that Congress lacked the power to enact legislation to enforce the fourteenth amendment. ${ }^{25}$ Albeit Democrats and Republicans disagreed as to the cause and extent of the disorder in the South, both asserted that the southern state governments were either unable or unwilling to carry out their proper governmental duties. $^{26}$ Thus, with the failure of state government clearly stated by both parties, the proponents of the Third Enforcement Act un-

${ }^{21}$ E.g., id. at 336 (remarks of Representative Whithorne); id. at 361 (remarks of Representative Swann); id. at 600-01 (remarks of Senator Saulsbury); id. at app. 50 (remarks of Representative Kerr); id. at 134-37 (remarks of Representative McCormick).

${ }^{22}$ See note 10 supra aud accompanying text.

${ }^{23}$ Representative Roosevelt, representing the views of many of his Democratic colleagues, honestly admitted dissatisfaction "with the laws, with the manner in which they are administered, and with the conduct of public officials in many portions of the South. ... The origin of this discontent is ... in our national legislature . . . . You, my Republican friends ... have turned over the affairs of the southern States to negroes; and it is no discredit to them to say that they possessed no qualifications for the positions which you insisted they should fill." CoNG. Grobe, 42d Cong., Ist Sess. 400 (1871) [covering 1833-1873]. For similar views, sec, e.g., id. at 356 (remarks of Representative Beck); $i d$. at app. 203-05 (remarks of Representative Garrett). See generally RANDALL \& DONALD, op. cit. supra note 12, at 624 .

z4 E.g., Cong. Globe, 42d Cong., 1st Sess. 431 (1871) [covering 1833-1873] (remarks of Representative McHenry); id. at 509-10 (remarks of Representative Eldridge); id. at app. 205 (remarks of Representative Garrett); id. at app. 300-01 (remarks of Representative Critcher). See the remarks of Representative Roosevelt, note 23 supra.

${ }^{25}$ Representative McHenry expressed the Democratic viewpoint regarding the method by which the fourteenth amendment was to be enforced: "It is for the States to enforce this provision by abstaining from the enactment of such laws as confict with it, and the courts to protect citizens by upholding and regarding the higher law of the Constitution." Id. at 429. See, e.g., id. at app. 49 (remarks of Representative Kerr); id. at app. 206 (remarks of Representative J. Blair). See gen. erally Davis, supra note 11 , at 207.

${ }^{26}$ Some Democrats readily admitted the incompetency of state governments in the South. See, e.g., Conc. Globe, 42d Cong., Ist Sess. 400 (1871) [covering 1833-1873] (remarks of Representative Roosevelt); id. at app. 205 (remarks of Representative Garrett); id. at app. 257-58 (remarks of Representative Holman); note 23 supra and accompanying text. Republican Representatives also made similar declarations with a view toward justifying extension of federal power. See notes 15-16 supra and accompanying text. 
doubtedly intended that the predecessor of section 1983 act not only as a vehicle for personal redress, but also as a negative incentive to state and local government officials, on penalty of personal liability, to perform their duties properly. ${ }^{27}$

Although the objectives of the Third Enforcement Act were copiously stated, ${ }^{28}$ debate construing the actual function and scope of section 1983 is scant. This dearth of discussion is partially explained by the fact that the Republican majority addressed itself chiefly to the constitutional justifications for the act and the necessity for its remedial provisions including section $1983 .{ }^{29}$ For the most part, Democrats were greatly disturbed by the criminal and military aspects of the proposed legislation, and therefore devoted less attention to the precursor of section 1983. However, the few Democrats who concerned themselves with that section objected with partisan fervor that state officials, including judges and legislators, would be subjected to examination in the federal courts, ${ }^{30}$ and that the balance

${ }^{27}$ In describing the forces which gave impetus to the passage of the Third Enforcement Act, the United States Commission on Civil Rights stated that one key factor was that "sentiment in favor of maintaining the new southern governments, by Federal force, if necessary, grew even stronger" as more and more reports of violence in the South filtered in. U.S. Civil Rights CoMm'N, FreEdom to THE FreE 48 (1963). The history of reconstruction before 1871 seems to bear out this conclusion. Thus, when the federal troops were sent into the South to carry out the military reconstruction ordered by Congress, they performed many police functions normally executed by state and local governments. However, the orders from the army headquarters show that this was not deemed desirable. Thus, in 1870 federal forces were commanded to cooperate with state civil authorities in making arrests, not to replace the state officials or do their duty for them. See Davis, supra note 11, at 213-15; cf. Randall \& Donald, op. cit. supra note 12, at 598. The Third Enforcement Act of 187I, by providing federal supplemental help for the States against the Klan, seems in accord with this command.

${ }^{28}$ See notes 18-19 supra and accompanying text.

${ }^{29}$ Several Republican sponsors of the act treated it section by section. See, e.g., Cong. Globe, 42d Cong., 1st Sess. 568, 698 (1871) [covering 1833-1873] (remarks of Senator Edmunds); id. at 575 (remarks of Senator Trumbull); id. at app. 67 (remarks of Representative Shellabarger); $i d$. at app. 71 (remarks of Representative A. Blair); id. at app. 78 (remarks of Representative Perry). However, their general attitude toward the predecessor of 1983 was summed up by Senator Edmunds of Vermont, floor manager of the bill in the Senate: "The first section is one that I believe nobody objects to, as defining the rights secured by the Constitution of the United States when they are assailed by any State law or under color of any State law . . . " Id. at 568. Several other Congressmen, including both Republicans and Democrats, did not discuss the predecessor of $\S 1983$ either because they considered other sections of the bill more demanding of their attention, or because they did not view it as making a great change in the law. See, e.g., $i d$. at 418 (remarks of Representative Bright); $i d$. at 50I (remarks of Representative Frelinghuysen); id. at app. 86 (remarks of Representative Storm); id. at app. 113 (remarks of Representative Farnsworth); id. at app. 209 (remarks of Representative J. Blair); $i d$. at app. 268 (remarks of Representative Sloss).

${ }^{30}$ Representative Lewis crystalized the Democratic opposition to the precursor of 
between federal and state governments would be radically altered by federal assumption of jurisdiction over cases previously adjudicated in state tribunals. ${ }^{31}$ The Republicans offered no retort to Democratic contentions of possible liability for judges and legislators and merely responded that the adoption of the fourteenth amendment had altered once and for all the prewar federal-state balance. ${ }^{32}$ Thus, legislative evidence on the issue of potential liability under the present section 1983 is inconclusive, the chief concern instead having been the purported extension of federal power.

\section{Judicial Evolution of Section 1983}

\section{"Under Color of" State Law}

For seventy years after its enactment, those who feared federal encroachment on state jurisdiction by the utilization of section 1983 had little complaint, as the statute was sparingly invoked. ${ }^{33}$ The first three Supreme Court cases involving section $1983^{34}$ did not attempt to define the meaning of the phrase "under color of." However, in

\$1983: "Sir, this bill is a systematic and apparently studied attack on our form of government. . . B By the first section, in certain cases, the judge of a State court, though acting under oath of office, is made liable to a suit in the Federal court and subject to damages for his decision against a suiter, however honest and conscientious that decision may be ...." Id. at 366; see, e.g., id. at 366 (remarks of Representative Arthur); $i d$. at 429 (remarks of Representative McHenry); $i d$. at app. 217 (remarks of Senator Thurman).

8I Democratic Senator Bayard vigorously objected to federal usurpation of state power: "Therefore, sir, I do protest against any such interpretation of this fourteenth amendment as shall in effect change the relations of the federal government to the states, and deprive the states by action of this government of their control of their domestic affairs." Id. at app. 243; see, e.g., id. at 366 (remarks of Representative Arthur); id. at 429 (remarks of Representative McHenry); id. at 451 (remarks of Representative Cox); id. at app. 216 (remarks of Senator Thurman); $i d$. at app. 304 (remarks of Representative Slater).

${ }^{32}$ Republican Representative Porter took the view that the fourteenth amendment imposed a duty on Congress to act: "When a class of citizens of the United States are systematically outraged .... and the State in which they reside is either incapable or unwilling to suppress the outrages, it seems to me very clear that such State has denied to this class the 'equal protection of the law,' and it becomes the duty of Congress under the amendment, to afford such protection." Id. at app. 277. Representative Bingham took an even stronger position: "The States never had the right, though they had the power, to inflict wrongs upon free citizens by a denial of the full protection of the laws; because all State officials are by the Constitution required to be bound by oath or affirmation to support the Constitution." Id. at app. 85.

${ }^{88}$ During the first fifty years of its existence, $\$ 1983$ was employed only twenty-one times. Comment, The Civil Rights Act: Emergence of an Adequate Civil Remedy?, 26 IND. L.J. 361, 363 (1951).

84 Lane v. Wilson, 307 U.S. 268 (1939); Nixon v. Herndon, 273 U.S. 536 (1927); Myers v. Anderson, 238 U.S. 368 (1915). 
upholding the liability of election officials who, while acting in accordance with state laws subsequently held unconstitutional, had deprived the plaintiffs of federal rights, the Court implicitly suggested that the phrase "under color of" meant that the offending persons must act "pursuant to" state law. ${ }^{35}$ Later, in Hague v. CIO, ${ }^{36}$ the Court seemed to apply a "pursuant to" construction while enjoining city officials from enforcing against a labor organization a local ordinance which contravened its members' rights of free speech and peaceful assembly. ${ }^{37}$

The interpretive development of the phrase "under color of" was facilitated by the judicial construction of the identical wording contained in section 1983's criminal counterpart, section 242 of title 18, United States Code..$^{38}$ In United States v. Classic, ${ }^{39}$ defendant election officials asserted that section 242 was inapplicable because they had acted contrary to and therefore not "pursuant to" Louisiana law, and hence had not operated "under color of" law. The Supreme Court rejected this contention, stating that "misuse of power, possessed by virtue of state law and made possible only because the wrongdoer is clothed with the authority of state law, is action taken

${ }^{35}$ Although the first three Supreme Court cases did not expressly rule that the phrase "under color of" meant "pursuant to," that definition may be implied from the result. In each case, the defendant election officials were held liable for acting according to valid state laws, which were only later declared unconstitutional in the suit against them. Ibid.; see Shapo, Gonstitutional Tort: Monroe v. Pape and the Frontiers Beyond, 60 Nw. U.L. REv. 277, 283-84 (1965).

${ }_{38} 307$ U.S. 496 (1939), 39 Colum. L. Rev. 1237, 52 HaRv. L. Rev. 320.

${ }^{37}$ Hague held that freedom to distribute information and the right to assemble, privileges protected by the fourteenth amendment, were deprived by the enforcement of the ordinance. Unable to agree with the Court's theory, Justices Stone and Reed concurred on the basis that the ordinance violated the due process clause. Despite this difference in theory, the decision opened the way for further inclusion of Bill of Rights freedoms within the scope of both the fourteenth amendment and $\S 1983$.

${ }^{3 s} 18$ U.S.C. $\$ 242$ (1964): "Whoever, under color of any law, statute, ordinance, regulation, or custom, willfully subjects any inhabitant of any State, Territory, or District to the deprivation of any rights, privileges, or immunities secured or protected by the Constitution or laws of the United States ... shall be fined not more than $\$ 1,000$ or imprisoned not more than one year, or both." (Emphasis added.) The key similarities between $\$ \S 242$ and 1983 lie in the fact that both employ the phrase "under color of" and both are directed at those who deprive others of federally protected rights. However, it should be noted that an element of wilfulness is required by $\$ 242$, whereas $\$ 1983$ contains no such requirement. Compare Screws v. United States, 325 U.S. 91, 105 (1945), with Monroe v. Pape, 365 U.S. 167, 187 (1961). A second difference between the two statutes is that the authority "under color of" which a defendant acts when prosecuted under $\$ 242$ need not be state law, as is true in the case of $\S 1983$.

${ }^{30} 313$ U.S. 299 (1941), 41 ColuM. L. REv. 1101 (1941), 20 N.C.L. REv. 93 (1941), 40 Mich. L. REv. 460 (1942). 
'under color of' state law."40 This expanded definition of "under color of," which encompassed acts cloaked with state authority, gained further acceptance in Snowden v. Hughes. ${ }^{41}$ Although the Snowden Court rejected a section 1983 claim on another ground, it implied that state officials who infringe federal rights while violating state law may be liable under section 1983.42 Later in Screws $v$. United States, ${ }^{43}$ which also involved section 242 , the Supreme Court reaffirmed the Classic approach and further clarified the meaning of the phrase "under color of."44 In Screws, the defendant sheriff, exercising his lawful power to make arrests, exceeded his authority to use force and caused the deprivation of the life of the victim without due process. Holding that he had nonetheless acted "under color of" state law, the Court stated that "under color of" meant "under pretense of" law, which included both authorized and unauthorized acts by "officers who undertake to perform their official duties." 45

The evolution of section 1983 from its enactment until the Screws decision produced two principal results. First, the defense that a state officer whose actions violate state law is not "under color of" law was thrice rejected. Secondly, in broadly interpreting the phrase "under color of" to mean "under pretense of," the Supreme Court delineated the outer circle for defining the scope of liability under section 1983. What operative facts would constitute a "pretense" of state authority remained to be determined; nonetheless the phrase at

${ }^{10} 313$ U.S. at 326 . In so holding, the Supreme Court merely adapted its earlier construction of the fourteenth amendment to $\$ 1983$ situations. See Home Tel. \& Tel. Co. v. City of Los Angeles, 227 U.S. 278 (1912).

11321 U.S. 1 (1944), 32 GEo. L. REv. 435.

${ }^{2}$ In Snowden, the plaintiff alleged that the defendant election officials had in. fringed his federal rights because they had refused in violation of Illinois law to place his name on a state ballot as Republican nominee for a state senate seat. Although the Supreme Court dismissed the claim by holding that plaintiff had no federallyprotected right to seek state political office, it did not discuss whether $\$ 1983$ was inapplicable because defendants had acted in violation of, rather than "pursuant to" state law.

48 325 U.S. 91 (1945), 44 Mich. L. REv. 814 (1946), 55 YALE L.J. 576 (1946); sce Cohen, The Screws Case: Federal Protection of Negro Rights, 46 Colum. L. REv. 94 (1946).

$\$ 325$ U.S. at 109-10.

15325 U.S. at 111. Speaking for the Court, Mr. Justice Douglas asserted: "It is clear that under 'color' of law means under 'pretense' of law. Thus acts of officers in the ambit of their personal pursuits are plainly excluded. Acts of officers who undertake to perform their official duties are included whether they hew to the line of their authority or overstep it." Ibid. Three justices dissented, citing the congressional history of $\$ 242$ for the proposition that "under color of" meant acting according to law. Id. at $142-44$. 
least meant that the offending person would be within the outer circle if he was "clothed with the authority of state law." 46

\section{Official Immunity}

The Supreme Court, in designating the outer circle of potential liability under section 1983, used as its gnideline the "under color of" language of the statute itself. Although the debates surrounding the predecessor of section 1983 evidence concern that certain particular officials would come within its purview, ${ }^{47}$ neither the enacting legislators, the text of the statute, nor the courts construing its provisions specifically mentioned the inner circle of limitations which courts subsequent to Screws have engrafted onto the statute. That limitation is the common law doctrine of official immunity. 48

Historically, common law official immunity has been characterized as a complete defense for "discretionary" officials of government sued for damages on the basis of acts performed within the scope of their duties. ${ }^{49}$ The doctrine is primarily designed to promote the fearless and impartial execution of duty by officials charged with the responsibility of making judicial, legislative, or executive policy decisions. ${ }^{50}$ However, before a public official may successfully rely on immunity

'United States v. Classic, 313 U.S. 299, 326 (1941); accord, Basista v. Weir, 340 F.2d 74, 80 (3d Cir. 1965).

${ }^{4}$ See note 30 supra and accompanying text; notes $125,137,155,178,197,210,223$, 255 infra and accompanying text.

${ }^{48}$ For cases discussing the "engrafting" of the immunity doctrine onto $\S 1983$, see, e.g., Tenney v. Brandhove, 341 U.S. 367 (1951); Robichaud v. Ronan, 351 F.2d 533 (9th Cir. 1965); Francis v. Lyman, 216 F.2d 583 (1st Cir. 1954); Cobb v. City of Malden, 202 F.2d 701 (1st Cir. 1953).

'See generally Davis, Administrative Officers Tort Liability, 55 Mrck. L. REv. 201 (1956); Gray, Private Wrongs of Public Servants, 47 CaLIF. L. REv. 303 (1959); Jaffe, Suits Against Governments and Officers: Damage Actions, 77 HARv. L. REv. 209 (1963). For a discussion of the immunity defense in relation to $\$ 1983$ 's equitable remedies, see note 69 infra and accompanying text.

${ }^{50}$ In Bradley v. Fisher, 80 U.S. (13 Wall.) 335 (1871), the first Supreme Court discussion of official immunity, the Court stated: "[I]t is a general principle of the highest importance to the proper administration of justice that a judical officer, in exercising the authority vested in him, shall be free to act upon his own convictions without apprehension of personal consequences to himself. Liability to answer to everyone who might feel himself aggrieved by the action of the judge, would be inconsistent with the possession of this freedom, and would destroy the independence without which no judiciary can either be respectable or useful." Id. at 347. The principle of Bradley was strongly reaffirmed in Pierson v. Ray, 386 U.S. 547 (1967), the Court stating that the fear of civil liability for decisional errors "would contribute not to principled and fearless decision-making but to intimidation." Id. at 554. For an excellent discussion of the rationale underlying official immunity, see Robichaud v. Ronan, 351 F.2d 533 (9th Cir. 1965); Norton v. McShane, 332 F.2d 855 (5th Cir. 1964), cert. denied, 380 U.S. 981 (1965). 
as a defense, two requisites must be met. First, he must be a "discretionary," as opposed to a "ministerial," official.51 In the context of official immunity, "discretionary" officials are those government officers charged with the duty of using their independent judgment to make important state decisions. ${ }^{52}$ A second requirement is that the official be acting within the scope of his duties. ${ }^{53}$ In making this determination, courts have been somewhat lenient because the line between authorized and unauthorized activity is often difficult to discern. Indeed, some acts of officials which are not specifically authorized have nevertheless been considered "within the scope of their duties." For example, a judge will normally be granted official immunity if his unauthorized action is merely in "excess of [his] jurisdiction," as opposed to having been done with "clear absence of all jurisdiction over the subject-matter." ${ }^{54}$ Other officials have been

6I "Present day decisions have tended to erode the common law meaning of many words and phrases used in legal literature, and as a result the word 'discretion' as it is now generally used in the law, is but an anemic facsimile of a robust ancestor." Weller v. Dickson, 314 F.2d 598, 60I (9th Cir.), cert. denied, 375 U.S. 845 (1963). Efforts continue to be made, however, to define discretion. For example, Jaffe has defined the term as the "power and duty to choose between valid alternatives." Jaffe, supra note 51, at 318. Yet, "almost all human conduct" involves the use of this kind of "discretion." See Note, The Discretionary Function Exception of the Federal Tort Claims Act, 66 HaRv. L. REv. 488, 490 (1953). Therefore, it is essential to delimit the term discretion, since even "ministerial" officers such as policeman may have to make some choices between valid alternatives in deciding whether an arrest should be made. See generally Davis, supra note 49 .

ธ2 See Dombrowski v. Eastland, 387 U.S. 82 (1967); Barr v. Matteo, 360 U.S. 564 (1959); United States v. Faneca, 332 F.2d 872 (5th Cir. 1964), cert. denied, 380 U.S. 971 (1965); Norton v. McShane, 332 F.2d 855 (5th Cir. 1964), cert. denied, 380 U.S. 981 (1965) The doctrine of immunity was intended to prevent the individual official from being confronted with the choice between loyalty to official duty and fear of personal liability. However, the state's well-being, which depends on an honest and unreserved exercise of judgment, is deemed to be sufficiently jeopardized to justify the denial of redress to injured persons only when such a division of loyalty affects "discretionary" public officials.

Factors which may help to determine whether an official may be classified as "discretionary" include the following: (1) the statute which creates the office uses the term discretion or other words of permission, as opposed to language of a mandatory nature; (2) the type of decision required of the officer requires expertise and judgment; (3) the officer's rank in the government hierarchy is deemed "high" as compared to other officials; (4) the decisions which the official makes affect great numbers of people, as contrasted to decisions which result in individual private torts. See Note, The Discretionary Function Exception of the Federal Tort Claims Act, 66 Harv. L. REv. 488, 491-98 (1953).

cs See Pierson v. Ray, 386 U.S. 547 (1967); Barr v. Matteo, 360 U.S. 564, $569-73$ (1959); Spalding v. Vilas, 161 U.S. 483, 498 (1896); Bradley v. Fisher, 80 U.S. (13 Wall.) 335, 351 (1871). See generally Davis, supra note 51 .

ss E.g., Bradley v. Fisher, 80 U.S. (13 Wall.) 335, 351 (1871); Bauers v. Heisel, 361 F.2d 581 (3d Cir. 1966), cert. denied, 386 U.S. 1021 (1967). An example of an action 
viewed as acting within the scope of their duties if their unauthorized acts fall within the range of activities typically associated with the responsibilities of their positions. ${ }^{55}$ In these situations, they are not required to justify their acts by showing specific authorization.

In the first case in which the defense of official immunity was asserted to a section 1983 claim for damages, Picking v. Pennsylvania R.R., ${ }^{56}$ the Court of Appeals for the Third Circuit denied its availability to a justice of the peace and a state governor. The court awarded damages after finding that these state officials had extradited the plaintiff from Pennsylvania to New York without due process. In denying the defense of immunity, the Picking court reasoned that the language of section 1983, requiring that "every person" who deprived another of federal rights "under color of" state law be held liable, admitted of no exceptions. ${ }^{57}$ However, Picking's expansive interpretation was short-lived. ${ }^{58}$ In the landmark case of Tenney v. Brandhove,59 the plaintiff sought damages from members of a California legislative committee whom he alleged had deprived him of his fourteenth amendment rights by publicly ridiculing and intimi-

\footnotetext{
"in excess of jurisdiction" is where a judge makes a mistake of law by admitting inadmissible evidence, which results in a conviction. Although his decision is reversable on appeal, he would still be protected from civil liability by judicial immunity. However, if he acts with "clear absence of jurisdiction," as when he obviously lacks jurisdiction over the subject matter, the doctrine of official immunity is not available to him. See, e.g., Bradley v. Fisher, supra. The reason a "discretionary official" is not held liable even though he acts "in excess of jurisdiction" was enunciated by the Supreme Court in Bradley: "Indeed some of the most difficult and embarrassing questions which a judicial officer is called upon to consider and determine relate to his jurisdiction, or that of the court held by him, or the manner in which the jurisdiction shall be exercised." Id. at 352. See Pierson v. Ray, supra note 53, for a modern statement of the Bradley rationale.

ss For example, an activity falling within the range of activities typically associated with a legislator is the issuance of a subpoena pursuant to a committee investigation. Dombrowski v. Eastland, 387 U.S. 82 (1967). For other examples of activities falling within an "outer perimeter" of duties associated with a particular office, see United States v. Faneca, 332 F.2d 872 (5th Cir. 1964), cert. denied, 380 U.S. 971 (1965).

${ }^{56}$ I5l F.2d 240 (3d Cir. 1945), cert. denied, 332 U.S. 776 (1947), 46 CoLuM. L. REv. 614 (1946), overruled, Bauers v. Heisel, 361 F.2d 581, 584 (3d Cir. 1966), cert. denied, 386 U..S. 1021 (1967).

57 I5I F.2d at 249. After finding that "every person" clearly included judges and governors, the court concluded that "Congress by enacting the Civil Rights Act sub judice intended to abrogate the privilege [of official immunity] to the extent indicated by that act and in fact did so." Id. at 250.

${ }^{88} \mathrm{~A}$ few lower federal court decisions purported to follow the Picking decision. See McShane v. Moldovan, 172 F.2d 1016 (6th Cir. 1949); Burt v. City of New York, 156 F.2d 791 (2d Cir. 1946).

so 341 U.S. 367 (1951), 3 MERGER L. REv. 221 (1951), 30 TEXas L. REv. 516 (1952), 20 U. Cinc. L. REv, 511 (1951).
} 
dating him before the committee because he had refused to testify. The Supreme Court, in reversing the lower court decision which had cited the Picking decision, ${ }^{60}$ stated that section 1983 did not abrogate the common law defense of legislative immunity. ${ }^{61}$ Acknowledging that the scope of section 1983 was not spelled out in the congressional debates, ${ }^{62}$ the Court nevertheless could not "believe that Congressitself a staunch advocate of legislative freedom-would impinge on a tradition so well grounded in history and reason by covert inclusion in [section 1983's] . . general language before us."63 Mr. Justice Frankfurter traced the "privilege of legislators to be free from arrest or civil process for what they do or say in legislative proceedings" 64 to its inception and found the privilege essential to our form of government, for it enables and encourages "a representative of the public to discharge his public trust with firmness and success."65 Thus, in spite of the use of the phrase "every person" in the statutory language of section 1983, the Tenney Court decreed that legislative immunity was available as a defense. ${ }^{66}$

${ }^{60}$ Brandhove v. Tenney, 183 F.2d 121, 124 (9th Cir. 1950).

a1 341 U.S. at 376 . In interpreting the Tenney decision two years later in Cobb v. City of Malden, 202 F.2d 701 (1st Cir. 1953), Judge Magruder of the Court of Appeals for the First Circuit stated: "[T]he Supreme Court in effect has held, in Tenney v. Brandhove, that the act merely expresses a prima facie liability, leaving to the courts to work out, from case to case, the defenses, by way of official privileges which might be appropriate to the particular case." Id. at 706. This same language was repeated in Francis v. Lyman, 216 F.2d 583, 588 (1st Cir. 1954). The Magruder view finds some support in the language used by Senator Thurman in opposing the enactment of the Third Enforcement Act: "I take it that if that [the interpretation of the meaning of the "rights" and "privileges," and of "any person" in the predecessor of $\S 1983$ ] is to be left to judicial decisions, as it is here entirely, without any definition on our part, there may be almost as many decisions as there are judges of the Federal courts . . . ." CoNG. GLobe, 42d Cong., Ist Sess. app. 216 (1871) [covering 1833-1873]. (Emphasis added.)

It seems clear that the "defenses by way of official privilege," which were to be worked out through judicial decision can only be those defenses properly recognized by the common law of the states. Thus, the Tenney Court based the legislative immunity exception to liability under $\$ 1983$ on English common law decisions which extended back as far as the sixteenth century. In the recent case of Pierson v. Ray, 386 U.S. 547 (1967), the Supreme Court affirmed that judicial immunity was also a defense to a $\S 1983$ damage claim because the congressional history of $\S 1983$ gave "no clear indication that Congress meant to abolish wholesale all common-law immunities." Id. at 554. (Emphasis added.) For a discussion of Pierson, see notes 169-77, 281-90 infra.

62341 U.S. at 376.

os Ibid.

${ }^{64}$ Id. at 372 .

${ }^{65} I d$. at 373, quoting from 2 Works of JAMEs WiLson (Andrews ed. 1896) 38.

${ }^{66} \mathrm{Mr}$. Justice Douglas sharply dissented in Tenney, stating that "if a committee departs so far from its domain to deprive a citizen of a right protected by the Constitution, I can think of no reason why it should be immune." Id. at 382. 
However, since Tenney was concerned only with legislators as defendants, the crucial question of the availability of official immunity to other state officials was left unanswered.67 Nevertheless, by ruling that the doctrine was a possible defense to a section 1983 claim against legislators, the decision did suggest a second criterion for determining who may be held liable under section 1983.68 Therefore, after Tenney, a tenative answer to the question of liability in damages under the statute was possible: to be held liable, a person had to fall within the outer circle of "under color of" state authority as defined in Classic and Screws, but outside the inner circle of officials entitled to official immunity.

\section{Federal Comity}

Although official immunity might insulate "discretionary" state officials from liability in damages, it could offer no protection against injunctive relief based on section 1983.69 Presumably, therefore, injunctions could be issued under the statute upon proof that federal rights would be deprived "under color of" state law. ${ }^{70}$ However, the possibility of frequent federal equitable intervention against state officials posed a serious threat to the working balance between federal and state governments. ${ }^{71}$ In order to protect this balance, the

\footnotetext{
or See note 91 infra.

${ }^{68}$ Although not expressly disapproving Picking, the Tenney Court's decision to allow legislative immunity as a defense had the effect of discrediting the Picking interpretation that $\$ 1983$ completely abrogated the doctrine of official immunity. See, e.g., Kenney v. Fox, 232 F.2d 288 (6th Cir.), cert. denied, 352 U.S. 855 (1956); Tate v. Arnold, 223 F.2d 782 (8th Cir. 1955); Francis v. Lyman, 216 F.2d 583 (Ist Cir. 1954); Cobb v. City of Malden, 202 F.2d 701 (Ist Cir. 1953). See generally Comment, Immunity of Public Officials from Liability Under the Federal Civil Rights Acts, 18 ARK. I. REv. 81 (1965); Note, The Doctrine of Official Immunity Under the Civil Rights Acts. 68 HARv. L. REv. 1229 (1955); Note, 42 U.S.C. \$1983-Civil Remedy-Its Circumvention and Emasculation, 12 How. L.J. 285 (1966).

${ }^{\circ}$ The rule that official immunity offers no protection against $\$ 1983$ injunctive relief was illustrated in Jordan v. Hutcheson, 323 F.2d 597 (4th Cir. 1963). In this suit for an injunction against a state legislative committee, the Court of Appeals for the Fourth Circuit explicitly stated that the Supreme Court's decision in Tenney, which permitted the use of official immunity as a defense to $\$ 1983$ damage suits, did not prohibit the issuance of an injunction. See, in addition, Due v. Tallahassee Theatres, Inc., 333 F.2d 630 (5th Cir. 1964). Several cases, by failing to discuss the immunity issue when injunctive relief was sought, have thereby implied that the immunity defense is not available. See Labat v. McKeithen, 361 F.2d 757 (5th Cir. 1966); Wojcik v. Palmer, 318 F.2d 171 (7th Gir.), cert. denied, 375 U.S. 930 (1963); Gately v. Sutton, 310 F.2d 107 (10th Cir. 1962).

${ }^{70}$ See note 5 supra and accompanying text.

${ }^{71}$ The Civil War and the constitutional changes which followed markedly altered the original balance between the states and the federal government, the federal gov-
} 
doctrine of federal comity has been developed. ${ }^{72}$

The doctrine of comity is an expression of the policy that federal courts should be restrained from interfering in state governmental proceedings in order to avoid embarrassing conflicts between the states and the federal government. ${ }^{73}$ Congressional recognition of

ernment emerging dominant. Randall \& Donald, The Givil War and Reconstruction 535, 633-37 (2d ed. 1961). However, the desirability of maintaining the states as vital instruments of government was still recognized. Thus, instead of adopting a version of the fourteenth amendment which gave Congress the "power to make all laws which shall be necessary and proper" to protect private citizens, CoNG. GloBE, 39th Cong., Ist Sess. 1034 (1866) [covering 1833-1873] (remarks of Representative Bingham), the Thirty-Ninth Congress approved the present negative limitation on state power, largely because many congressmen felt the Bingham version would make state governments superfluous. Thus, Representative Hale argned that if the Bingham version were passed, "all State legislation ... affecting the individual citizen, may be overridden, may be repealed or abolished, and the law of Congress established instead." Id. at 1063. Section 1983 was promulgated with the same concern for the continued functioning of state government. See note 27 supra and accompanying text. This desire to preserve the vitality of state governments is present today. State governments still play an essential role in the governmental structure of the United States, providing many public services which can best be handled at the local level and serving as small laboratories for government experimentation. See Roth v. United States, 354 U.S. 476, 496 (1957) (Harlan, J., dissenting); Hart, The Relations Between State and Federal Law, 54 Colum. L. Rev. 489 (1954).

Although the constitutional changes after the Civil War manifested a desire to retain states as meaningful instruments of government, they also represented a change in the concept of federalism. Whereas before the Civil War, the Constitution made a clear division of powers between the two levels of government, the Civil War amendments blurred this division by permitting federal courts and Congress to supervise the manner in which states performed their assigned functions. This new view of federalism was summarized in the debates over the predecessor of $\$ 1983$ : "It ought to be the duty of both the State and the nation to [protect citizens from Klan violence] ... ; and if the State will not, the nation must." Cong. GLOBE, $42 \mathrm{~d}$ Cong., Ist Sess. app. 73 (1871) [covering 1833-1873] (remarks of Representative A. Blair); sec notes 16, 32 supra for citations to other congressional statements expressing the same view. The power to determine the proper balance between the States and the federal government was an implicit part of the federal government's new supervisory role in the federal system. See Freund, Umpiring the Federal System, 54 Couur. L. REv. $561,562-63$ (1954). The view of federalism that the states are to be given reasonable opportunity to protect the rights of their citizens, but if they fail, then the federal government will provide such protection has not been unanimously accepted. Sec Monroe v. Pape, 365 U.S. 167, 202-59 (196I), (Frankfurter, J., dissenting); MarshalL, Federalism AND Crvil Rights (1964). However, there is impressive authority in support of it. See United States v. Guest, 383 U.S. 745 (1966); Cameron v. Johnson, 381 U.S. 741 (1965) (per curiam); Dombrowski v. Pfister, 380 U.S. 479 (1965); Comment, Theories of Federalism and Civil Rights, 75 YALE L.J. 1007 (1966).

${ }^{72}$ Just as the doctrine of official immunity created an inner circle of nonliability in damages under $\$ 1983$, so federal comity creates an inner circle of protection from injunctive relief. However, the compass of the two inner circles is not identical. Whereas the inner circle of immunity from damages is primarily determined by the kind of official-"discretionary" or "ministerial"-who is being sued, federal comity's inner circle is delineated chiefly by the nature of the state function which the plaintiff seeks to inhibit. Thus, comity will prohibit injunctive relief against state officials who 
the doctrine of federal comity is codified in section 2283 of title 28 , United States Code, which forbids federal courts from enjoining state court proceedings, "except as expressly authorized" by Congress. ${ }^{74}$ While this statutory restraint on federal equity jurisdiction applies only to cases which have been "commenced" in state courts, 75 state judicial proceedings constitute the type of state action which is frequently challenged in section 1983 suits for injunctive relief.76

are participants in a state court proceeding or a state legislative hearing, even if the official is a policeman or other "ministerial" officer. See notes 83-86 infra. However, an injunction may be issued against the same pohceman when he seeks to enforce state regulations violative of federal rights. See, e.g., Lankford v. Gelston, 364 F.2d 197 (4th Gir. 1966).

${ }^{33}$ The Supreme Court has explained the necessity for comity on these grounds: "We live in the jurisdiction of two sovereignties. Each has its own system of courts to interpret and enforce its Jaws, although in common territory. These courts could not perform their respective functions without embarrassing conflicts unless rules were adopted to avoid them." Wilson v. Schnettler, 365 U.S. 381, 385 (1961). Later in Dombrowski v. Pfister, 380 U.S. 479, 484-85 (1965), the Court stated that in order for federal courts to utilize comity to adjust the balance between state and federal governments, it must "be assumed that state courts and prosecutors will observe constitutional limitations as expounded by this Court, and that the mere possibility of erroneous initial application of constitutional standards will usually not amount to irreparable injury necessary to justify a disruption of orderly state proceedings." See generally U.S. Crvit, Rights COMM'N, LAw ENFORGEMENT: A REPORT ON EQUAI PROTECTION IN THE SOUTH 121-29 (1965).

7428 U.S.C. $\$ 2283$ (1964): “A court of the United States may not grant an injunction to stay proceedings in a State court except as expressly authorized by Act of Congress, or where necessary in aid of its jurisdiction, or to protect or effectuate its judgments." The predecessor of $\S 2283$ was originally $\S 5$ of the Act of March 2, 1793, ch. 22, 1 Stat. 334-35. It was later amended by the Judiciary Act of 1911 in 36 Stat. 1162 (1911) to apply specifically to proceedings in bankruptcy. The provision took its current form in the Judiciary Act of 1948, ch. 155, 62 Stat. 968 (1948). For an account of the legislative history of $\$ 2283$, see Note, 21 RuTGERs L. REv. 92, 97-105 (1966).

${ }^{75}$ The phrase "proceedings in a state court" has been said to include "all steps taken or which may be taken in the state court or by its officers from the institution to the close of the final process." Hill v. Martin, 296 U.S. 393, 403 (1935). See Developments in the Law-Injunctions, 78 HARv. L. REv. 995, 1048 (1965). Thus, $\$ 2283$ bars federal injunctions against state proceedings which have been instituted, but not those which are merely threatened. Furthermore, it has been noted that $\$ 2283$ has been applied only to federal injunctive actions against state criminal proceedings. U.S. Civil Rights Comm'N, Law Enforcement: A Report on EQUal Protection in the SOUTH 125-26 (1965).

${ }^{70}$ See, e.g., Baines v. City of Danville, 337 F.2d 579 (4th Cir. 1964), aff'd mem. 384 U.S. 890 (1966); Wojcik v. Palmer, 318 F.2d 171 (7th Cir.), cert. denied, 375 U.S. 930 (1963); Goss v. Illinois, 312 F.2d 257 (7th Cir. 1963); Gately v. Sutton, 310 F.2d 107 (10th Cir. 1962); Moss v. Jones, 288 F.2d 342 (6th Cir.), cert. denied, 368 U.S. 868 (1961). Section 2283 has an impact even broader than prohibiting injunctions against "state proceedings," for as the United States Commission on Civil Rights points out, "since it is not always possible to anticipate prosecutions of civil rights participants, intervention by the federal court is foreclosed in many cases." U.S. CrviL RIGHTS Comm'n, LAw Enforgement: A Report on Equar, Protection In the South 127 (1965). For the view that $\S 2283$ should not preclude $\S 1983$ injunctive actions against state court proceedings, see Note, 21 RUTGERS L. REv. 92 (1966). 
Thus, in order to avoid the application of section 2283, it has been argued that section 1983 is an "expressly authorized" exception to the ban on federal equitable intervention. Although a few courts have accepted this view, ${ }^{77}$ most have taken a contrary position..$^{78}$ These courts reason that since section 1983 provides a general grant of equity power, it is subject to the more specific limitation imposed by section 2283.79 Under this view, section 2283 seems a substantial limitation on the equitable remedy provided by section 1983 .

In addition to Congress's declaration of federal comity in section 2283, the Supreme Court has advanced its own version of comity, which extends beyond the limits of section 2283. In Douglas $v$. City of Jeannette, ${ }^{80}$ plaintiff Jehovah's Witnesses alleged that threatened state prosecutions for violations of a municipal ordinance which prohibited solicitations of orders for merchandise without a license would infringe their rights of speech and religion, and sought an injunction on the basis of section 1983. In upholding the denial of the injunction, the Court stated that federal courts should refuse "to interfere with or embarrass threatened proceedings in state courts save in those exceptional cases which call for the interposition of a court of equity to prevent irreparable injury which is clear and

\footnotetext{
"See Cooper v. Hutchinson, 184 F.2d 119, 124 (3d Cir. 1950); cf. United States v. Wood, 295 F.2d 772, 779 (5th Cir. 1961), cert. denied, 369 U.S. 850 (1962); Morrison v. Davis, 252 F.2d 102 (5th Cir.) (per curiam), cert. denied, 356 U.S. 968 (1958).

${ }^{78}$ See, e.g., Baines v. City of Danville, 337 F.2d 579 (4th Cir. 1964), aff'd mem. 384 U.S. 890 (1966); Goss v. Illinois, 312 F.2d 257 (7th Cir. 1963); Smith v. Village of Lan. sing, 241 F.2d 856 (7th Cir. 1957); Sexton v. Barry, 233 F.2d 220 (6th Cir.), cert. denied, 352 U.S. 870 (1956); Alesna v. Rice, 172 F.2d 179 (9th Cir. 1949) (dictum); Chaffee v. Johnson, 229 F. Supp. 445 (S.D. Miss. 1964), affd 352 F.2d 514 (5th Cir. 1965), cert. denied, 384 U.S. 956 (1966); Island S.S. Lines, Inc. v. Glennon, 178 F. Supp. 292 (D. Mass. 1959); U.S. Civil RIGHTS CoMm'n, LAw ENforgement: A Report on Equal ProTECTION IN THE SOUTH 126 (1965); Developments in the Law-Injunctions, 78 HARv. L. REv. 995, 1050-51 (1965).

${ }^{79}$ In Baines v. City of Danville, supra note 78, the Court of Appeals for the Fourth Circuit, in denying an injunction against state criminal proceedings, explained its view of $\S 1983$ in the context of $\S 2283$ as follows: Section 1983 "creates a federal cause of action, but with no suggestion, explicit or implicit, that appropriate relief shall include an injunction which another Act of Congress forbids. ... [E]quitable remedies are authorized, but only by a general jurisdictional grant. Creation of a general equity jurisdiction is in no sense antipathetic to statutory or judicially recog. nized limitations upon its exercise." Id. at 589. Thus, the court asserted that there was "no incompatability between a generally created equity jurisdiction and particularized limitations which restrict" such jurisdiction. Ibid. In fact, "if every grant of general equity jurisdiction created an exception to the anti-injunction statute, the statute would be meaningless." Ibid.
}

${ }^{80} 319$ U.S. 157 (1943), 11 U. KaN. CrTX L. Rev. 230. 
imminent. . . ."81 To justify this rule, the Court relied on the congressional policy against federal interference with state proceedings, as embodied in the predecessor of section 2283.82 Later, in Stefanelli $v$. Minard, ${ }^{83}$ the Court expounded further the rationale for judiciallydeclared federal comity. In Stefanelli, plaintiffs sought to enjoin under section 1983 the presentation of evidence by state policemen in a state trial, alleging that the evidence had been obtained by illegal search and seizure. The Court sustained the denial of the injunction on the basis of federal comity, announcing that the primary purpose of the doctrine was to ensure that federal courts "respect the proper balance between the States and the federal government in law enforcement."84 Furthermore, the Court noted that if federal courts adopted the practice of frequent intervention into state law enforcement, "every question of procedural due process of law-with its far flung and undefined range-would invite a flanking movement against the system of State courts by resort to the federal forum ...." 85 Such collateral attack on state administration of justice would expose every "state criminal prosecution to insupportable disruption." 86

81 Id. at 163 .

$82 I d$. at $162-63$.

88342 U.S. 117 (1951), 24 Rocky MT. L. REv. 374 (1952), 38 VA. L. REv. 514 (1952). The importance of this case to the doctrine of federal comity in the context of $\$ 1983$ is illustrated by the Court's statement of why it decided to hear the case: "Since it raises important questions touching the Civil Rights Act [\$ 1983] in the context of our federal system we brought the case here." 342 U.S, at 118.

84342 U.S. at 121. The Supreme Court stated its holding clearly: "We hold that the federal courts should refuse to intervene in State criminal proceedings to suppress the use of evidence even when claimed to have been secured by unlawful search and seizure. The maxim that equity will not enjoin a criminal prosecution summarizes centuries of weighty experience in Anglo-American law. It is impressively reinforced when not merely the relations between coordinate courts but between coordinate political authorities are in issue. The special delicacy of the adjustment to be preserved between federal equitable power and State administration of its own law, has been an historic concern of congressional enactment ..." Id. at 120.

${ }^{85} I d$. at 123 . The desire to prevent collateral attacks on rulings by state judges during trials was similarly expressed in Cleary v. Bolger, 371 U.S. 392, 401 (1963): An injunction "should not issue against a state official, at least where . . there is no evidence of a purpose to avoid federal requirements and the information has not been acquired by the state official in violation of a federal court order. Such direct intrusion in state processes does not comport with proper federal-state relationships."

86 342 U.S. at 123. In Dombrowski v. Pfister, 380 U.S. 479 (1965), the Supreme Court adhered to the theory of federal comity espoused in Douglas and Stefanelli: "[T]he Court has recognized that federal interference with a State's good faith administration of its criminal laws is particularly inconsistent with our federal framework." Id. at 484. In Pfister, plaintiffs sought a $\$ 1983$ injunction to restrain various state officials from threatening to prosecute them for alleged violations of Louisiana's subversive 
The Douglas-Stefanelli decisions applied the general principle of federal comity to law enforcement situations, other than those defined in section 2283, where there was a danger of inflaming federal-state relationships. However, neither decision dealt with the question whether comity prohibited section 1983 injunctive relief against state officials performing duties besides law enforcement. ${ }^{87}$ Nevertheless, the sweeping language of Stefanelli could be viewed as suggesting comity as a second inner circle of limitation on section 1983 relief. Thus, the general contours of liability of section 1983 have been delineated: the phrase "under color of" specifies which persons may be possible defendants to section 1983 claims; the doctrine of official immunity denies damages where their recovery would inhibit official decision-making; and the rule of federal comity restrains injunctive relief if there is a danger of upsetting the working balance between the state and federal governments.

\section{The Impact of Monroe v. Pape ${ }^{88}$}

Throughout the decade following Tenney and Stefanelli, lower federal courts applied the Screws-Tenney-Stefanelli interpretation in determining liability under section $1983 .{ }^{89}$ In the process, the broad scope of the remedy, as stated by the enacting legislators, was judicially restricted. Indeed, few state officials were found liable

activities law, asserting that their federal right to freedom of expression was being abridged. Applying the Douglas-Stefanelli formulation of the doctrine of federal comity, the Pfister Court ordered the district court to enjoin the state officials, deciding that the facts showed a danger of "irreparable injury." The Court found first that the "sensitive nature of constitutionally protected expression" demanded that immediate rehef be given when a state statute regulating it, such as the Louisiana act, was overbroad. Otherwise, irreparable injury could result from "the fact of the prosecution, unaffected by the prospects of its success or failure." Id. at 487. Secondly, when state officials threaten prosecution with no good faith intent of taking the case to trial, the purpose being instead to intimidate plaintiffs in the exercise of their rights, irreparable injury is "clear and imminent," for there is no opportunity for judicial review to correct possible deprivations of federal rights. In order to provide a remedy, injunctive relief under $\S 1983$ was available in this situation. Thus, the Pfister decision strengthened the original limitation of "irreparable injury" on the doctrine of comity, without modifying the doctrine itself. Subsequent to Pfister, the Supreme Court vacated and remanded the decision of a Mississippi federal district court for reconsideration in light of the Pfister decision. Cameron v. Johnson, 381 U.S. 741 (1965) (per curiam).

${ }^{87}$ See notes 129, 208 infra.

8s 365 U.S. 167 (1961), 1961 DUKE L.J. 452, 12 MERCER L. REv. 410 (1961); see Sperber, Monroe v. Pape: Redress Under the Civil Rights Act Redefined, 21 LAw iN Transition 197 (1961); The Supreme Court, 1960 Term, 75 HaRv. L. Rev. 40, $211-16$ (1961).

${ }^{80}$ See cases cited notes 168, 183, 227 infra and accompanying text. 
because of the rather narrow view of the scope of rights protected by the statute, ${ }^{90}$ because the doctrine of immunity was expanded to officials ranging from governors to plumbing inspectors, ${ }^{91}$ and because the concept of federal comity as defined in Stefanelli was widely applied.92 However, in Monroe v. Pape, ${ }^{93}$ the Supreme Court resuscitated section 1983 as a viable civil remedy. In Monroe, the plaintiffs alleged that the defendant policemen had broken into their home and had searched it without a warrant, in violation of their freedom from illegal search and seizure as protected by the due process clause of the fourteenth amendment, and that as policemen, they had acted "under color of" the laws and ordinances of the city of Chicago and the State of Illinois. In reversing the lower federal court's dismissal, the Supreme Court held that a claim for damages had been stated against the policemen, but not against the city of Chicago.94

Even though official immunity was not mentioned in Monroe, the obvious result seemed to be that policemen, to whom some lower federal courts after Tenney had on occasion implicitly extended im-

${ }^{80}$ The chief restriction on the type of violation which would give rise to a $\$ 1983$ cause of action was the requirement that the defendant have an intention to deprive another of federal rights before he could be found liable. See Hoffman v. Halden, 268 F.2d 280, 292-94 (9th Cir. 1959), overruled, Cohen v. Norris, 300 F.2d 24, 29-30 (9th Cir. 1962); Francis v. Lyman, 216 F.2d 583 (1st Cir. 1954). This restriction was applied to all fourteenth amendment violations, even though it originated as a requirement for proof of deprivation of equal protection only. See Snowden v. Hughes, 321 U.S. 1, 8 (1944). See generally Note, Civil Rights Act Section 1983: Abuses by Law Enforcement Officers, 36 IND. L.J. 317 (1961); Note, The Proper Scope of the Civil Rights Acts, 66 HARv. L. REv. 1285 (1953).

${ }^{91}$ For a listing of state officials who have claimed immunity as a defense to suits based on $\$ 1983$, see Shapo, Constitutional Tort: Monroe v. Pape and the Frontiers Beyond, 60 Nw. U.L. REv. 277, 310 n.166 (1965); Note, The Doctrine of Official Immunity Under the Civil Rights Acts, 68 HARv. L. REv. 1229, 1233-40 (1955); Comment, 42 U.S.C. \$1983-Civil Remedy-Its Circumvention and Emasculation, 12 How. L.J. 285, 290-92 (1966).

¿2 Federal courts liave been especially reluctant to interfere with state criminal proceedings. As a former Assistant Attorney General of the United States has written, "In the entire course of our federal legal history, there has been but a handful of occasions where a federal court enjoined a state from prosecuting criminal charges for any reason. ... Only once has a federal court issued an injunction to prevent unadorned abuse of police power ..." Marshali, Federalism and Crvil Rights 53.54 (1964).

${ }^{2} 365$ U.S. 167 (1961); see note 88 supra.

or In relieving the City of Chicago of liability, Mr. Justice Douglas noted the explicit rejection of a suggested amendment to the Act of April 20, 1871, which would have made municipalities liable if a judgment was returned unsatisfied against the defendant government officials. He felt this rejection was a persuasive indicium that the enacting Congress did not intend for municipalities to fall within the scope of the statutory phrase "every person." 365 U.S. at 191-92. For the text of the rejected amendment, see CoNG. GloBE, 42d Cong., 1st Sess. 704 (1871) [covering 1833-1873]. 
munity, ${ }^{95}$ would no longer be able to invoke the defense. ${ }^{06}$ This consequence increased the potential usefulness of the statute, particularly since police officers are a major source of alleged section 1983 violations. ${ }^{07}$ Monroe also revitalized section 1983 by holding that "the federal remedy is supplementary to the state remedy,"08 thereby negating the defense of exhaustion of state remedies. However, perhaps the greatest impact of the Monroe ruling was the broadening of the scope of rights encompassed by section 1983. As Mr. Justice Douglas read the legislative history of section 1983, the statute was passed to provide a federal remedy against those state officials who deprived others of rights by failing to enforce state laws properly. ${ }^{99}$ Consistent with his reading, he found that no purpose to deny rights to others need be proved against defendants to show a

${ }^{\circ 5}$ See, e.g., Stift v. Lynch, 267 F.2d 237 (7th Cir. 1959); Eaton v. Bibb, 217 F.2d 446 (7th Cir. 1954), cert. denied, 350 U.S. 915 (1955); Miles v. Armstrong, 207 F.2d 284 (7th Cir. 1953). Cases such as these often provided a practical immunity for police officers by holding that the police action complained of was not violative of federal rights. Tlus, many lower federal courts were somewhat dismayed by the Monroe decision. See Hardwick v. Hurley, 289 F.2d 529 (7th Cir. 1961).

${ }^{90}$ Monroe's implicit denial of the immunity defense did not mean, as was made clear by the Supreme Court in Pierson v. Ray, 386 U.S. 547 (1967), notes 281-90 infra and accompanying text, that the law enforcement officials could not avoid liability by showing that they had enforced the law in good faith and with probable cause. Id. at 555-57. However, the difference between immunity on the one hand and good faith-probable cause on the other is this: immunity from suit bars court inquiry $a b$ initio into the police official's decision, whereas the defense of probable cause and good faith requires full trial of the circumstances surrounding the decision and a jury determination of whether the facts reasonably support the official's decision.

${ }^{97}$ Although many courts have asserted that police violations of $\$ 1983$ are not identical to the torts of assault and battery, false arrest, and false imprisonment, sce e.g., Cole v. Smith, 344 F.2d 721 (8th Cir. 1965), the tort and the $\$ 1983$ offense scem operationally the same. See Nesmith v. Alford, 318 F.2d 110 (5th Cir. 1963), cert. denied, 375 U.S. 975 (1964); Hardwick v. Hurley, 289 F.2d 529 (7th Cir. 1961). Therefore, statistics on torts committed by policemen provide a measure of the need for $\$ 1983$ relief. For example, it has been reported that in 1933 alone, there were an estimated three and one-half million illegal arrests. See Hall, Police and Law in a Democratic Society, 28 IND. L.J. 133, 154 (1953). Another indication of the potential number of $\$ 1983$ claims against law enforcement personnel is shown by statistics for the year 1964. Thus, in 1,658 cities with a total population over $56,807,000$, a total of 75,078 (19.8\% of all arrests) persons arrested were released without charge, and 44,832 (11.9\%) were acquitted of the offense charged. U.S. BuREAU OF THE CENsus, STATISTICAL Austract OF THE UNITED STATES 151 (87th ed. 1966). It is reasonable to assume that many of these arrests would support a $\$ 1983$ cause of action.

${ }^{98} 365$ U.S. at 183; accord, McNeese v. Board of Educ., 373 U.S. 668 (1963).

${ }^{\circ}$ Speaking for the Court, Mr. Justice Douglas concluded: "It is abundantly clear that one reason the legislation [\$ 1983] was passed was to afford a federal right in fedcral courts because, by reason of prejudice, passion, neglect, intolerance or otherwise, state laws might not be enforced and the claims of citizens to the enjoyment of rights, privileges, and immunities guaranteed by the Fourteenth Amondment might be denied by the state agencies." 365 U.S. at 180. 
violation of due process. ${ }^{100}$ Finally, Mr. Justice Douglas reaffirmed the Classic-Screws view that the phrase "under color of" meant acting under pretense of state law, ${ }^{101}$ thus rejecting again the defense that one clothed with state authority, but acting in violation of it, was not operating "under color of" state law.

By enlarging the scope of rights which could give rise to section 1983 claims, by implicitly denying the defense of immunity to law enforcement officers, and by holding the federal remedy supplementary to state relief, Monroe enhanced the future utility of the statute as a guardian of individual federal rights. ${ }^{102}$ However, by increasing the likelihood that more section 1983 complaints would be instituted against all categories of state officials, the Monroe decision inevitably increased the danger that the valid purposes promoted by the doctrines of official immunity and federal comity in a section 1983 context might be defeated. ${ }^{103}$ Thus, to the extent that section 1983, as interpreted by Monroe, permits greater examination of state officials for making policy choices deemed incorrect in restrospect, the confidence and ability of the state to make its own decisions and to perform its functions independently is lessened. Therefore, federal courts after Monroe seem to have employed the doctrines of immunity and comity to protect the independent judgment of "discretionary" officials and to strike a meaningful federal-state balance which will encourage state self-development.

\section{Possible Defendants Under Section 1983}

By denominating possible defendants with the phrase "every person," the enactors of section 1983 created potential liability for

${ }^{100} \mathrm{Mr}$. Justice Douglas compared $\S 1983$ with its criminal counterpart, 18 U.S.C. $\$ 242$ (1964), which the Court in Screws v. United States, 325 U.S. 91 (1945), had said required "a specific intent to deprive a person of a federal right." Id. at 103; for the text of 18 U.S.C. $\$ 242$ (1964), see note 38 supra. However, $\$ 1983$ lacked the word "willfully" employed in $\$ 242$. Therefore, in Monroe, Mr. Justice Douglas concluded that "Section [1983] ... should be read against the background of tort liability that makes a man responsible for the natural consequences of his actions." Monroe v. Pape, 365 U.S. 167, 187 (1961); accord, Basista v. Weir, 340 F.2d 74, 79-81 (3d Cir. 1965).

${ }^{101} 365$ U.S. at 187. See generally notes $39-40,42-45$ supra and accompanying text.

102 Although Monroe involved a claim for damages only, the decision's broad rendering of the rights protected by $\$ 1983$ seems equally applicable in suits for equitable relief. Thus, since an intention to deprive another of due process no Ionger need be proved, the probabilities of establishing procedural due process claims against state officials performing judicial functions apparently will increase.

${ }^{103}$ See notes $49-55$ supra and accompanying text for the treatment of the doctrine of official immunity; see notes 73, 81-86 supra and accompanying text for a discussion of the purpose of federal comity. 
all persons who allegedly deprive others of federal rights "under color of" state law. However, the judicial implementation of the statute has not achieved this result. Frequently, the determinative factor of liability hinges on only one facet of a particular requirement, such as the "state action" issue embodied in the "under color of" limitation.104 For example, federal officers, who escape liability under section 1983 when performing their duties pursuant to a federal law, 105 will nevertheless be considered to act "under color of any statute ... of any State" when assisting a state officer in the enforcement of a state enactment. ${ }^{106}$ Indeed, a plethora of such distinctions must be scrutinized in determining liability under section 1983. In considering the requirements for liability, attention shall be directed initially to private persons as potential defendants.

\section{Private Persons}

The "under color of" language of section 1983 poses the greatest obstacle to an imposition of liability upon private persons. Since

${ }^{10}$ See note 7 supra and accompanying text.

${ }^{205}$ Federal officers found not liable under $\$ 1983$ because they were acting under federal law include congressional committee investigators, Wheeldin v. Wheeler, 373 U.S. 647 (1963); the Deputy Attorney General of the United States, the First Assistant to the Assistant Attorney General, the Chief Executive of the Office of United States Marshals, and a Deputy United States Marshal, United States v. Faneca, 332 F.2d 872 (5th Cir. 1964), cert. denied, 380 U.S. 97 (1965), and Norton v. McShane, 332 F.2d 855 (5th Cir. 1964), cert. denied, 380 U.S. 981 (1965); agents of the Federal Bureau of Investigation, Sheridan v. Williams, 333 F.2d 581 (9th Cir. 1964); federal prison officials, Walker v. Blackwell, 360 F.2d 66 (5th Cir. 1966); and state agencies acting under federal law, Sigue v. Texas Gas Transmission Corp., 354 F.2d 40 (5th Cir. 1965) (per curiam). It has been held, however, that the District of Columbia is considered a "state" under the language of $\S 1983$. Sewell v. Pegelow, 291 F.2d 196 (4th Cir. 1961).

${ }^{208}$ In Dombrowski v. Burbank, 358 F.2d 821 (D.C. Cir. 1966) (per curiam), the argument was made that a United States Senator and the chief counsel for a senate committee had acted "under color of" state law by conspiring with state officials to violate plaintiffs' federal rights. The court held that, even assuming this to be true, the federal officials would be entitled to legislative immunity. Id. at 824 . The Supreme Court affirmed the granting of immunity to the Senator, but held the committee counsel had acted outside the scope of his duties. Dombrowski v. Eastland, 387 U.S. 82 (1967); note 130 infra and accompanying text. Although the court did not address itself to the collusion argument, it seems logical that federal officials not entitled to immunity could be held liable under $\S 1983$ for assisting in the enforcement of a state law.

Even though the court did not explicitly so state, Burbank impiles that a federal officer who acts under state law retains his official capacity, instead of becoming a private person, for purposes of asserting the defenses of immunity and comity to a $\$ 1983$ claim. Thus, the court ruled that the legislative officials could not have performed the acts which allegedly denied the federal rights of plaintiffs-issuing a subpoena for the documents once they were in the custody of the Louisiana officials-if they had been acting in a private capacity. Therefore, the court considered them to have acted as legislative officials, aud allowed them the defense of immunity. 358 F.2d at 826. 
this language was included in the statute in order to satisfy the "state action" requirement of the fourteenth amendment, private persons cannot be found liable unless their personal acts are sufficiently connected with "state action" to fulfill the "under color of" criterion. ${ }^{107}$

Generally, in suits against private persons, the requirement of sufficient connection with state authority demanded by the phrase "under color of" is not met. The existence of state laws and judicial machinery may provide the vehicle by which private persons are able to deprive others of federal rights. Nevertheless, in such instances, no liability has been found because the state is not considered to have taken an affirmative act which would create an appearance of state authority in the private person. ${ }^{108}$ For instance, private individuals who institute legal proceedings in courts provided by the state do not act "under color of" state law, even if by doing so they allegedly violate the federal rights of others. ${ }^{100}$ Similarly, private

${ }^{107}$ Until the criterion of "under color of" is satisfied, there can be no consideration of the defenses of official immunity or federal comity. Norton v. McShane, 332 F.2d 855 (5th Cir. 1964), cert. denied, 380 U.S. 981 (1965); Hoffman v. Halden, 268 F.2d 280, 298-301 (9th Cir. 1959), overruled on other grounds, Cohen v. Narris, 300 F.2d 24 (9th Cir. 1962). Furthermore, if private persons were deemed to have acted "under color of" state law, the immunity defense would not be available to them, for the underlying policies protected by immunity are not abridged unless a public official is involved. However, federal comity might restrain the issuance of an injunction against private persons in the limited situation where they were about to testify in state court proceedings. Cf. Stefanelli v. Minard, 342 U.S. 117 (1951).

${ }_{108}$ See cases cited notes 109-14 infra and accompanying text. The courts of appeals appear firmly to uphold the conclusion that the state must in some manner give the defendant the appearance of state authority before $\S 1983$ 's "under color of" language is satisfied. Few cases have discussed Shelley v. Kraemer, 334 U.S. 1 (1948) or Griffin v. Maryland, 378 U.S. 130 (1964), in conjunction with $\S 1983$ claims. In these cases, the Supreme Court ruled that the state's enforcement-through its police force or its courts-of private decisions to discriminate would constitute "state action." Although both cases may be read more narrowly, an expansive reading might cast doubt on many of the cases which hold actions of private persons not to be "under color of" state law. However, the Court of Appeals for the Second Circuit has distinguished Shelley in a $\$ 1983$ claim to enjoin a private civil action on the theory that before a state court decides the case, no state action is involved. Stevens v. Frick, 372 F.2d 378 (2d Cir. 1967).

${ }^{100}$ See, e.g., Kamsler v. M.F.I. Corp., 359 F.2d 752 (7th Cir. 1966) (creditor threatened to sue to collect a debt); Harris v. Turner, 329 F.2d 918 (6th Cir.), cert. denied, 379 U.S. 907 (1964) (father sues to gain custody of child from mother); Kinney v. Johnson, 319 F.2d 123 (5th Cir. 1963) (per curiam) (wife swore out warrant against husband); Skolnick v. Martin, 317 F.2d 855 (9th Cir.), cert. denied, 375 U.S. 908 (1963) (defendant required plaintiff, a paraplegic, to sit for four hours in a straight chair while taking his deposition); O'Connor v. O'Connor, 315 F.2d 420 (5th Cir. 1963) (suit to enjoin the further administration of an estate). The State's furnishing a judicial forum is deemed insufficient state action in the $\S 1983$ context. See Stevens v. Frick, 
attorneys, in defending clients in criminal proceedings or representing parties to a civil suit, are not acting "under color of" state law, even though they are considered officers of the court.110 Furthermore, public officials are not "under color of" state authority if they deprive others of federal rights while acting in a private capacity. ${ }^{111}$

The application of the "under color of" phrase to corporations and private voluntary associations, which are viewed as "persons" in the context of section 1983,112 provides additional examples of lack of sufficient connection with state authority. The fact that corporations are granted charters by states does not provide a sufficient appearance of state authority to make them potential defendants under section 1983.113 The granting of a corporate charter is generally deemed a neutral, perfunctory action by the state. Furthermore, where a state has taken no affirmative action to promote racial segregation in restaurants, a private restaurant which operates on a segregated basis is not considered to function "under color of" state law. ${ }^{114}$

supra note 108; Skolnick v. Spolar, 317 F.2d 857 (7th Cir.), cert. denied, 375 U.S. 904 (1963).

${ }^{110}$ Meier v. State Farm Mut. Ins. Co., 356 F.2d 504 (7th Cir.) (per curiam), cert. denied, 385 U.S. 875 (1966); Schroeder v. Illinois, 354 F.2d 561 (7th Cir. 1965), cert. denied, 384 U.S. 972 (1966); Byrne v. Kysar, 347 F.2d 734 (7th Cir. 1965), cert. denied, 383 U.S. 913 (1966); Harris v. Turner, supra note 109; Skolnick v. Martin, supra note 109; Sarelas v. Porikos, 320 F.2d 827 (7th Cir. 1963), cert. denied, 375 U.S. 985 (1964); Cooper v. Wilson, 309 F.2d 153 (6th Cir. 1962).

${ }^{111}$ See Screws v. United States, 325 U.S. 91, 111 (1945); note 45 supra and accompanying text. In Duzynski v. Nosal, 324 F.2d 924 (7th Cir. 1963), a clerk of court signed a petition for commitment of the plaintiff to a mental institution. However, no legally-imposed duty required him to sign as clerk. Therefore, the Court of Appeals for the Seventh Circuit held him not liable because he was deemed to have signed in a private capacity. See, in addition, Byrne v. Kysar, supra note 110; Joyce v. Ferrazzi, 323 F.2d 931 (lst Cir. 1963).

1121 U.S.C. $\$ 1$ (1964): "In determining the meaning of any Act of Congress, unless the context indicates otherwise ... the words 'person' and 'whoever' include corporations, companies, associations, firms, partnerships, societies, and joint stock companies, as well as individuals ...." Neither the langnage nor the legislative history of $\$ 1983$ indicates that "person" as used therein had a meaning different from that spelled out in 1 U.S.C. $\S 1$ (1964). See, e.g., Smith v. Hampton Training School for Nurses, 360 F.2d 577 (7th Cir. 1966); Williams v. Howard Johnson's Inc., 323 F.2d 102 (4th Cir. 1963).

${ }^{113}$ E.g., Rosee v. Board of Trade, 311 F.2d 524 (7th Cir.), cert. denied, 374 U.S. 806 (1963); see Saier v. State Bar, 293 F.2d 756 (7th Cir.), cert. denied, 368 U.S. 947 (1961).

Mr. Justice Douglas has argued, however, that the granting of a corporate chartcr or license would be sufficient "state action" to satisfy both the fourteenth amendment and the "under color of" language of $\$ 1983$. See Lombard v. Louisiana, 373 U.S. 267, 274 (1963) (Douglas, J., concurring).

114 Williams v. Howard Johnson's Inc., 323 F.2d 102 (4th Cir. 1963); see Williams 
In certain instances, however, the actions of private persons, including corporations and private associations, ${ }^{115}$ will have sufficient state connection so that the private person will be deemed to have acted "under color of" state law. For example, where a private hospital obtained the financial assistance of the state, the actions of the hospital in depriving its employees of federal rights were considered to be "under color of" state law. ${ }^{116}$ Furthermore, United States $v$. Price $^{117}$ provides a recent example of the manner in which the acts of private persons may be brought within the outer circle governed by the "under color of" phrase. In Price an action based on the criminal counterpart of section $1983^{118}$ was brought against a sheriff and several private citizens, who had acted jointly with him in depriving the victim of life without due process. ${ }^{119}$ The Supreme Court, in reversing a dismissal of the prosecution against the private persons, ${ }^{120}$ held that private persons who are "willful participant[s]

v. Hot Shoppes, Inc., 293 F.2d 835 (D.C. Gir. 1961), cert. denied, 370 U.S. 925 (1962). In the Howard Johnson decision, the Court of Appeals for the Fourth Circuit found that evidence that the Virginia Supreme Court had held there was no state policy of segregation in restaurants was sufficient to show a lack of "state action." Of course, under the public accommodations section of the Civil Rights Act of 1964, 78 Stat. 243, 42 U.S.C. $\$ 2000$ (a) (1964), the decision would have been different. Furthermore, the Howard Johnson result may be questioned on the theory that a long-standing popular custom of restaurant segregation would fall within the provision of $\$ 1983$ relating to a deprivation "under color of any . . . custom, or usage of any state." Cf. Lombard v. Louisiana, supra note 113.

${ }^{115}$ For cases involving $\$ 1983$ claims against individuals, see Wallach v. Cannon, 357 F.2d 557 (8th Gir. 1966); Cole v. Smith, 344 F.2d 721 (8th Gir. 1965); Winkler v. Pringle, 324 F.2d 613 (3d Cir. 1963), cert. denied, 377 U.S. 908 (1964); notes 109-11 supra and accompanying text.

For cases brought against corporations and voluntary associations, see Kamsler v. M.F.I. Corp., 359 F.2d 752 (7th Cir. 1966); Locum v. Atlantic Nat'l Bank, 354 F.2d 51 (5th Cir. 1965), cert. denied, 385 U.S. 898 (1966); Kamsler v. Chicago Am. Pub. Co., 352 F.2d 57 (7th Cir. 1965); Seeley v. Brotherhood of Painters, 308 F.2d 52 (5th Cir. 1962); notes 113-14 supra and accompanying text.

${ }^{110}$ Smith v. Hampton Training School for Nurses, 360 F.2d 577 (7th Cir. 1966); cf. Eaton v. Grubbs, 329 F.2d 710 (4th Cir. 1964). The holdings in these cases rest on a theory similar to that in Burton v. Wilmington Parking Authority, 365 U.S. 715, 722 (1961).

117383 U.S. 787 (1966).

${ }_{118} 18$ U.S.C. $\$ 242$ (1964); see note 38 supra for the text of this statute.

110 The murder was the product of a plot whereby the sheriff released the victims from custody, and subsequently, with the help of defendants (private citizens), intercepted and murdered them. 383 U.S. at 790 . See Marland v. Heyse, 315 F.2d 312 (10th Cir. 1963), for an example of a case in which joint action was not sufficient to impose liability under $\$ 1983$.

${ }^{120}$ The sheriff was convicted in the district court and did not appeal. 383 U.S. at $792-93$. 
in joint activity, with the state or its agents" are deemed to have acted "under color of" law.121

Although Price tends to expand the outer circle of potential defendants by including private persons engaged in joint activity with state officials, it seems unlikely that private persons will be held liable with any degree of frequency. Few private acts upon which section 1983 complaints are based are deemed to have sufficient state connection. 122 Indeed, in order to satisfy the "under color of" requirement, lower federal courts are likely to demand a showing of both a strong state connection, such as "wilful" participation, and a substantial need for the relief sought under section $1983 .{ }^{123}$ Such

121 The Price Court concluded that "private persons, jointly engaged with state officials in the prohibited action, are acting 'under color' of law for the purposes of the statute. To act 'under color' of law does not require that the accused be an officer of the state. It is enough that he is a willful participant in joint activity, with the state or its agents." 383 U.S. at 794. In United States v. Lester, 363 F.2d 68 (6th Cir. 1966), cert. denied, 385 U.S. 1002 (1967), the Court of Appeals for the Sixth Circuit upheld the conviction of a private citizen who had induced three innocent and unknowing police officers to perform acts which constituted violations of federal rights of another. Because the court relied on construction of the peculiar language of $\$ 242$ for its decision, the case is distinguishable from a similar case which might have been brought under $\S 1983$. However, Lester does illustrate the ease by which the phrase "under color of" may be read to include private persons. For instance, it seems possible that a private person who signs a warrant for the arrest of another in bad faith might be deemed to have acted "under color" for purposes of $\$ 1983$, even thougl there was no joint plan between him and the police.

The outermost extension of "state action" to encompass private persons is found in United States v. Guest, 383 U.S. 745 (1966). Six private individuals were charged under 18 U.S.C. $\$ 241$ (1964) with conspiring to deny Negroes of their right to equal access to state-owned facilities "by causing the arrest of Negroes by means of false reports that such Negroes had committed criminal acts." Id. at 747-48 n.1. In reversing a dismissal of the complaint for further hearings, the Court asserted that proof of "active connivance by agents of the State in the making of "false reports'" might be shown, which would satisfy the state action requirement. Id. at 756. However, a majority of the members of the Court believed that $\$ 241$ could be the basis for a conviction of private individuals even if there were no state connivance in the con. spiracy. Their theory was that $\S 5$ of the fourteenth amendment empowered Congress to enforce the equal protection clause-regardless of whether there was any state action -if state-owned facilities were involved. Id. at 762, 777-81. For a discussion of $\$ 241$, see Feuerstein, Civil Rights Crimes and the Federal Power to Punish Private Individuals for Interference with Federally Secured Rights, 19 VAND. L. REv. 641 (1966).

${ }^{122}$ A survey of cases since the Monroe decision reveals that only one out of seventeen cases brought against private persons under $\S 1983$ has been successful. See Smith v. Hampton Training School for Nurses, 360 F.2d 577 (4th Cir. 1966).

${ }^{123}$ When an injunction under $\S 1983$ is sought, the plaintiff must show evidence of harm or potential harm amounting to irreparable injury. Douglas v. City of Jeannette, 319 U.S. 157 (1943), notes 83-86 supra and accompanying text; see Dombrowski v. Pfister, 380 U.S. 479 (1965), note 86 supra. Recovery of damages under $\$ 1983$ requires the same proof of harm as is necessary in ordinary tort cases. For a discussion of the applicable tort rules, see PROsser, TorTs $\$ 30$ (3d ed. 1964). 
a result is consistent with the view that the fourteenth amendment, which section 1983 purports to enforce, should not negative state authority by applying federal sanctions directly against private persons. ${ }^{124}$

\section{Legislators}

There is little doubt that state legislators sued under section 1983 are acting "under color of" state law when performing their legislative duties. Therefore, the chief determinant of section 1983 liability is whether or not legislators are within the inner circles of official immunity or of federal comity. Democratic opponents of the Third Enforcement Act recognized that the language "every person" was broad enough to encompass state legislators within the outer circle of "under color of" state law and strongly objected to their potential liability. ${ }^{125}$ Although the Democrats did not mention the doctrine of official immunity, they employed the doctrine's traditional justification in opposing legislative liability: "liability would be utterly destructive of the freedom of thought and action that are indispensable to the proper discharge of legislative duties." ${ }^{126} \mathrm{Re}$ publican proponents of the 1871 Act did not respond to this criticism.

Eighty years later in Tenney, the Supreme Court acknowledged the validity of the Democrats' objections and ruled that official immunity did extend to legislators as "discretionary" officials when sued for damages under section 1983.127 Subsequent federal court cases have been consistent with the Tenney decision, ${ }^{128}$ as well as with

\footnotetext{
124 See note 71 supra and accompanying text.

${ }^{125}$ Senator Thurman of Ohio found the possible liability of legislators under the predecessor of $\S 1983$ particularly disturbing: "[I]f the legislators of a State pass a law which, in the judgment of some person, deprives him of some right . . . and a district judge ... should be of the same opinion .... where is the clause that exempts those legislators from the action that is provided for in [the predecessor of $\$ 1983]$... ? [B]y the terms of this bill, unlimited as they are, every legislator who votes for such a law is liable to be sued in a district court . . . " Cong. Globe, 42d Cong., lst Sess. app. 217 (1871) [covering 1833-1873]. See, e.g., $i d$. at 365-68 (remarks of Representative Arthur).

${ }^{120} I d$. at app. 217 (remarks of Senator Thurman).

${ }^{127}$ See notes 59-66 supra and accompanying text.

${ }^{128}$ Since the Monroe decision, only two cases brought against legislators under $\S 1983$ have sought damages. In Wheeldin v. Wheeler, 373 U.S. 647 (1963), the Supreme Court dismissed a claim against a congressional committee investigator on the theory that he was acting under federal law and therefore not amenable to suit under $\$ 1983$. $I d$. at 650 . Furthermore, the Court found that "no general statute making federal officers liable for acts committed 'under color' but in violation, of their federal authority has been passed." Id. at 652. However, the Court noted in dictum that the immunity defense would liave been applicable had he been acting within the
} 
Stefanelli, which broadly stated the rule of federal comity. ${ }^{120}$ Thus, in the recent case of Dombrowski v. Eastland, ${ }^{130}$ plaintiffs alleged that defendants, a United States Senator and the chief counsel of a Senate subcommittee, had acted "under color of" state law by colluding with Louisiana officials in illegally searching plaintiffs' offices and seizing their documents. ${ }^{131}$ The Supreme Court affirmed the dismissal of the complaint against the defendant Senator on the basis of legislative immunity, stating that "it is the purpose . . . of legislative immunity . . . that legislators engaged 'in the sphere of legitimate legislative activity' . . . should be protected not only from the consequences of litigation's results but also from the burden of defending themselves." ${ }^{132}$ However, as regards the complaint

scope of his duties. Id. at 651 . The second suit in which damages were sought is Dombrowski v. Eastland, 387 U.S. 82 (1967), discussed in notes 130.34 infra and accompanying text. Both cases also involved prayers for injunctive relief, which were denicd. See note 132 infra.

${ }^{229}$ For a discussion of federal comity and the Stefanelli decision, see notes 83.86 supra and accompanying text.

In Dombrowski v. Pfister, 380 U.S. 479 (1965), and Jordan v. Futcheson, 323 F.2d 597 (4th Cir. 1963), injunctions were granted. In both cases, state legislators were sued under $\$ 1983$ for violations of federal rights by harassing plaintiffs, various civil rights organizations, with threats of prosecution. The Jordan court explained the formula which it applied to determine whether to issue injunctive relief against state legislators: "When the court does act under the fourteenth amendment, it must weigh the state's interest ... against the interest of the citizen in his constitutional rights. Only if the state's interest is overriding and compelling will the courts condone an invasion of those rights for which the plaintiffs here seek relief." 323 F.2d at 600. As explained in Pfister, see note 86 supra, intentional harassment to deprive citizens of riglits before trial will override the presumption, based on respect for a federal-state balance, that "state courts and prosecutors will observe constitutional limitations as expounded by this Court, and that the mere possibility of erroneous initial application of constitutional standards will usually not amount to irreparable injury" which would justify injunctive relief. 380 U.S. at $484-85$

130387 U.S. 82 (1967) (per curiam).

${ }^{131}$ The Court evidently assumed that the defendant federal officers would fall within the statutory criterion of acting "under color of" state law if they were shown to have actually colluded with the Louisiana officials in carrying out the illegal search and seizure. See note 106 supra and accompanying text.

132387 U.S. at 84 . The Court found that the doctrine of legislative immunity lad its roots in the "speech and debate" clause of the Constitution (U.S. CoNST. art. 1, $\$ 6$, cl. 2), as explained in Tenney v. Brandhove, 341 U.S. 367,376 (1951) and Kilbourn v. Thompson, 103 U.S. 168, 204 (1880).

Plaintiffs in Eastland sought injunctive relief as well as damages. However, the Court of Appeals for the District of Columbia refused to issue an injunction against the defendants because it could not be enforced effectively against them to prevent harm to the plaintiffs. Thus, the court reasoned that the committee itself, which would not be bound by the injunctive order, could continue to withhold planitiffs' documents. Furthermore, the court was attempting to maintain the principle of separation of powers among coordinate branches of the federal government, an approach analogous 
against the subcommittee counsel, the Court remanded the case for trial. While acknowledging the applicability of immunity to legislative employees, the Court asserted that the doctrine provided a greater degree of protection for the legislators themselves than for employees of the legislative body. ${ }^{133}$ Therefore, the Court deemed the evidence sufficient to withstand the defendant subcommittee counsel's motion for summary judgment. ${ }^{134}$

The extension of the inner circles of immunity and comity to legislators sued under section 1983 seems highly desirable. Since there is little question that legislators are "discretionary" officials, the reasons supporting immunity in the traditional sense of protecting independent decision-making seem persuasive. Furthermore, the continuing desire to maintain the self-confidence of state governments, of which state legislators are the chief law-makers, is given expression by the application of federal comity. Moreover, as few violations of federal rights result from the actions of legislators, ${ }^{135}$ the

to the doctrine of comity. Dombrowski v. Burbank, 358 F.2d 821,824 (D.C. Cir. 1966).

133387 U.S. at 85.

181 "There is controverted evidence in the record, such as the date appearing on certain documents which respondents' evidence disputes as a typographical error, which affords more than merely colorable substance to petitioners' assertions as to respondent Sourwine [subcommittee counsel] . . . [W] [Welieve that, against an employee of the committee, this showing is sufficient to entitle petitioners to go to trial." Id. at 84 .

${ }^{135}$ Since Monroe increased the scope of rights protected by $\S 1983$, only five suits against state legislators alleging individual harm have reached the federal appellate level. See notes 128-29 supra; cf. Ivey v. Frost, 346 F.2d 115 (8th Cir. 1965). This represents the smallest number of $\S 1983$ cases brought against any of the categories of state officials considered in this comment.

Of course, by the enactment of an unconstitutional state law, state legislators may theoretically infringe the federal rights of a great number of persons. Malapportionment of state legislatures is an example. However, this comment does not deal with the cumulative rights of an entire population. Instead, whenever the number of federal rights violated is mentioned, reference is to individual personal rights which may be deprived by the "tortious" actions of state officials directed expressly at the individual plaintiff. This distinction may be justified on the theory that when the rights of a large segment of the population are affected, the political process offers an adequate remedy, and on the ground that $\$ 1983$ historically has been a tool for the vindication of individual federal rights.

Nevertheless, it should be noted that $\S 1983$ has been the basis for several of the historic reapportionment cases. See Roman v. Sinock, 377 U.S. 695 (1964); Davis v. Mann, 377 U.S. 678 (1964); WMCA, Inc. v. Lomenzo, 377 U.S. 633 (1964); Reynolds v. Sims, 377 U.S. 533 (1964); Baker v. Carr, 369 U.S. 186 (1962). These decisions resulted in injunctions and other equitable relief against various state officials in an effort to remedy the denial of equal protection caused by malapportionment. In these cases the Court did not discuss the elements of a $\$ 1983$ claim. However, it could 
importance of maintaining full legislative freedom of discussion would appear to outweigh greatly the competing need to provide redress for violations of federal rights.

\section{City Councils, School Boards, and Their Members ${ }^{136}$}

Multi-member councils and boards which make and administer local state regulations have many of the characteristics of state legislatures. Like legislators, members of boards and councils are clearly acting "under color of" state law when executing their "discretionary" duties. Therefore, the chief question in determining their liability in damages under section 1983 is whether the inner circle created by official immunity encompasses members of boards and councils. ${ }^{137}$ When an injunction is sought, the inquiry is whether federal comity extends its protection to the typical functions of boards and councils. ${ }^{138}$

Prior to the Monroe decision, the doctrine of immunity as it relates to section 1983 suits against members of boards and councils was articulated by the Court of Appeals for the First Circuit in Cobb v. City of Malden. ${ }^{139}$ The defendants in Cobb-the mayor and members of the board of aldermen-were acting as legislators in preventing the appropriation of funds to pay the salaries of plaintiff teachers. In response to a charge that plaintiffs had thus been de-

be said that the Court found "irreparable injury," based on the fact that no other mode of relief-political or judicial-was available against malapportionment.

${ }^{186}$ For purposes of this comment, state election and civil service hoards, city councils, school boards, and their members have been grouped together. They occupy similar positions in the hierarchy of governmental organizations, all being midway between state officials charged with making overall state policy and local sheriffs and policemen. Furthermore, all make their decisions as groups, with no one individual member having power independent of the group. Finally, the same rules for determining liability under $\$ 1983$ apply with equal force to each of these state organizations.

In ordinary tort suits, these officials are accorded a qualified privilege from damages suits if they execute their duties in good faith. See Prosser, TorTs $\$ 126$ (3d ed. 1964).

${ }^{132}$ Senator Thurman, a Democratic opponent of the Third Enforcement Act, made the sole reference in the legislative history to the possible liability in damages of a group which falls within the category of boards and councils: "[I]f any school directors should provide schools for the colored children separate from the whites and not allow them to mix together, that would be, in [Senator Sumner's] . . . opinion, a deprivation of the right of the colored child." Cong. Globe, 42d Cong., 1st Sess. app. 217 (187I) [covering 1833-1873]. The Senator's remarks were intended to show the allegedly unwarranted breadth of the statute in a time when schools were for the most part privately operated. However, his statement takes on added significance today, when many schools are administered by the states.

${ }^{138}$ See notes 72 supra and 153 infra.

${ }^{130} 202$ F.2d 701 (1st Cir. 1953) (Magruder, J, concurring). 
prived of property without due process, the defendants were found to have "a qualified privilege, giving them a defense against civil liability for harm caused by acts done by them in good faith in the performance of their official duty as they understood it."140 Monroe effectively removed the "qualified privilege" by rejecting the rule that an intention to deprive others of rights was necessary to establish a section 1983 due process claim. ${ }^{141}$ However, lower federal courts subsequently adopted a new criterion which diminished the harshness of a literal application of section 1983 to boards and councils. This newly created standard, applicable in suits for either damages or injunction, could appropriately be called the rule of reasonable discretion: ${ }^{142}$ if the particular board-council decision rationally relates to a valid administrative purpose and outweighs the need for civil redress provided by section 1983, the decision is said to have been made with "reasonable discretion," and no liability results. ${ }^{143}$

The rule of reasonable discretion, the application of which depends upon an evaluation of the circumstances surrounding a

${ }^{140} I d$. at 707. To be held liable, the defendants must have "realized they were subjecting plaintiff to harm." Ibid. This statement suggests that the "qualified privilege" of boards and councils depended ultimately on the absence of an intention to deprive others of federal rights.

111 See notes 99-100 supra and accompanying text. The recent case of Pierson v. Ray, 386 U.S. 547 (1967), seems to add further indicia that good faith alone is not enough. Thus, Pierson held that "good faith and probable cause" was a sufficient defense against a $\$ 1983$ complaint. See notes 281-90 infra and accompanying text.

142 See, e.g., Chambers v. Hendersonville City Bd. of Educ., 364 F.2d 189 (4th Cir. 1966); Johnson v. Branch, 364 F.2d 177 (4th Cir. 1966), cert. denied, 385 U.S. 1003 (1967); Burnside v. Byars, 363 F.2d 744 ( 5 th Cir. 1966); Mosher v. Beirne, 357 F.2d 638 (8th Cir. 1966); Jenson v. Olson, 353 F.2d 825 (8th Cir. 1965); Hopkins v. Wasson, 329 F.2d 67 (6th Cir.), cert. denied, 379 U.S. 854 (1964); Daly v. Stratton, 326 F.2d 340 (7th Cir. 1964). Lower federal courts have not denominated their treatment of cases against boards and councils as resting on a rule of reasonable discretion. That label is employed herein because it is most descriptive of the test which the courts seem to apply.

${ }_{143}$ The rule of reasonable discretion as applied to damage suits under $\$ 1983$ against boards and councils seems identical to the standard used to determine whether an injunction based on $\$ 1983$ should issue against these state officials. Just as the standard for winning damages has been relaxed in the case of councils and boards, so has the Douglas.Stefanelli formula for injunctive relief. See notes 80-86 supra and accompanying text. Therefore, less clear and convincing evidence of irreparable injury is necessary to overcome the presumption in favor of maintaining the federal-state balance. One reason the standard for federal injunctive relief is relaxed when boards and councils are sued is their lower rank in the governmental hierarchy. Thus, there seems less danger of inflaming the federal-state balance when they are enjoined. In any event, when either injunctions or damages are sought, the lower federal courts seem to be applying a rule of reasonable discretion to determine liability. Therefore, in treating recent developments, suits for both kinds of $\$ 1983$ relief will be considered together. 
particular decision, has been employed in cases arising in four areas of board-council activity. In the area of regulation-making-the most truly legislative of all board-council functions-liability under section 1983 will not attach where the board-council decision promotes a valid administrative interest, notwithstanding the alleged infringement of a federal right. For example, a school board policy forbidding the wearing of "freedom buttons" was upheld against a section 1983 claim for injunctive relief, despite the fact that the policy might have inhibited freedom of expression. ${ }^{144}$ In that case, however, evidence that "freedom buttons" caused disturbances in the school and undermined the school routine demonstrated a valid administrative justification. In a similar case where no such evidence was introduced, the court enjoined the enforcement of the ban on "freedom buttons." 145

A second area of board-council functions involves personnel selection and removal. Although the theory is well established that there is no right to public employment, ${ }^{146}$ damages and injunctive relief based on section 1983 may be obtained if the board or council fails to renew an employment contract or removes a person from office without exercising "reasonable discretion."147 Generally, removal or failure to renew contracts will be deemed unreasonable if the reason for dismissal is not rationally related to the purposes which the board or council may validly pursue. Thus, removal because of the exercise of a valid right while not engaged in functions related to employ-

\footnotetext{
144 Blackwell v. Issaquena Co. Bd. of Educ., 363 F.2d 749 (5th Cir. 1966).

${ }^{145}$ Burnside v. Byars, 363 F.2d 744 (5th Gir. 1966); cf. Kelly v. Page, 335 F.2d 114 (5th Cir. 1964).

${ }^{140}$ E.g., Slochower v. Board of Higher Educ., 350 U.S. 551 (1956) (dicta); Jolinson v. Branch, 364 F.2d 177 (4th Cir. 1966), cert. denicd, 385 U.S. 1003 (1967); Jenson v. Olson, 353 F.2d 825 (8th Cir. 1965). The theory that there is no right to public cmployment is subject to many qualifications today. See Garrity v. New Jersey, 385 U.S. 493 (1967); Spevack v. Klein, 385 U.S. 511 (1967); Slochower v. Board of Higher Educ., supra; Wieman v. Updegraff, 344 U.S. 183 (1952). For an interesting article suggesting that government largesse, of which public employment is a part, is becoming the "property" of today, see Reich, The New Property, 73 YaLE L.J. 732 (1964).

${ }^{147}$ See, e.g., Birnbaum v. Trussell, 37I F.2d 672 (2d Cir. 1966) (damages found); Smith v. Board of Educ., 365 F.2d 770 (8th Cir. 1966) (injunction against board granted); Chambers v. Hendersonville City Bd. of Educ., 364 F.2d 189 (4th Cir. 1966) (court order against board issued); Branford v. School Dist. No. 20, 364 F.2d 185 (4th Cir. 1966) (injunction denied); Johnson v. Branch, supra note 146 (injunction and damages granted); Jenson v. Olson, supra note 146 (damages denied); Hopkins v. Wasson, 329 F.2d 67 (6th Cir.), cert. denied, 379 U.S. 854 (1964) (damages denied). Section 1983 is not available as a means for plenary review of the dismissal on the merits. See Frazier v. East Baton Rouge Parish School Bd., 363 F.2d 861 (5th Cir. 1966).
} 
ment has been held unreasonable and arbitrary. ${ }^{148}$ However, if the board or council demonstrates that the person removed from office had actually disrupted the valid programs and policies of the board while exercising his right during employment, the removal will be deemed an exercise of "reasonable discretion."149

The issuance of business licenses is a third board-council function which may result in liability under section 1983 if the exercise of discretion in refusing the license is unreasonable. For example, a board which allegedly has not followed due process standards in conducting a licensing hearing will be said to have acted unreasonably in denying the particular license application. ${ }^{\mathbf{1 5 0}}$ A final category of board functions involves admissions of persons to schools. When the basis of a section 1983 claim in this area is racial discrimination, courts are quick to issue injunctions. Again the theory is that decisions resting on unconstitutional factors are not generally rationally connected to any valid administrative purpose. ${ }^{151}$

The replacement of both the "qualified privilege" and a strict view of federal comity with a rule of reasonable discretion as the test to determine section 1983 liability for boards and councils has produced a significant change. On the one hand, if a defendant board or council could avail itself of either immunity or comity, the court would dismiss the section 1983 claim before examining the process of board-council decision-making. In this situation, knowledge that

\footnotetext{
${ }^{148}$ E.g., Johnson v. Branch, supra note 147 at 181-82. The Court of Appeals for the Fourth Circuit found in Johnson that the defendant school board had not renewed the employment contract of an otherwise quahified teacher primarily because she had participated in demonstrations for Negro equality. Dismissal "without a procedure calculated to determine whether legitimate grounds do exist" is unreasonable. Birnbaum v. Trussell, supra note 147 , at 678 .

${ }^{149}$ Jenson v. Olson, 353 F.2d 825, 828 (8th Cir. 1965). In Jenson the plaintiff had criticized the state agency and its administrators, for which he worked. In dismissing his $\S 1983$ suit against these defendants, the court said that although plaintiff possessed the first amendment right of freedom of speech, that gave him no right to disrupt and reduce department efficiency with impunity. Therefore, his removal from office was "reasonable."

${ }^{150}$ See, e.g., Azar v. Allen, 336 F.2d 1022 (5th Cir. 1964); Hornsby v. Allen, 326 F.2d 605 (5th Cir. 1964); cf. Marshall v. Sawyer, 301 F.2d 639 (9th Cir. 1962). For cases in which the denial of business licenses was effected with "reasonable discretion," see, e.g., Wallach v. City of Pagedale, 359 F.2d 57 (8th Cir. 1966); Mosher v. Beirne, 357 F.2d 636 (8th Cir. 1966); Daly v. Stratton, 326 F.2d 340 (7th Gir. 1964).

${ }^{151}$ See, e.g., Hightower v. McFarland, 355 F.2d 468 (5th Cir. 1966); Lee v. Hodges, 321 F.2d 480 (4th Cir. 1963); Oklahoma High School Athletic Ass'n v. Bray, 32l F.2d 269 (10th Cir. 1963); Reed v. Pearson, 306 F.2d 690 (5th Cir. 1962); Meridith v. Fair, 298 F.2d 696 (5th Cir.), cert. denied, 371 U.S. 828 (1962).
} 
the court would look no further would have a deterrent effect on persons who might bring suits against officials within the inner circles of nonliability. On the other hand, under the rule of reasonable discretion, the court fully examines the basis of the board-council decision before determining ultimate liability under section 1983. This approach produces closer and more frequent federal court surveillance of boards and councils. Nevertheless, the use of the rule of reasonable discretion in lieu of immunity and comity in the boardcouncil area appears proper when the reasons justifying the two doctrines in the context of section 1983 are considered. The traditional rationale for official immunity-to protect the independent judgment of policy-makers-has never appeared convincing when applied to city councils and school boards, which rank far down the hierarchy of governmental decision-makers. ${ }^{152}$ Also, there is less need for an extension of comity to board-council functions, for it seems reasonable that occasional federal suits under a rule positing broad discretion in the local agencies are unlikely to cause serious federalstate friction..$^{153}$

Judges

After the Monroe decision broadened the scope of rights protected by section $1983,{ }^{154}$ suits against state judges-from the state supreme court level to police magistrate-showed a marked increase. ${ }^{155}$ As officials of a state's judicial system, judges are clearly within the outer circle of potential defendants delineated by the phrase "under color of." Therefore, the dispositive question has been whether judges are within the inner circle of official immunity. ${ }^{160}$ In every

\footnotetext{
${ }^{152}$ In fact, in most states, boards and councils are not accorded complete insulation of absolute immunity, but merely a qualified privilege which protects them from suit if they act in good faith. See Prosser, TORTs \$ 126 (3d ed. 1964).

${ }^{153}$ The purpose of comity is to mitigate conflicts between the state and fcderal governments. See note 73 supra and accompanying text. The greatest friction arises whenever the federal government interferes with a state function which the state considers essential to its sovereignty and independence. It is widely recognized that a state's own administration of its laws is such an incident of sovereignty. However, it seems unlikely that a state would insist that individual federal "tort" suits arising from the decisions of local city governments or from the removal of a city employee would be a violation of its sovereignty. Cf. notes 72,138 supra.

${ }^{154}$ See notes $99 \cdot 100$ supra and accompanying text.

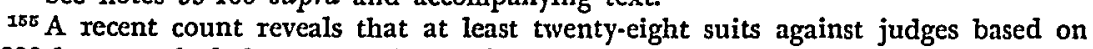
$\S 1983$ have reached the courts of appeals since the Monroe decision in 1961 .

${ }^{168}$ Since most alleged violations of federal rights by state judges occur during the course of trial, both 28 U.S.C. $\$ 2283$ (1964) and the doctrine of federal comity
} 
case, the well-established rule of judicial immunity from damages has been affirmed. ${ }^{157}$

During the congressional debates over the predecessor of section 1983, judges received more attention than any other state official..$^{158}$ Democratic opponents of the Third Enforcement Act critically pointed to the possible liability of judges under the broad, inclusive language of section 1983.158 Statements by Republican sponsors re-

described in Douglas and Stefanelli clearly apply. See notes 73-86 supra and accompanying text. Therefore, few $\S 1983$ claims for injunctive relief are brought against judges. See Marshali, Federalism and Civil Rights 53 (1964). In view of this fact, no further discussion of federal comity as applied to judges appears necessary. Cases in which federal comity has protected judges and other court officials from injunction include Stevens v. Frick, 371 F.2d 378 (2d Gir. 1967); Hall v. New York, 359 F.2d 26 (2d Cir.), cert. denied, 385 U.S. 879 (1966); Corsican Prods. v. Pitchess, 338 F.2d 441 (9th Cir. 1964); Wood v. Vaughan, 321 F.2d 480 (4th Cir. 1963); Wojcik v. Palmer, 318 F.2d 171 (7th Cir.), cert. denied, 375 U.S. 930 (1963); Goss v. Illinois, 312 F.2d 257 (3d Gir. 1963); Gately v. Sutton, 310 F.2d 107 (10th Cir. 1962); Dronet v. Tucker, 300 F.2d 559 (5th Cir. 1962).

${ }^{167}$ See, e.g., Pierson v. Ray, 386 U.S. 547 (1967); Carmack v. Gibson, 363 F.2d 862 (5th Cir. 1966); Bauers v. Heisel, 361 F.2d 581 (3d Cir. 1966), cert. denied, 386 U.S. 1021 (1967) (dicta); Gabbard v. Rose, 359 F.2d 182 (6th Cir. 1966); Haldane v. Chagnon, 345 F.2d 601 (9th Cir. 1965); Arnold v. Bostick, 339 F.2d 879 (9th Cir. 1964), cert. denied, 382 U.S. 858 (1965); Harman v. Superior Court, 329 F.2d 154 (9th Cir. 1964); Sires v. Cole, 320 F.2d 877 (9th Cir. 1963); Gately v. Sutton, 310 F.2d 107 (10th Cir. 1962); Stift v. Lynch, 267 F.2d 237 (7th Cir. 1959); Tate v. Arnold, 223 F.2d 782 (8th Cir. 1955); Francis v. Crafts, 203 F.2d 809 (1st Cir. 1953). Spires v. Bottorff, 317 F.2d 273 (7th Cir. 1963), cert. denied, 379 U.S. 938 (1964), is the only recent case in which a judge has been held liahle in damages under $\$ 1983$. However, the court affirmed rather than rejected the rule of judicial immunity. Liability rested on the fact that the judge had acted "with clear absence of" jurisdiction by inducing a prison official to prevent plaintiff from corresponding with the clerk of the court concerning lis appeal. Therefore, the judge had not met the requisite of judicial immunity that he be acting "within the scope of his duties." See notes 53-55 supra and accompanying text.

${ }^{188}$ See, e.g., Cong. GLOBE, 42d Cong., lst Sess. 366 (1871) [covering 1833-1873] (remarks of Representative Arthur); id. at 385 (remarks of Representative Lewis); id. at 486 (remarks of Representative Cook); id. at app. 185 (remarks of Representative Platt); id. at app. 216-17 (remarks of Senator Tluurman); id. at app. 276-77 (remarks of Representative Porter).

${ }^{180}$ Democratic Representative Arthur stated: "Hitherto, in all the history of this country, and of England, no judge or court has been held liable, civilly or criminally for judicial acts .... Under the provisions of [\$ 1983's progenitor] . . . every judge in the State court and every other officer thereof ... will enter upon and pursue the call of official duty with the sword of Damocles suspended over him by a silken thread ...." Id. at 366. According to Democratic Representative Lewis, "by the [predecessor of $\$ 1983]$... the judge of a State court, though acting under oath of office, is made liable to a suit in the Federal court and subjected to damages for his decision against a suiter, however honest and conscientious that decision may be." Id. at app. 385 . Senator Thurman expressed the Democratic criticism in the interrogative form: "Is the old maxim of the law, that a judge for any judgment he gives can only be liable to impeachment, to be reversed and that judge dragged to a Federal court to be mulcted in damages if the Federal judge, no wiser than he, under no higher obligation to obey the Constitution than he, shall be of a different opinion?" Id. at app. 217. 
garding the failure of state courts in the South to provide equal justice were calculated to show the need for a federal remedy. ${ }^{100}$ Thus, they offered no direct rebuttal to specific Democratic criticism. Nevertheless, Republican explanations of section 1983's predecessor furnish some inferential support for judicial immunity. Representative Porter, who favored the bill, felt that it would not reach-and was not intended to reach-the "outrages committed under the forms of law, and especially in the courts of the States ...."101 Although he did not specify whether perjured testimony, biased juries, or the judges themselves were responsible for the "legalized outrages,"102 it is reasonable to assume that Representative Porter felt that the actions of state judges were a significant factor. ${ }^{103}$ Therefore, a plausible

${ }^{100}$ Representative Platt gave the Republican view of justice in the South: "It has been a well-recognized . . . fact, that no Republican, white or black, especially if he is a citizen who has come here from another state or is at all prominent, can secure as plaintiff or defendant anything like equal justice before the courts of the State ... ." Id. at app. 185. See, e.g., id. at 334 (remarks of Representative Hoar); id. at 604-05 (remarks of Senator Pool); $i d$. at app. 78 (remarks of Representative Perry); id. at app. 277 (remarks of Representative Porter); id. at app. 312 (remarks of Representative Burchard); notes 11, 15, and 16 supra and accompanying text.

${ }^{161} \mathrm{Id}$. at 276-77. Thus, Representative Porter stated: "[T]here is yet another class of outrages which [the predecessor of $\S 1983$ ] ... does not reach, and it does not reach at all, and is not intended to reach. I refer to the outrages committed under the forms of law, and especially in the courts of the States which are in the hands of the Democratic party .... I would like to see a bill pass that would reach not only the $\mathrm{Ku}$ Klux outrages, but the other outrages, the legalized outrages . . . I" Ibid.

${ }^{182}$ According to Representative Stoughton, who presented to the House the report of the Senate investigating committee on conditions in the South, one of the main evils of the $\mathrm{Ku} \mathrm{Klux}$ Klan was "that it not only binds its members to execute decrees of crime, but protects them against conviction and punishment, first by disguises and secrecy, and second by perjury, if necessary, upon the witness-stand and in the jurybox." Id. at 320. Representative Hoar stressed the failure of southern juries to return impartial verdicts: "If the jurors of South Carolina constantly and as a rule refuse to do justice between man and man where the rights of a particular class of its citizens are concerned, and that State affords by its legislation no remedy ....," then the state has deprived that class of equal protection of the laws. Id. at 334; see id. at app. 78 (remarks of Representative Perry).

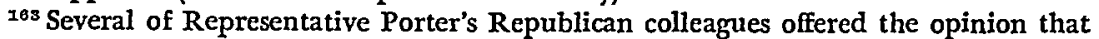
judges were a contributing cause of the breakdown of justice in the South. Representative Perry pointed out that "where these gangs of [Ku Klux Klan] assassins show themselves ... judges having ears to hear, hear not.... In the presence of these gangs all the apparatus and machinery of civil government, all the processes of justice, skulk as if government and justice were crimes and feared detection." $I d$. at app. 74. Republican Representative Sheldon explained the breakdown on the theory that judges in the South had fallen victim "to a mania which sometimes seizes hold of the popular mind." Id. at 368. According to Senator Osborn, "[I]f the state courts had proven themselves competent to suppress the local disorders, or to maintain law and order," Congress would not have had to legislate on this subject. Id. at 653. Representative Platt offered a specific example of a judge's denying equal justice and char- 
explanation of why he thought the progenitor of section 1983 did not reach the "legalized outrages" is that state judges who allowed such "outrages" to occur were protected from liability by judicial immunity. 104

These Republican statements were not specifically noted by the Court of Appeals for the Third Circuit in Picking $v$. Pennsylvania $R . R .{ }^{105}$ the first case to consider judicial immunity as a defense to a section 1983 claim for damages. Instead, the court found that "Congress by enacting the Civil Rights Act sub judice intended to abrogate the privilege [of judicial immunity] to the extent indicated by the act and in fact did so."166 However, when the Supreme Court in Tenney ruled that state legislators were immune from section 1983 suits, ${ }^{167}$ lower federal courts were quick to find a close analogy between legislative and judicial immunity based on the traditional notion that independence of judgment should be protected. ${ }^{168}$ In-

acterized the judges as "little kings, with almost despotic powers to carry out the partisan demands of the legislature which enacted them." Id. at app. 186.

104 Another proponent of the Third Enforcement Act, Representative Cook, added a further indicium that the statute was not intended to abrogate judicial immunity. In answer to a question as to whether the refusal of a state court to certify the record of a case to the Supreme Court would be a basis for liability, he answered:

"MR. Cook: If an attempt has been made to prevent a record being certified ... by force, intimidation, or threat, it would have been an act which the national Government might prohibit by law....

"Mr. ELDRIDGE: The state officers in the case I mention not only threatened not to do the act, but refused to do it, and did not do it.

"Mr. Cook: But they acted judicially; they did not propose to deprive a citizen of his right by violence. There was no force, intimidation, or threat." Id. at 486 . Thus, according to Representative Cook, state officials would not be liable under the predecessor of $\$ 1983$ if they "acted judicially."

${ }_{105}$ I5I F.2d 240 (3d Cir. 1945), cert. denied, 332 U.S. 776 (1947); notes 56-57 supra and accompanying text. Picking was subsequently discredited by the Supreme Court's decision in Tenney, see note 68 supra and accompanying text, and finally overruled by the Court of Appeals for the Third Circuit in Bauers v. Heisel, 361 F.2d 581 (3d Cir. 1966), cert. denied, 386 U.S. 1021 (1967).

$10015 \mathrm{I}$ F.2d at 250 .

${ }^{107}$ See notes 59.66 supra and accompanying text.

${ }^{108}$ In the first post-Tenney case involving judicial immunity, the Court of Appeals for the First Circuit held the doctrine to be a defense in $\$ 1983$ claims against judges, in spite of the Picking precedent. Francis v. Crafts, 203 F.2d 809, 811 (Ist Cir. 1953). Two years later, the Court of Appeals for the Eighth Circuit agreed, stating that the construction of $\S 1983$ so as not to abrogate judicial immunity was "based on sound considerations of public policy and practical necessity." Tate v. Arnold, 223 F.2d 782, 786 (8th Cir. 1955). Adopting the reasoning of Tenney, the court said: "The general language employed in the Civil Rights Act does not evidence a clear congressional intent to impair the long standing rule of judicial immunity." Ibid. This same view prevailed in the lower federal courts after the Monroe decision in 1961. Thus, in the words of Rhodes v. Houston, 202 F. Supp. 624, 629-30 (D. Neb.), affd, 309 F.2d 959 (8th Cir. 1962), cert. denied, 372 U.S. 909 (1963), "an examination of all federal 
deed, in the recent case of Pierson $v$. Ray, ${ }^{169}$ the Supreme Court reasoned that the doctrine of judicial immunity was as firmly established as immunity for legislators and dismissed a section 1983 damages claim on that basis. ${ }^{170}$ In Pierson, the defendant, a municipal police judge, had convicted plaintiffs, Negro and white clergymen, under a Mississippi breach of the peace statute which they allegedly violated by seeking to use a segregated bus station. ${ }^{171}$ When the statute was later held unconstitutional as applied to a similar factual situation, ${ }^{172}$ plaintiffs brought a damage suit under section 1983 against the judge and the arresting police officers, ${ }^{173}$ claiming their arrest and conviction under the invalidated law was a deprivation of due process "under color of" state law. Without examining the process of judicial decision-making leading to the convictions, the Supreme Court ruled that the defendant judge was absolutely immune from damages under section 1983.174 Writing for the Court, Mr. Chief Justice Warren stated that the public interest in "principled and fearless decision-making" by the judiciary required the protection of official immunity, especially when judges have to decide "controversial cases which arouse the most intense feelings in litigants."175 Furthermore, the Court reaffirmed the Tenney interpretation that Congress, by adopting section 1983, had not intended to abolish common law immunities. Thus, the Chief

cases which have cited Monroe v. Pape reveals that it has not yet been considered for its effect, if any, on the well-established rule of judicial immunity." For listings of decisions which have upheld judicial immunity, see Bauers v. Heisel, 361 F.2d 581 (3d Gir. 1966) , cert. denied, 386 U.S. 1021 (1967); Rhodes v. Meyer, 334 F.2d 709 (8th Cir.), cert. denied, 379 U.S. 915 (1964); note 157 supra.

100386 U.S. 547 (1967).

$170 I d$. at 554 .

${ }^{171}$ The clergymen's convictions under the Mississippi breach of the peace law were remanded for a new trial on appeal from the municipal police judge. At the second trial, a directed verdict was entered for the clergymen because of insufficient evidence. Id. at 550 .

${ }_{172}$ See Thomas v. Mississippi, 380 U.S. 524 (1965) (per curiam), in which the Supreme Court reversed convictions of "Freedom Riders" who had tried to use segregated bus facilities. The Pierson majority discussed the Thomas case in 386 U.S. at 550 n.4.

${ }^{173}$ The Supreme Court's treatment of the liability of the police officers in Pierson is discussed in notes 281-90 infra and accompanying text.

174386 U.S. at 554. Mr. Justice Douglas, the only dissenter, urged the Court to adopt a more limited immunity for judges, exempting "judges from liability for the consequences of their honest mistakes," $i d$. at 566, but not from liability "for the knowing and intentional deprivation of a person's civil rights." Ibid. He based his view on his belief that "every person" [in the text of \$1983] meant "every person, not every person except judges." Id. at 559 .

${ }^{176} I d$. at 554 . 
Justice noted that "Congress would have specifically so provided had it wished to abolish the doctrine."176 Therefore, common law immunity remains available to insulate judges completely from damages under section 1983.177

The broad acceptance of judicial immunity appears to be consistent with the doctrine's traditional justification, for the role which the judge plays in government demands a high degree of impartiality and independence from outside pressures if equal justice before the law is to be attained. Moreover, by raising them above the level of ordinary tort liability for their official acts, immunity helps to promote public respect for judicial officials, and therefore, for the law itself.

\section{State Prosecutors}

The decision to include the functions of state prosecutors within the inner circles of immunity ${ }^{178}$ and comity ${ }^{179}$ in section 1983 suits has been based on the similarities between judges and state prosecutors. Both judges and prosecutors unquestionably act "under color

\footnotetext{
170 Ibid.

${ }^{177}$ In some cases, judges have avoided hability under $\$ 1983$ without the aid of the doctrine of official immunity. For instance, judges sued under $\S 1983$ have been found not liable if there was no deprivation of federal rights caused by the judge. See, e.g., Harris v. Turner, 329 F.2d 918 (6th Cir.), cert. denied, 379 U.S. 907 (1964); Sires v. Cole, 314 F.2d 340 (9th Cir.), cert. denied, 374 U.S. 847 (1963); Abernathy v. Patterson, 295 F.2d 452 (5th Gir. 1961), cert. denied, 368 U.S. 986 (1962). A clear example of judicial mistake which does not violate a federal right is a "mere error of judgment." See, e.g., Sarelas v. Sbeehan, 326 F.2d 490 (7th Cir. 1963); Hurlburt v. Graham, 323 F.2d 723 (6th Cir. 1963). At least one dismissal of a $\$ 1983$ claim against a judge has been based on the running of the applicable statute of limitations. Minchella v. Estate of Skillman, 356 F.2d 52 (6th Cir.), cert. denied, 385. U.S. 861 (I966).

${ }^{178}$ The extension of judicial immunity to prosecutors acting within the scope of their duties has been described as the "practical implementation of judicial immunity." Rhodes v. Houston, 202 F. Supp. 624, 634 (D. Neb.), aff'd, 309 F.2d 959 (8th Cir. 1962), cert. denied, 372 U.S. 909 (1963).

${ }^{170}$ Since the duties of state prosecutors are as much a part of the law enforcement process as are those of judges, the doctrine of federal comity applies in the same manner to their functions when injunctions based on $\S 1983$ are sought. Therefore, no specific discussion of comity as applied to prosecutors will be attempted. For a listing of cases, see note 156 supra. The doctrine of comity, especially as it relates to state court proceedings, is discussed at notes 73-86 supra. Furthermore, although the prohibition found in 28 U.S.C. $\$ 2283$ (1964) applies only to Court proceedings which have been instituted, see note 75 supra, it has been said that federal courts, under the principle of comity, "will not enjoin a pending or future state criminal proceeding." MARSHALI, FEDERALISM AND CIVIL RIGHTS 51 (1964). Under this view, prosecutors would be insulated from injunctive actions under $\$ 1983$ in almost every instance. However, there are a few exceptions to this rule. See Dombrowski v. Pfister, 380 U.S. 479 (1965); note 86 supra.
} 
of" state authority when they execute their duties as outlined by the state. Qualifying equally as "discretionary" officers of the court, both are committed to the fair and fearless administration of the state's judicial system. These similarities, in light of the slight reference to state prosecutors in the congressional debates of 1871,180 make the enacting legislators' comments regarding the liability of judges highly relevant to any inquiry into the potential liability of state prosecutors. ${ }^{181}$

After the Tenney Court adopted the view that section 1983 did not abrogate legislative immunity, ${ }^{182}$ the Court of Appeals for the Sixth Circuit, in Kenney $v$. Fox, ${ }^{183}$ held that the inner circle of official immunity included state prosecutors. Pointing to the similarities between judges and prosecutors, the court enunciated the general rule that "a prosecuting attorney is a quasi-judicial officer and enjoys the same immunity from a civil action for damages as that which protects a judge acting within his jurisdiction ...."184 The Kenney view was followed by several other circuits. ${ }^{185}$ However, by broadening the scope of violations giving rise to section 1983 complaints, ${ }^{186}$ the Monroe decision arguably cast doubt upon the propriety of analogizing immunity for any court official from the legislative immunity of Tenney. ${ }^{187}$ Nevertheless, the initial reac-

${ }^{180}$ Senator Thurman, a Democratic opponent of the Third Enforcement Act, mentioned prosecutors in discussing the predecessor of $\$ 1983$. To show that there was no need for a federal civil remedy directed toward state court officials, Senator Thurman defended the record of state courts in North Carolina: "Now is there any complaint that these judges will not execute the law? Is there any complaint that these State attorneys will not execute the law, will not set it in motion? Nothing of that kind ...." Cong. Globe, 42d Cong., Ist Sess. app. 220 (1871) [covering 1833-1873].

181 The previously noted statements of Representatives Porter and Cook provide some inferential evidence that the sponsors of the Third Enforcement Act did not intend to abrogate immunity for judges. See notes 161.64 supra and accompanying text. Therefore, it could be persuasively argued that if the issue of prosecutors' liability had been discussed, their remarks would have been markedly similar. Additionally, when the issue of official immunity is considered, the similarities between judges and prosecutors tend to override the differences, such as the fact that the prosecutor normally makes decisions outside the glare of publicity.

${ }^{182}$ See notes 59-66 supra and accompanying text.

${ }_{183} 232$ F.2d 288 (6th Cir.), cert. denied, 352 U.S. 855 (1956).

184 Id. at 290.

${ }^{185}$ E.g., Stift v. Lynch, 267 F.2d 237 (7th Cir. 1959); Lewis v. Brautigam, 227 F.2d 124 (5th Cir. 1955).

${ }^{186}$ See notes 99-101 supra and accompanying text.

${ }^{187}$ Two reasons suggest that Monroe challenged the propriety of immunity for judicial officers of all types. First, the Court stated the purpose of $\S 1983$ in extremely broad terms, see note 99 supra and accompanying text, indicating that the need for civil relief for deprivations of civil rights would he considered paramount 
tion of lower federal courts was that immunity would continue to be available to prosecutors until there was a more explicit decision on the question by the Supreme Court or an abrogation of immunity by Congress, ${ }^{188}$ a view widely held by the courts of appeal today. ${ }^{189}$

unless strong reasons for denying recovery were presented. The Court, however, did not indicate whether official immunity would constitute such a countervailing reason. Nevertheless, by failing to mention Tenney, the Monroe Court arguably intended to leave that decision and its doctrine of legislative immunity intact. Secondly, the Monroe decision raised additional questions regarding immunity for judges and prosecutors in the context of $\$ 1983$ in explaining its grant of certiorari: "The case is here... because of a seeming conflict of that ruling [Stift v. Lynch, 267 F.2d 237 (7th Cir. 1959)] with our prior cases." 365 U.S. 167, 170 (1961). In Stift, the Court of Appeals for the Seventh Circuit had dismissed suits based on $\$ 1983$ against judges, prosecutors, and law enforcement officers. In doing so, the court expressly rejected the argument that $\$ 1983$ "makes no exceptions for judicial officers, quasi-judicial officers and law-enforcing officers." 267 F.2d at 239. However, when the Court in Monroe ruled on the question of police officers' liability, it gave no indication whether it intended the decision to negate Stift entirely, or merely to correct the Stift court in its application of $\S 1983$ to law enforcement officers.

${ }^{183}$ The view that prosecutors were still entitled to official immunity after Monroe was stated explicitly in Phillips v. Nash, 311 F.2d 513, 516 (7th Cir. 1962), cert. denied, 374 U.S. 809 (1963): "We think it will be time enough to say the federal Civil Rights Act permits any person who has been prosecuted by a State's Attorney or an Assistant State's Attorney to sue such official under the Civil Rights Act when and if Congress so determines or when and if the Supreme Court announces an extension of its holding in Monroe v. Pape."

In some cases, lower federal courts have not had to rely on the doctrine of immunity to dismiss $\$ 1983$ suits against prosecutors. For cases dismissing such suits for failure of the plaintiff to show that a federal right had been deprived, see, e.g., Egan v. City of Aurora, 365 U.S. 514 (1961); Williams v. Williams, 363 F.2d 853 (9th Gir. 1966); Smith v. Ellington, 348 F.2d 1021 (6th Cir. 1965), cert. denied, 382 U.S. 998 (1966); Harris v. Turner, 329 F.2d 918 (6th Cir.), cert. denied, 379 U.S. 907 (1964); Moss v. Hornig, 314 F.2d 89 (2d Cir. 1963). Two cases have been dismissed on procedural grounds: Minchella v. Estate of Skillman, 356 F.2d 52 (6th Cir.), cert. denied, 385 U.S. 861 (1966) (appropriate statute of limitations had run); Sires v. Cole, 314 F.2d 340 (9th Cir.), cert. denied, 374 U.S. 847 (1963) (no jurisdiction of the subject matter).

${ }^{180}$ E.g., Bauers v. Heisel, 361 F.2d 581 (3d Cir. 1966), cert. denied, 386 U.S. 1021 (1967); Gabbard v. Rose, 359 F.2d 182 (6th Cir. 1966); Byrne v. Kysar, 347 F.2d 734 (7th Gir. 1965), cert. denied, 383 U.S. 913 (1966); Rhodes v. Meyer, 334 F.2d 709 (8th Cir.), cert. denied, 379 U.S. 915 (1964); Agnew v. Moody, 330 F.2d 868 (9th Cir.), cert. denied, 379 U.S. 867 (1964); Scolnick v. Lefkowitz, 329 F.2d 716 (2d Cir.), cert. denied, 379 U.S. 825 (1964); Hurlburt v. Graham, 323 F.2d 723 (6th Cir. 1963); Sires v. Cole, 320 F.2d 877 (9th Cir. 1963); Wise v. City of Chicago, 308 F.2d 364 (7th Cir.), cert. denied, 372 U.S. 944 (1962); Kostal v. Stoner, 292 F.2d 492 (10th Cir. 1961).

Bauers v. Heisel, supra, is the most instructive modern case on prosecutor's immunity in the context of $\S 1983$. Plaintiff alleged that the defendant prosecutor had deprived him of federal rights by denying him a speedy trial and by prosecuting him while knowing he was under 18 at the time, in violation of a New Jersey statute. The Court of Appeals for the Third Circuit invoked the doctrine of immunity to dismiss the claim against the prosecutor. The court supported its decision on two grounds. First, applying the maxim that "a statute should not be considered in derogation of the common law unless it expressly so states or the result is imperatively required from the nature of the enactment," id. at 587, the court found that Congress had not in- 
While official immunity for prosecutors in section 1983 suits has been broadly recognized, lower federal courts in the past have not rigorously enforced the common law requirement that the official be acting within the scope of his duties. ${ }^{190}$ However, the recent trend has been to investigate whether a defendant prosecutor was acting as a judicial official before allowing him the defense of immunity. ${ }^{101}$ This requirement appears reasonable since the rationale for extending immunity to prosecutors involves their similarity to judges, in that both are "discretionary" officials dedicated to the impartial administration of justice. Thus, in Robichaud $v$. Ronan, ${ }^{192}$ the plain-

tended $\$ 1983$ to abolish official immunity. Secondly, the court relied on the precept that if a case may be decided on two grounds, the constitutional one is to be avoided. The Bauers court feared an interpretation of $\S 1983$ which would raise the constitutional issue of Congress's power to alter the republican form of state government. ("The United States shall guarantee to every state in this Union a republican form of government ...." U.S. CoNST. art. 4, §4.) The court reasoned that an interpretation of $\$ 1983$ abrogating immunity would destroy the independence of the state judiciary, thereby altering one aspect of a republican form of government.

In adopting the statutory interpretation that $\$ 1983$ did not abrogate immunity, the Bauers court abandoned its earlier construction of the statute and overruled Picking v. Pennsylvania R.R., 151 F.2d 240 (3d Cir. 1945), cert. denied, 332 U.S. 776 (1947), 42 N.Y.U.L. REv. 160 (1967). See notes 56-57 supra and accompanying text.

${ }^{190}$ Instead of requiring that the state official show that he was acting within the scope of his duties, the lower federal courts have often accorded immunity to state officials merely by virtue of the title they held. Thus, if the official was a state prosecutor, it was assumed that he was a "discretionary" official and that the scope of his duties for the purposes of immunity encompassed the acts done in the particular case. It made little difference whether the prosecutor had acted in a judicial capacity or in some other capacity characteristic of prosecutors. This attitude is best illustrated in Gaito v. Strauss, 249 F. Supp. 923 (W.D. Pa.), aff'd, 368 F.2d 787 (3d Cir. 1966): "Actually, we deem it unrealistic to so artificially compartmentalize the activities of a district attorney-particularly the first assistant-so as to say that his activities in interrogating a suspect are non-privileged while those activities expended in trying the case ... are privileged. All such activities should be equally privileged against damage suits." Id. at 931 .

${ }^{101}$ See, e.g., Bauers v. Heisel, 361 F.2d 581, 589-91 (3d Cir. 1966), cert. denied, 386 U.S. 1021 (1967); Robichaud v. Ronan, 351 F.2d 533 (9th Cir. 1965); Corsican Prods. v. Pitchess, 338 F.2d 441 (9th Cir. 1964); Lewis v. Brautigam, 227 F.2d 124 (5th Cir. 1955).

A similar tendency is discernible in suits against prosecutors for injunctive relief. Thus, the Supreme Court in Dombrowski v. Pfister, 380 U.S. 479 (1965), reversed the denial of an injunction against threatened prosecutions of plaintiffs under $\$ 1983$, while still recognizing the doctrine of comity as applied to judicial proceedings. The Court ruled that the prosecutions constituted harassments of the plaintiffs in the exercise of federal rights, producing "irreparable injury," and therefore comity would not bar relief. However, the decision also announced that had the defendant prosecutor executed his prosecutorial duties in good faith, the injunction would not have issued. Conceivably, harassment by means of threatened prosecutions is outside the scope of the prosecutor's duties.

192351 F.2d 533 (9th Cir. 1965). Robichaud contains an excellent summary of the traditional reasons for official immunity. 
tiff complained that the defendant county attorneys had confined her without access to a lawyer to make her confess to a murder. When the defendants claimed immunity as a defense in the section 1983 suit, the Court of Appeals for the Ninth Circuit ruled that they had lost their immunity by acting more as police investigators than as judicial officers. ${ }^{193}$ Thus, the court held that immunity would not extend to prosecutors unless the acts in question were done "in the performance of an integral part of the judicial process." 194

The traditional justification for official immunity in the context of section 1983 seems valid in the case of state prosecutors. ${ }^{195}$ Since prosecutors are responsible for distinguishing criminal cases meriting prosecution and those frivolous in nature, ${ }^{196}$ their independence of judgment in making this decision warrants protection. In addition, fear of federal court interference with the state prosecutor's decision to enforce certain state laws could produce a potential hesitancy in him to enforce other state laws. Moreover, such potential yielding to intimidation might ultimately cause the public to view the prosecutor's decisions as unworthy of respect.

$103 I d$. at 536.

${ }^{104}$ Ibid. Two other courts of appeals expressly agree with Robichaud that the common law immunity requirement that the officer be acting within the scope of his duties should be rigorously enforced. In Corsican Prods. v. Pitchess, 338 F.2d 441 (9th Cir, 1964), the Court of Appeals for the Ninth Circuit, which also decided the Robichaud case, stated: " $[P]$ rosecutors are not immune from suit under the Act simply as a matter of status wholly without regard to the nature of their conduct." Id. at 444. In Bauers v. Heisel, 361 F.2d 581 (3d Cir. 1966), cert. denied, 386 U.S. 1021 (1967), the Court of Appeals for the Third Circuit pointed out that in order to determine "the question of whether a prosecuting attorney is liable for acts done in his official capacity, we must decide whether his duties are sufficiently judicial as to cloak him with the same immunity afforded judges or are so closely related to those duties of law enforcement officials as to amerce him with potential civil liability for his imprudent actions." Id. at 589. Finally, in the relatively early case of Lewis v. Brautigam, 227 F.2d 124 (5th Cir. 1955), the Court of Appeals for the Fifth Circuit held a prosecutor liable on the theory that "if the State's Attorney ordered and directed the officers to force the plaintiff to plead guilty, then certainly he is no less liable than are those who carried out his instructions. It would be wrong to hold the officers liable but the State's Attorney exempt." Id. at 129.

${ }^{105}$ In Bauers v. Heisel, supra note 194, the court affirmatively recognized the importance of two reasons underlying nonliability for prosecutors: to protect the independeut judgment of officials given discretion in the public interest, id. at 588-89, and to maintain the federal-state balance, id. at 589 .

${ }^{108}$ Cf. Moss v. Hornig, 314 F.2d 89 (2d Cir. 1963). The importance of the prosecutor's decisions in determining which cases to prosecute is strongly emphasized in THE President's COMm'n on Law ENForcement and Admisistration of Justice, The ChalLENGE OF CRIME IN A FREE SOCIETY 133-34 (1967). 


\section{Minor Court Officers}

Minor state court officers, such as clerks of court, bailiffs, and agents of the court, ${ }^{197}$ are considered "under color of" state law when they execute their duties. Therefore, their liability under section 1983 turns upon whether they are entitled to the benefits of official immunity or federal comity. This determination unfortunately cannot be made from the dearth of the enacting legislators' comments regarding potential liability for such minor state court officials. ${ }^{198}$ Assuming, however, that the Third Enforcement Act was not intended to extinguish the doctrine of official immunity, an inquiry into the common law requirements of immunity becomes relevant. Specifically, "ministerial" officials, as opposed to those who perform "discretionary" functions were not granted the common law protection of immunity. ${ }^{199}$ Consequently, lower federal courts have adopted the states' view that clerks, bailiffs, and other agents of the court cannot successfully invoke the immunity doctrine when they have allegedly violated federal rights by exercising the ordinary powers of their positions. ${ }^{200}$ Although the exercise of these lawful

107 Persons acting as agents of the court who have heen sued under $\$ 1983$ include medical witnesses, and/or medical commissions appointed by the court to submit their findings, Duzynski v. Nosal, 324 F.2d 924 (7th Cir. 1963), and state deposition officers, Sarelas v. Sheehan, 353 F.2d 5 (7th Cir. 1965). This category of persons who act "under color of" state law in carrying out a duty given them by the court or in testifying during a judicial proceeding could include any expert witness named by the court, as well as arbitrators and special masters appointed by the court. These suggestions are, however, by no means exhaustive.

${ }^{108} \mathrm{As}$ is true for many categories of state officials, the legislative history of $\$ 1983$ sheds little light on the question of liability of minor court officers. Representative Arthur, opposing the Third Enforcement Act, pointed out that the predecessor of $\$ 1983$ was so broad that it would cause every court officer, "great or small," to "enter upon and pursue the call of official duty with the sword of Damocles suspended over him by a silken thread ... ." Cong. GLOBE, 42d Cong., 1st Sess. 366 (1871) [covering 1833-1873]. See also note 205 infra.

${ }^{100}$ See notes 51-52 supra and accompanying text. See generally Davis, Administrative Officers' Tort Liability, 55 Mrch. L. REv. 201 (1956); Gray, Private Wrongs of Public Servants, 47 CALIF. L. Rev. 303 (1959); Handler and Klein, The Defense of Privilege in Defamation Suits Against Government Executive Officials, 74 HARv. L. REv. 44 (1960); Jaffe, Suits Against Governments and Officers: Damage Actions, 77 HARv. L. REv. 209 (1963).

${ }^{200}$ See Johnson v. Crumlish, 224 F. Supp. 22 (E.D. Pa. 1963), in which a district court held liable a clerk of court and numerous other officials for imprisoning plaintiff for eight days without allowing him to see a judge.

An example of the usual statutory powers of a clerk of court is provided by N.C. GEN. StAT. §2-16 (1953); "1. To issue subpoenas to compel the attendance of any witness residing or being in the State, or to compel the production of any bond or paper, material to any inquiry pending in his court . . . 4. To issue citations and orders to show cause to parties in all matters cognizable in his court, and to compel 
powers may necessitate choosing between valid alternatives, minor court officials do not possess the traditional attributes of "discretionary" officers. ${ }^{201}$ Therefore, the importance of independence in decision-making by minor court officials is not so substantial as to negate the interest in providing for civil redress. ${ }^{202}$ Furthermore, it would appear that federal comity should not bar section 1983 injunctive relief against the exercise of ordinary duties by minor court officials, since these functions are hardly analogous to those typically protected by comity. ${ }^{203}$ Moreover, it makes no difference that the minor court officials exercise of ordinary powers which violates a federal right was done pursuant to or in violation of his duties. ${ }^{204}$ In either case, liability is imposed.

Although the doctrines of comity and immunity are usually unavailable to minor state court officials, both defenses may be recognized where the officer allegedly violates federal rights while acting strictly pursuant to a judicial order. ${ }^{205}$ In this situation, the officer

the appearance of such parties .... 7. To preserve order in his court and to punish contempts .... 9. To open, vacate, modify, set aside, or enter as of a former time, decrees or orders of his court, in the same manner of courts of general jurisdictiou."

${ }^{201}$ For a listing of the factors which are often present when courts classify an officer as "discretionary," see note $\mathbf{5 2}$ supra.

${ }^{202}$ See notes 51-52 supra and accompanying text.

${ }^{208}$ State functions typically protected by federal comity are those which are considered incidents of state sovereignty, such as state court and legislative proceedings. Few functions performed by minor state court officials rise to the level of these aspects of state sovereignty.

$20 \leq$ See Lane v. Wilson, 307 U.S. 268 (1939); Nixon v. Herndon, 273 U.S. 536 (1927); Meyers v. Anderson, 238 U.S. 368 (1915), for cases holding liable various elections officers for violating federal rights while acting according to the state law. However, Pierson v. Ray, 386 U.S. 547 (1967), seems to have modified this harsh result by holding that minor officials who enforce a state law only subsequently held unconstitutional will not be liable if they act in good faith and with probable cause. See notes 281-90 infra. Furthermore, it seems that a good faith standard should be applied if the clerk's function has a judicial character, such as the power of a North Carolina clerk "to preserve order and to punish contempts" (N.C. GEN. STAT. \$2.16 (1953)). Thus, for example, a valid judicial interest in preserving court order would tend to outweigh the interest in providing redress in many circumstances. However, where the powers, even if discretionary in some sense, become more perfunctory and "ministerial," the stricter standard of probable cause should be employed. No state interest in protecting minor clerk discretion in these situations exists to balance against the need for personal relief.

${ }^{205}$ During the congressional debates of $187 \mathrm{I}$, Representative Lewis, an opponent of the predecessor of $\S 1983$, commented on the possible liability of ministerial officers while acting upon a judicial order: "[A] ministerial officer is subject to the same pains and penalties [as judges], though simply executing the process of a State court, about which he has no discretion, and the legality of which he has no right to question." Cong. Globe, 42d Cong., Ist Sess. 385 (1871) [covering 1833-1873]; see id. at 366 (remarks of Representative Arthur). The rephes of Republican Represeutatives Cook and 
may successfully assert official immunity or comity as a defense if he was acting "at the express direction of the judge whose arm and agent he then was." 200 This exception is based on the fact that the particular officer has no reasonable alternative but to comply with the judge's order. ${ }^{207} \mathrm{He}$ is not the responsible cause of the deprivation of a federal right. Furthermore, disobedience and disloyalty to his superior, the judge, is discouraged by allowing the minor court officer the defense of immunity or comity in this situation. Moreover, assertion of either defense by the officer precludes a collateral attack on the originators of the decision, the judges, who are charged with making decisions normally protected by either immunity or comity.

\section{High Executive Officials}

State governors and high executive officials at the state "cabinet" level clearly are acting "under color of" state authority when they perform their duties on behalf of the state. Once within this outer circle of potential defendants, ultimate liability for high executive officials will be determined by whether or not these officers are en-

Porter to the effect that state court officials might not be liable under the predecessor of $\S 1983$ give a partial, although inconclusive, answer to the allegations of the Demo. crats. See notes 161-64 supra and accompanying text.

${ }^{206}$ Haldane v. Chagnon, 345 F.2d 601, 604 (9th Cir. 1965). The rule that official immunity may be available to minor court officials who are executing judicial orders when their act allegedly deprives another of a federal right has been upheld in the following cases: Clerks: e.g., Rhodes v. Meyer, 334 F.2d 709 (8th Cir.), cert. denied, 379 U.S. 915 (1964); Agnew v. Moody, 330 F.2d 868 (9th Cir.), cert. denied, 379 U.S. 867 (1964); Sires v. Cole, 314 F.2d 340 (9th Cir.), cert. dcnied, 374 U.S. 847 (1963); Carpenter v. Dethmers, 253 F.2d 131 (6th Cir. 1958). Bailiffs: e.g., Haldane v. Chagnon, supra; Agnew v. Moody, supra. State Deposition Officers: e.g., Sarelas v. Sheehan, 353 F.2d 5 (7th Cir. 1965); Sarelas v. Sheehan, 326 F.2d 490 (7th Cir. 1963), cert. denied, 377 U.S. 932 (1964). Medical Experts: e.g., Duzynski v. Nosal, 324 F.2d 924 (7th Cir. 1963).

Few cases, if any, have considered the issue of injunctive relief against minor court officials who are enforcing judicial orders. However, it seems reasonable that if an injunction were sought against the execution of a court order by a minor court official, federal comity would bar its issuance. Court orders must of necessity be considered state court proceedings, which comity protects in most cases. See notes 73.86 supra and accompanying text. In addition, the reasons which motivate the extension of immunity to minor court officials who are enforcing court orders also support the application of the comity doctrine to the same situation. See text following note 207 infra.

${ }^{207}$ See Haldane v. Chagnon, supra note 206; Rhodes v. Houston, 202 F. Supp. 624 (D. Neb.), aff'd, 309 F.2d 959 (8th Cir. 1962), cert. denied, 372 U.S. 909 (1963). The minor court official does have the alternative of refusing to comply with the judge's orders, but the sanction for noncompliance is a citation and conviction for contempt of court. 
compassed within the inner circles of official immunity and federal comity. ${ }^{208}$ As "discretionary" state officials, state governors were clearly entitled to immunity from ordinary tort liability while acting within the scope of their official duties. ${ }^{209}$ However, no reasonable consensus can be ascertained from the congressional debates over section 1983 as to whether executive immunity was intended to be abrogated by the statute. ${ }^{210}$ Since the text of section 1983 does not expressly demand abrogation, it would seem that official immunity for state executives would be consistent with the maxim that a statute "should not be considered in derogation of common law unless it expressly so states or that result is imperatively required from the nature of the enactment."'211

Just as lower federal courts derived judicial immunity from the legislative immunity recognized in Tenney, the courts have also accorded official immunity to high state executives-the third branch

${ }^{203}$ Although no recent decisions have considered the issue, the doctrine of federal comity ought to be available to prevent frequent federal court injunctions based on $\$ 1983$ from being issued against state governors. The functions performed by state governors seem as much incidents of state sovereignty as are state court proceedings. Thus the embarrassing federal-state conflict-which comity seeks to prevent-is highly likely if federal courts frequently enjoin the actions of high executive officials. See generally notes 72,153 supra.

In order to obtain equitable relief against state governors, a plaintiff must meet the Douglas-Stefanelli test of irreparable injury. See notes 73-86 supra and accompanying text. As a prime illustration of how irreparable injury might be shown against high governmental officials, see Dombrowski v. Pfister, 380 U.S. 479 (1965); note 86 supra.

${ }^{200}$ See, e.g., Barr v. Matteo, 360 U.S. 564 (1959); Spalding v. Vilas, 161 U.S. 483 (1896); Norton v. McShane, 332 F.2d 855 (5th Cir. 1964), cert. denied, 380 U.S. 981 (1965). See generally Gray, Private Wrongs of Public Servants, 47 CaLIF. L. Rev. 303 (1959); Handler and Klein, The Defense of Privilege in Defamation Suits Against Government Executive Officials, 74 HARv. L. Rev. 44 (1960); Prosser, TORTS 1126 (3d ed. 1964).

${ }^{210}$ Democratic Representative Arthur was the only Congressman during the debates to speak directly to the question of the liability of state governors: "[]]f ... the Governor enforces [the law] . . . for a mere error of judgment, [he is] . .. liable." Conc. GLOBE, 42d Cong. Ist, Sess. 366 (1871) [covering 1833-1873]. Even though there were no other direct comments on the issue of the liability of other state executives, Democrats and Republicans did engage in a lively debate concerning the reason for the failures of Tennessee's Republican governor. Republicans blamed Democratic state legislators, who "had stripped [the governor] . . o of all executive power by repealing laws that had been passed with the view of giving the Executive power to protect the citizens of the State." Id. at app. 309 (remarks of Representative Maynard). The Democrats offered a different explanation: the laws were not faithfully executed "because [the governor] . . . knew, and his party knew, that if these supposed rebel Ku Klux were caught the majority of them would be found to belong to his own party ...." Id. at app. 203 (remarks of Representative Garrett).

${ }_{211}$ Bauers v. Heisel, 361 F.2d 581, 587 (3d Cir. 1966), cert. denied, 386 U.S. 1021 (1967). 
of state policy-makers. ${ }^{212}$ However, seldom have courts dismissed section 1983 damages claims on the basis of official immunity. 213 Nor has comity often been used to dispose of section 1983 injunctive claims against state executives. ${ }^{214}$ Instead, in the few cases brought against these officials, dismissals have been granted on alternative grounds: failure to demonstrate that a federal right had been deprived; 215 inadequate showing that the particular executive caused

${ }^{212}$ The Supreme Court has continually recognized the defense of official immunity from ordinary tort liability for high executive officials of government since its decision in Spalding v. Vilas, 161 U.S. 483 (1896). As recently as 1959, the Court affirmed and extended the scope of immunity to executive officials below the "cabinet" level, stating that executive immunity "is . . . an expression of a policy designed to aid in the effective functioning of government." Barr v. Matteo, 360 U.S. 564, 572-73 (1959). Without question, the above reasoning should apply to the use of executive immunity in the context of $\S 1983$.

The Barr Court expressly approved the oft-quoted rationale for exccutive immunity given by Judge Learned Fand in Gregorie v. Biddle, 177 F.2d 579, 581 (2d Cir. 1949), cert. denied, 339 U.S. 949 (1950): "It does indeed go without saying that an official, who is in fact guilty of using his powers to vent his spleen upon others, or for any other personal motive not connected with the public good, should not escape liability for the injuries he may so cause; and, if it were possible in practice to confine such complaints to the guilty, it would be monstrous to deny recovery. The justification for doing so is that it is impossible to know whether the claim is well founded until the case has been tricd, and that to submit all officials, the innocent as well as the gnilty, to the burden of a trial to the inevitable danger of its outcome, would dampen the ardor of all but the most resolute, or the most irresponsbile, in the unflinching discharge of their dutics." The Hand rationale of executive immunity has a special bearing on immunity under $\$ 1983$, for in Gregorie, one of the claims against various United States officials-including two Attorney Generals-was based on $\$ 1983$. Although Judge Hand found $\$ 1983$ did not apply because the acts were not done "under color of" state law, it is reasonable to assume that he was aware of the problem of immunity under the statute and that his remarks were partially in response to that issue.

${ }^{213}$ Only one case since Monroe denies the liability of a high executive official on the basis of immunity alone. See Scolnick v. Lefkowitz, 329 F.2d 716 (2d Cir. 1964). The early case of Picking v. Pennsylvania R.R., 151 F.2d 240 (3d Cir. 1945), cert. denied, 332 U.S. 776 (1947), held the governor of Pennsylvania liable in damages, but that decision was first discredited by the result in Tenney and subsequently overruled by the Court of Appeals for the Third Circuit itself in Bauers v. Heisel, 361 F.2d 581 (3d Cir. 1966), cert. denied, 386 U.S. 1021 (1967); see note 182 supra.

214 The Supreme Court acknowledged the availability of federal comity as a defense to $\S 1983$ injunctive claims against high executive officials in Dombrowski v. Pfister, 380 U.S. 479 (1965). However, in that case, "irreparable injury" was also found, thereby making the doctrine of comity inapplicable. See also Abernathy v. Patterson, 295 F.2d 452 (5th Cir. 1961).

${ }_{215}$ E.g., Ream v. Handlcy, 359 F.2d 728 (7th Cir. 1966); Smith v. Ellington, 348 F.2d 1021 (6th Cir. 1965), cert. denied, 382 U.S. 998 (1966); Poole v. Barnette, 336 F.2d 267 (5th Cir. 1964); Powell v. Work Compensation Bd., 327 F.2d 131 (2d Cir. 1964); Association for the Preservation of Freedom of Choice, Inc. v. Simon, 299 F.2d 212 (2d. Cir. 1962). 
the infringement; 216 the reasonableness of the executive's policy decision, notwithstanding the alleged infringement of a right; ${ }^{217}$ and the invocation of the federal abstention doctrine. ${ }^{218}$ It should be noted, however, that the utilization of these alternative grounds for dismissal appears to indicate a reluctance on the part of the courts to entertain section 1983 claims against high executive officials in the first instance, rather than any unwillingness to extend official immunity to such officers. ${ }^{219}$

The reasons underlying both immunity and comity are especially convincing in the case of high executive officials. Specifically, independence of decision-making for state executives, who are responsible for the daily operation of state government, is essential if the "effective functioning of government" is to be secure.220 Further, federal-state friction at the highest executive level of state government may be avoided by the application of comity, resulting in a smoother working balance between the federal government and the states. ${ }^{221}$

\section{Prison Wardens, Mental Hospital Superintendents, and Their Super- visory Boards}

After Monroe enhanced the utility of section 1983 as a remedy for redressing denials of federal rights, ${ }^{222}$ there was a marked increase in suits against state prison wardens, mental hospital superintendents, and the supervisory boards of such state institutions. ${ }^{223}$ Unquestion-

\footnotetext{
${ }^{210}$ E.g., Joyce v. Ferrazzi, 323 F.2d 931 (1st Cir. 1963); Nesmith v. Alford, 318 F.2d 110 (5th Cir. 1963), cert. denied, 375 U.S. 975 (1964).

${ }^{217}$ E.g., Labat v. McKeithen, 361 F.2d 757 (5th Cir. 1966). When the decision by the high executive is found to be a reasonable one, lower federal courts generally hold that there was no actual violation of a federal right. Therefore, a cause of action under $\S 1983$ is not stated.

${ }^{218}$ See Abernathy v. Pattersou, 295 F.2d 452 (5th Cir. 1961), cert. denied, 368 U.S. 986 (1962). Federal abstention is an aspect of the doctrine of federal comity. Thus, federal courts may, in their discretion, abstain from considering certain cases if there is a possibility that a narrowing construction of a state law by state courts would make it possible for the federal courts to avoid a constitutional question. See Railroad Comm'n v. Pullman Co., 312 U.S. 496 (1941). For recent limitations on the doctrine of abstention, see Dombrowski v. Pfister, 380 U.S. 479 (1965); Comment, 1965 DUke L.J. 102; note 86 supra.

${ }^{210}$ The Supreme Court's decision in Pierson v. Ray, 386 U.S. 547 (1967), seems to support the conclusion that official immunity would be available to all officials who were entitled to it at common law.

220 Barr v. Matteo, 360 U.S. 564, 572-73 (1959).

221 See note 208 supra and accompanying text.

222 See notes 99-101 supra and accompanyiug text.

${ }^{223}$ Since the Monroe decision in 1961, at least thirty-three cases brought against either prison wardeus, mental hospital superintendents, or persons associated with
} 
ably, state institution administrators act "under color of" state law when executing their state-imposed duties. Therefore, relief under section 1983 has turned chiefly upon whether or not these state officials could successfully rely on either the doctrine of immunity or upon the rule of federal comity.

Unfortunately, the congressional debates over the progenitor of section 1983 are barren of references to prison wardens, hospital superintendents, or their governing boards. Furthermore, no state official discussed by the Congress of 1871 has duties sufficiently similar to those of state administrators to permit a meaningful analogy, such as the one drawn between judges and prosecutors.224 Regardless, after the Supreme Court in Tenney held that section 1983 did not eliminate the doctrine of official immunity, ${ }^{225}$ lower federal courts extended the inner circle of protection to include state institution administrators, if they were acting as state jailors or custodians. ${ }^{220}$ In the first case so to extend immunity, Francis $v$. Lyman, ${ }^{227}$ the defendant, the superintendent of a state farm for mental defectives, had allegedly kept the plaintiff confined illegally, thereby depriving him of liberty without due process. ${ }^{228}$ In holding the superintendent not liable in damages under section 1983, the Court of Appeals for the First Circuit announced that official immunity was available as a defense if the detention, even though it infringed federal rights,

these state institutions have reached the Courts of Appeals. See cases cited notes 230, 240-46 infra.

224 See note 177 supra and accompanying text.

${ }^{225}$ See notes 59-66 supra and accompanying text.

${ }^{226}$ Few suits, if any, have been brought under $\$ 1983$ seeking an injunction against the institution administrator from detaining a plaintiff. However, it seems reasonable that if a plaintiff sought to enjoin a prison administrator from enforcing a court order of detention, comity would prevent issuance of the injunction. The detention order could easily be viewed as an aspect of "state court proceedings," protected from injunction by 28 U.S.C. $\$ 2283$ (1964). See notes 73-79 supra and accompanying text. See also note 231 infra.

22т 216 F.2d 583 (1st Cir. 1954).

${ }^{228}$ In Lyman, suit was brought under $\$ 1983$ against a state judge, members of the state commission of correction, and state parole board members, in addition to the superintendent of the state farm. The plaintiff alleged that his federal rights were violated because the judicial commitment order was made without giving him sufficient notice of a hearing or an opportunity to be heard. However, the court dismissed the complaint against the judge on the basis of judicial immunity. Francis v. Crafts, 203 F.2d 809 (1st Cir.), cert. denied, 346 U.S. 835 (1953). Dismissal of the compaint of illegal detention against the commissioners of correction and members of the parole board was based on the theory that they had no authority to inquire into the judicial order, and therefore had not caused any deprivation of federal rights. 216 F.2d at 584-86. 
was effected pursuant to a court order. ${ }^{229}$ Since the superintendent had no power to challenge the commitment order, he could not reasonably be held liable for obeying it. ${ }^{230}$ In detaining the plaintiff, the superintendent had merely acted as state custodian, and as such his protection from liability for confining a person was derived from judicial immunity itself. ${ }^{231}$ Subsequent cases have consistently followed the Lyman rule that state institution administrators are free from section 1983 liability when they detain persons under court order. ${ }^{232}$

In addition to detention under court order, another common circumstance which gives rise to section 1983 claims against state institution administrators is their treatment of prisoners and patients. ${ }^{233}$ The earlier view was that state prison wardens and hospital superintendents were insulated from all section 1983 actions concerning treatment because the federal courts refused to oversee state prisons. ${ }^{234}$ In recent years, however, federal courts have evolved a rule of reasonable discretion, ${ }^{235}$ similar to the rule used to determine the liability

220 Id. at 588 .

${ }^{280}$ Accord, e.g., Hoffman v. Halden, 268 F.2d 280 (9th Cix. 1959), overruled on other grounds, Cohen v. Norris, 300 F.2d 24 (9th Cir. 1962); Kenney v. Fox, 232 F.2d 288 (6th Gir. 1956), cert. denied, 352 U.S. 855 (1956); Dunn v. Gazzola, 216 F.2d 709 (Ist Cir. 1954); Rhodes v. Houston, 202 F. Supp. 624 (D. Neb.), aff'd, 309 F.2d 959 (8th Cir. 1962), cert. denied, 372 U.S. 909 (1963).

$331216 \mathrm{~F} .2 \mathrm{~d}$ at $588-89$. If a federal court were to order a state institution administrator to release the plaintiff, this action would amount to a collateral attack on a state court judgment. Such an attack based on $\$ 1983$ was expressly disapproved by the Supreme Court in Stefanelli v. Minard, 342 U.S. 117 (1951), notes 85-86 supra and accompanying text, on the basis of the doctrine of federal comity.

${ }^{282}$ E.g., Joyce v. Ferrazzi, 323 F.2d 931 (lst Cir. 1963); Nesmith v. Alford, 318 F.2d 110 (5th Cir. 1963), cert. denied, 375 U.S. 975 (1964); Hoffman v. Halden, 268 F.2d 280 (9th Cir. 1959), overruled on other grounds, Cohen v. Norris, 300 F.2d 24 (9th Cir. 1962); Dunn v. Gazzola, 216 F.2d 709 (1st Cir. 1954); Rhodes v. Houston, 202 F. Supp. 624 (D. Neb.), affd, 309 F.2d 959 (8th Cir. 1962), cert. denied, 372 U.S. 909 (1963). The reason for immunizing state institution administrators from liability when acting as state custodians is similar to the rationale for the immunity of minor court officials who execute court orders. See notes 205-07 supra and accompanying text.

${ }^{288}$ The care and treatment of prisoners and mental patients was deemed a "ministerial" act by the common law. Therefore, immunity was not available as a protection from suits for damages. See Prosser, TorTs $\$ 126$ (3d ed. 1964).

${ }^{236}$ Thus, the rule of federal comity was utilized to prevent either the recovery of damages or injunctions against state institution administrators. For judicial treatment of this aspect of federal comity, see, e.g., Cole v. Smith, 344 F.2d 72l (8th Cir. 1965); United States v. Ragan, 337 F.2d 425 (7th Cir. 1964), cert. denied, 380 U.S. 985 (1965); Weller v. Dickson, 314 F.2d 598 (9th Cir.), cert. denied, 375 U.S. 845 (1963); Rhodes v. Houston, 202 F. Supp. 624 (D. Neb.), affd, 309 F.2d 959 (8th Cir. 1962), cert. denied, 372 U.S. 909 (1963).

285 See, e.g., Rivers v. Royster, 360 F.2d 592 (4th Cir. 1966); Jobson v. Henne, 355 F.2d 129 (2d Cir. 1966); Williford v. California, 352 F.2d 474 (9th Cir. 1965); Richey v. 
of local boards and councils. ${ }^{230}$ Thus, if the particular treatment promotes a valid administrative interest-usually prison disciplinewhich outweighs the competing interest in redressing infringements of colorable rights, discretion is said to have been reasonably exercised and no liability will be found. To resolve the issue of "reasonableness," federal courts evaluate the circumstances surrounding the particular administrative decision. Thus, in Jobson $v$. Henne, ${ }^{237}$ the Court of Appeals for the Second Circuit applied a rule of reasonable discretion to a state mental hospital director when the complaint involved treatment accorded the plaintiff patient. ${ }^{238}$ In holding the director liable in damages, the court determined that the need to have a patient earn income to finance his own treatment was not a reasonable justification for imposing unusually long working hours on the patient, in violation of due process. ${ }^{239}$

The rule of reasonable discretion has been most frequently applied when prison or hospital treatment infringes "fundamental" rights. Thus, where the "preferred freedoms" of the first amendment are involved, the necessity for a particular regulation to the proper functioning of the hospital or prison must be considerable in order

Wilkins, 335 F.2d 1 (2d Cir. 1964); Pierce v. La Vallee, 293 F.2d 233 (2d Cir. 1961); Sewell v. Pegelow, 291 F.2d 196 (4th Gir. 1961). Federal courts of appeals have not generally denominated the test utilized to determine the liability of prison-hospital administrators as a "rule of reasonable discretion." However, it seems appropriate so to name the test, for it seeks to protect administrators if they have reasonably exercised their state-authorized discretion.

The rule of reasonable discretion as applied to state institution administrators is derived basically from the rule of federal comity. Just as the Douglas-Stefanelli requirement for injunctive relief was relaxed in the case of local boards and councils, see notes 142-43 supra and accompanying text, so it has been relaxed with respect to institution administrators. Although the courts give no reason for such a change, it seems that the greater probability of violations of federal rights at the hands of prison-hospital administrators, coupled with the unlikely prospects of judicial review of their policies and programs by the state courts, has necessitated greater federal court inquiry into prison-hospital treatment of inmates. Compare Dombrowski v. Pfister, 380 U.S. 479 (1965), note 90 supra. The rule of reasonable discretion is better adapted to such inquiry than is either the doctrine of immunity or the principle of federal comity. Furthermore, treatment of patients and prisoners does not seem to be the kind of function normally considered as an incident of state sovereignty. Therefore federal-state friction is less probable.

${ }^{230}$ See notes $142-43$ supra and accompanying text.

237355 F.2d 129 (2d Cir. 1966).

${ }^{238}$ The court in Jobson acknowledged that state mental hospital directors may use the defense of official immunity in some instances, but stated that the doctrine "should be sparingly applied in suits brought under $\$ 1983$ " alleging unconstitutional treatment of patients or prisoners. Id. at 133-34.

${ }^{239}$ Id. at 131-32. 
to establish the reasonableness of the regulation. ${ }^{240}$ For example, a prison rule or punishment which infringes freedom of religion will generally be held "unreasonable,"241 unless compelling evidence is presented that such restrictions are essential to maintain discipline. ${ }^{242}$ Likewise, rules which restrict prisoners' communication by mail with the courts and lawyers are often found to be "unreasonable" because they act as unnecessary restrictions on the prisoners' rights to judicial review. ${ }^{243}$ Conversely, regulations of prisoner mail with other per-

${ }^{210}$ Cases in which the administrative interest of the state institution has been found to outweigh the importance of providing redress under the particular circumstances include Labat v. McKeithen, 361 F.2d 632 (5th Cir. 1966); Walker v. Pate, 356 F.2d 502 (7th Cir.), cert. denied, 384 U.S. 966 (1966); United States ex rel. Lee v. Illinois, 343 F.2d 120 (7th Cir. 1965); Gaito v. Prasse, 312 F.2d 169 (3d Cir.), cert. denied, 374 U.S. 816 (1963); Hatfield v. Bailleaux, $290 \mathrm{~F} .2 \mathrm{~d} 632$ (9th Cir.), cert. denied, 368 U.S. 862 (1961). Other cases have declared that the importance of protecting the federal right infringed outweighed the administrative interest to be served by the rule or policy which violated the right. E.g., Rivers v. Royster, 360 F.2d 592 (4th Cir. 1966); Williford v. California, 352 F.2d 747 (9th Cir. I965); Sewell v. Pegelow, 291 F.2d 196 (4th Cir. 1961). See generally Note, Constitutional Rights of Prisoners: The Developing Law, 110 U. PA. L. REv. 985 (1962).

${ }^{211}$ E.g., Cooper v. Pate, 378 U.S. 546 (1964) (per curiam); Williford v. California, supra note 240; Richey v. Wilkins, 335 F.2d I (2d Cir. 1964); Pierce v. La Vallee, 293 F.2d 233 (2d Cir. 1961); Sewell v. Pegelow, supra note 240. But cf. Sostre v. McGinnis, 334 F.2d 906 (2d Cir.), cert. denied, 379 U.S. 892 (1964).

${ }_{242}$ In Pierce v. LaVallee, 319 F.2d 844 (2d Cir. 1963) (per curiam), cert. denied, 376 U.S. 918 (1964), the Court of Appeals for the Second Circuit refused to issue an injunction against defendant prison officials who had allegedly punished plaintiffs for studying the Black Muslim religion. The Court said there was no showing that the punishment was the result of their religious beliefs; rather, the defendants had attempted to prevent the "agitation" caused by the plaintiffs.

${ }_{248}$ In DeWitt v. Pail, 366 F.2d 682 (9th Cir. 1966), defendant prison officials were found liable for confiscating plaintiff prisoner's legal papers, even though they claimed prison discipline as their justification. The court reasoned as follows: "When the efforts of a state prisoner to obtain available state appellate review of his conviction are frustrated by the action of penal officials, there has been a violation of the Due Process Clause of the Fourteenth Amendment. Reasonable access to the courts, state and federal, is guaranteed by that clause." Id. at 685. See also Swartt v. Avery, 370 F.2d 788 (6th Cir. 1967). Federal courts of appeals in Lee v. Tahash, 352 F.2d 970 (8th Cir. 1965) and Ortega v. Ragen, $216 \mathrm{~F} .2 d 561$ (7th Gir. 1954), cert. denied, 349 U.S. 940 (1955), dealt with the issue of prisoner correspondence with the courts, indicating that such communication could not be unduly restricted. However, the facts in neither case justified a finding that the prison officials had acted "unreasonably" in promulgating the particular regulation. Cf. Weller v. Dickson, 314 F.2d 598 (9th Cir.), cert. denied, 375 U.S. 845 (1963); United States ex rel. Hoge v. Bolsinger, 311 F.2d 215 (3d Cir. 1962) (per curiam), cert. denied, 372 U.S. 931 (1963).

A related problem involves balancing a prisoner's access to various legal materials needed to pursue his appeal against the interest in maintaining prison discipline. See, e.g., Walker v. Pate, 356 F.2d 502 (7th Cir.), cert. denied, 384 U.S. 966 (1966) (damages and injunction denied); Williams v. Wilkins, $315 \mathrm{~F} .2 \mathrm{~d} 396$ (2d Cir.), cert. denied, 375 U.S. 852 (1963) (injunction denied); Gaito v. Prasse, 312 F.2d 169 (3d Cir.), cert. denied, 374 U.S. 816 (1963) (injunction denied); Hatfield v. Bailleaux, 290 F.2d 632 (9th Gir.), cert. denied, 368 U.S. 862 (1961) (injunction denied). 
sons are often sustained because of the administrative interest in preventing fires which might result from accumulated paper in cells. ${ }^{244}$ Denial of medical treatment may be classified as "unreasonable," depending on the circumstances. ${ }^{245}$ Finally, liability is frequently based on an arbitrary denial of equal treatment to prisoners. ${ }^{240}$

The basis for sanctioning the use of the doctrine of immunity in the case of detention of persons by state institution administrators seems highly desirable when placed in juxtaposition to the reasons for protecting other state officials from damages under section 1983. Allowing prison-hospital administrators and their advisory boards to assert immunity in this situation is supported by two policies: ( 1 ) the person who is not the responsible cause of the violation of federal rights should not be liable; and (2) obedience to judicial orders should be promoted. Likewise, employment of the rule of reasonable discretion-instead of the doctrine of comity-when the claim rests on prisoner-patient treatment appears sound. Although federal interference in this situation does tend to affect the federal-state relationship, the danger of federal-state friction-which comity seeks to prevent-is not substantial, since prison and hospital administrators do not make decisions affecting the entire state. ${ }^{247}$ Moreover, adoption of a rule of reasonable discretion permits the retention of a large measure of state autonomy in prison-hospital policy-making. These factors, coupled with the high probability that violations of

\footnotetext{
244 Labat v. McKeithen, 361 F.2d 757 (5th Cir. 1966); cf. United States ex rel. Lce v. Illinois, 343 F.2d 120 (7th Cir. 1965).

${ }^{215}$ E.g., Stiltner v. Rhay, 371 F.2d 420 (9th Cir. 1967); Jobson v. Henne, 355 F.2d 129 (2d Cir. 1966); Hirons v. Director, Patuxent Institute, 351 F.2d 613 (4th Cir. 1965). But see Snow v. Gladden, 338 F.2d 999 (9th Cir. 1964). However, in Pennsylvania ex rel. Gatewood v. Hendrick, 368 F.2d 179, 180 (3d Gir. 1966) (per curiam), the court stated that improper medical treatment "was not a denial of rights secured by the federal Constitution or laws."

${ }^{248}$ E.g., Rinaldi v. Yeager, 384 U.S. 305 (1966); Rivers v. Royster, 360 F.2d 592 (4th Cir. 1966); see Snow v. Gladden, supra note 245. However, in Walker v. Pate, 356 F.2d 502 (7th Cir.), cert. denied, 384 U.S. 966 (1966), the court dismissed a $\$ 1983$ claim alleging that defendant prison official had denied plaintiff the privilege of visiting with his wife, while such privilege was accorded other prisoners. The court ruled such discrimination to be within the scope of prison discipline.

${ }^{217}$ Since their decisions are generally restricted to the particular hospital or prison for which they have charge, state institution administrators do not affect a broad scgment of society. Therefore, a violation of rights resulting from their decisions would not generally come to the attention of the polity. Thus, since a political resolution would be unlikely, a judicial remedy is needed. Furthermore, decisions regarding the treatment of patients and prisoners would not seem to be such important incidents of state sovereignty as would produce serious federal-state conflict if a degree of federal review were permitted.
} 
federal rights will occur frequently in prisons and mental hospitals, ${ }^{248}$ justify the current application of the more flexible test of reasonable discretion.

\section{Law Enforcement Officers}

As the class of state officials most immediately responsible for enforcing state laws, state and local law enforcement officers must exercise their authority in a way which frequently results in violations of federal rights. ${ }^{249}$ It is not surprising, therefore, that the greatest number of section 1983 actions have been brought against state law enforcement officers. ${ }^{250}$ From the first time the phrase "under color of" was defined with specific reference to police officers, ${ }^{251}$ they have been considered within the outer circle of potential defendants to section 1983 claims. Therefore, prior to the Monroe decision, a key issue in determining police liability was whether law enforcement officers were included within the inner circle of the immunity doctrine. ${ }^{252}$ After Monroe implicitly denied immunity to policemen, the

\footnotetext{
${ }^{248}$ See note 222 supra and accompanying text. Evidence of the extent of the violation of the federal rights of prisoners is scant. However, some notion may be derived by comparing the number of prisoner petitions to federal district courts with the total number of suits brought in the district courts. Thus in 1965, there were 7,096 prisoner petitions, fully one-ninth of the total petitions to district courts $(63,137$ total). U.S. Bureau OF Statistics, Stattstical ABstract of The United States 156 (87th ed. 1966).

20 The President's Commission on Law Enforcement and Administration of Justice has noted that "there is no profession whose members are more frequently tempted to misbehave . . . than law enforcement." THE President's CoMm'N ON Law Enforgenient and Administration of Justice, The Ghallenge of Crime in a FREE SocIETY 115 (1967). While recognizing that there was no way of estimating the amount of police misconduct, and therefore potential violations of federal rights, the Commission reported that it "does have evidence from its own studies and from police officials themselves, that in some cities a significant percentage of pohicemen assigned to high-crime areas do treat citizens with disrespect and, sometimes, abuse them physically." Ibid. Physical abuse would generally be considered violation of federal rights protected under $\$ 1983$. See Hardwick v. Hurley, 289 F.2d 529 (7th Cir. 1961). For statistics which might indicate the number of potential violations of federal rights by law enforcement officials, see note 97 supra. See generally Hall, Police and Law in a Democratic Society, 28 InD. L.J. 133 (1953); Note, Civil Rights Act Section 1983: Abuses by Law Enforcement Officers, 36 IND. L.J. 317 (1961).

${ }_{200}$ A recent count shows that approximately fifty-five cases based on $\$ 1983$ have reached the federal appellate level since the Monroe decision. After excluding reapportionment cases from the total number of $\$ 1983$ suits filed, claims against the police and law enforcement officers accounted for approximately one-fourth of all the cases. See note 274 infra.

${ }^{251}$ See Screws v. United States, 325 U.S. 91 (1945); note 45 supra and accompanying text.

252 Both before and after the Monroe decision, the doctrine of federal comity has applied to police officers. See Stefanelli v. Minard, 342 U.S. 117 (1951), notes 83-86
} 
chief question became whether proof of the two requisites of section 1983 would alone be sufficient to recover against police officers, or whether, in addition, some degree of personal fault on the part of the officer would have to be shown. ${ }^{253}$

Although no proponent addressed himself to the issue, an inductive evaluation of Republican statements regarding the Third Enforcement Act points to the conclusion that those enacting legislators did not envision that plaintiffs would have to overcome the defense of official immunity before obtaining redress against law enforcement officers. In the first instance, it can be inferred from Republican statements that the predecessor of section 1983 was not designed to abolish official immunity for judges and court officials. ${ }^{254}$ Therefore, if such state officials were not subject to section 1983 liability, the remedy would operate against only a few state officers, unless it did, in fact, apply to law enforcement officers. This observation gains added significance when viewed against the fact that the Republicans, attempting to justify the federal remedies of the precursor of section 1983, cited numerous examples of southern sheriffs failing to enforce the law equally. ${ }^{255}$ To the Democratic opponents of the 1871 Act,

supra and accompanying text. However, the strength of the doctrine as a protection for police officers against injunctions has varied depending on the nature of the factual situation. Thus, as in Stefanelli, when a police officer is to appear at a state trial, federal comity will prohibit a federal injunction against his testifying. On the other hand, it seems unlikely that federal courts would reach the same result if the plaintiff sought to enjoin law enforcement officials whose actions violate federal rights. See Dombrowski v. Pfister, 380 U.S. 479 (1965). The distinction seems to be that the function sought to be prohibited in the former case is typically considered an incident of state sovereignty; in the latter, the police's action is not so viewed.

Rarely does the question of an injunction against police officers arise, however, since in most cases, the violation of federal rights has actually occurred before the $\S 1983$ complaint is filed. Cases in which $\$ 1983$ injunctive relief has been sought against law enforcement officials include Rigney v. Hendrick, 355 F.2d 710 (3d Cir. 1965); Lance v. Plummer, 353 F.2d 585 (5th Cir. 1965), cert. denied, 384 U.S. 929 (1966); Due v. Tallahassee Theatres, Inc., 333 F.2d 630 (5th Cir. 1964); Wooten v. Ohler, 303 F.2d 759 (5th Cir. 1962).

${ }^{253}$ After the two requisites of $\$ 1983$ were proved, lower federal courts before Monroe frequently required plaintiffs to show in addition that the defendant policeman had had an intent to deprive the plaintiff of his federal rights before he could recover from the defendant. See, e.g., Hoftman v. Halden, 268 F.2d 280, 291 (9th Cir. 1959), overruled, Cohen v. Norris, 300 F.2d 24 (9th Cir. 1962). Intention to deprive, however, is not the sole kind of personal fault on the part of police officers which could have been required before liability would be imposed. For example, the standard of personal fault to be shown might have been negligence or recklessness. Therefore, the question dealt with in the second half of this section is whether some degree of personal fault must be demonstrated before plaintiffs can recover.

254 See notes 161-64 supra and accompanying text.

${ }^{255}$ Representative Hoar, speaking in support of the Third Enforcement Act, urged: 
there was no doubt that law enforcement officers could be held liable under section 1983. ${ }^{256}$ Nevertheless, they urged the defeat of the statute because liability would be imposed unjustly in two situations: where the policeman violates a federal right while properly executing a judicial order; ${ }^{257}$ and where he infringes a right as a result of "a mere error of judgment."258

After the Tenney decision recognized an inner circle of official immunity from section 1983 claims, ${ }^{259}$ the doctrine was extended to law enforcement officers by a few federal courts, ${ }^{260}$ but not by others. ${ }^{261}$ In any event, the resulting confusion was clearly rectified by the Supreme Court in Monroe v. Pape. ${ }^{262}$ Specifically, although Monroe did not speak in terms of immunity, by finding liability against the defendant police officers the Court sub silentio held that immunity was not available as a defense for law enforcement officers. ${ }^{263}$ Thus, in Cohen $v$. Norris, ${ }^{264}$ the Court of Appeals for the Ninth Circuit stated: "Monroe v. Pape involved police officers and, while the opinion of the court does not specifically discuss immunity, the result reached necessarily implies the rejection of such defenses

"[I]t is an effectual denial by a State of the equal protection of the laws when any class of officers ... . refuse to extend that protection. If every sheriff in South Carohina refuses to serve a writ for a colored man and those sheriffs are kept in office year after year by the people of South Carolina, and no verdict against them for their failure of duty can be obtained before a South Carolina jury, the State of South Carolina, through a class of officers who are its representatives to afford the equal protection of the laws to that class of citizens, has denied that protection." ConG. GLOBE, 42d Cong., Ist Sess. 334 (1871) [covering 1833-1873]. See, in addition, e.g., id. at 460 (remarks of Representative Coburn); $i d$. at app. 78 (remarks of Representative Perry).

${ }_{200}$ Democratic Representative Whitthorne pointed out early in the debate that under the predecessor of $\S 1983$, "suits may be instituted without regard to amount or character of claim by any person within the limits of the United States, who conceives that he has been deprived of any right ... under color of law ... of any State. That is to say, that if a police officer in the city of Richmond or New York should find a drnnken negro or white man upon the streets with loaded pistol flourishing it, etc., and by virtue of any ordinance, law, or usage, either of city or State, he takes it away, the officer may be sued, because the right to bear arms is secured by the Constitution, and such suit brought in distant and expensive tribunals." $I d$. at 337 . ${ }_{207} I d$. at 385 (remarks of Representative Lewis).

${ }^{268}$ Id. at 365 (remarks of Representative Arthur).

${ }^{250}$ See notes 59-66 supra and accompanying text.

${ }^{200}$ See Stift v. Lynch, 267 F.2d 237 (7th Gir. 1959); United States ex rel. Atterbury

v. Ragen, 237 F.2d 953 (7th Cir. 1956); Eaton v. Bibb, 217 F.2d 446 (7th Cir. 1954).

201 E.g., Lewis v. Brautigam, 227 F.2d 124 (5th Cir. 1955).

262365 U.S. I67 (1961); see note 88 supra.

${ }^{208}$ See note 96 supra and accompanying text.

20ะ300 F.2d 24 (9th Cir. 1962). 
as a general proposition."265 Lower federal courts quickly conformed to such an interpretation of the Monroe result. ${ }^{268}$

Several persuasive reasons justify the denial of official immunity for police officers. First, the traditional reason for granting immunity-to protect the independent judgment of "discretionary" officials-does not apply because policemen are merely "ministerial" officers, ${ }^{267}$ charged with implementing previously-made policy decisions and enforcing the law. Furthermore, the public interest in shielding the police officer from liability is slight, ${ }^{268}$ compared to the need for a civil remedy against potentially numerous police violations of federal rights. ${ }^{269}$ Additionally, denial of immunity to policemen helps to promote the strong public interest of ensuring respect by the police for the constitutional rights of the accused.270 Clearly,

${ }^{205}$ Id. at 33. (Emphasis added.)

${ }^{266}$ See, e.g., Lankford v. Gelston, 364 F.2d 197 (4th Cir. 1966); Basista v. Weir, 340 F.2d 74, 80 (3d Cir. 1965) (dictum); Due v. Tallahassee Theatres, Inc., 333 F.2d 630 (5th Cir. 1964); Sheridan v. Williams, 333 F.2d 581 (5th Cir. 1964); Stringer v. Dilger, 313 F.2d 536 (10th Cir. 1963); Smith v. Cremins, 308 F.2d 187 (9th Cir. 1962); Hardwick v. Hurley, 289 F.2d 529 (7th Cir. 1961).

267 See notes 51-52 supra and accompanying text. At first blush, it would seem that pohice and other "ministerial" officers ought not to be held liable, since either they have no discretion-as when acting under judicial order-and therefore should not be held responsible; or they do have discretionary duties-even in walking a "beat"-and therefore are "discretionary" officials. However, the underlying factors which determine "discretion" are not present when the office of policeman is considered. See Note, 66 HARv. L. REv. 488, $491-98$ (1953); note 52 supra. See generally Davis, Administrative Officers' Tort Liability, 55 MICH. L. REv. 201 (1956); Gray, Private Wrongs of Public Servants, 47 CALIF. L. REv. 303 (1959).

208 In fact, it has recently been emphasized that "from the point of view of policecommunity relations, it is extremely important that policemen be held to account for rudeness and disrespect" toward members of the public. THE PREsident's CoMm'N ON Law Enforgement and Administration of Justice, The Challenge of Crume in a free SOCIETY 116 (1967).

${ }^{200}$ See Prosser, TorTs $\$ 126$ (3d ed. 1964). The need for a federal civil remedy is demonstrated first by the fact that police violations of federal rights greatly outnumber the actual infringements of such rights by any other state official. See notes 97, 249-50 supra for statistics on police violations. Secondly, plaintiffs suing state officers for infringement of federal rights are usually more likely to get a fair hearing in federal court because of the reluctance of state courts to entertain cases against state police officers. See Note, 36 InD. L.J. 317, 321 (1961). See generally Hall, Police and Law in a Democratic Society, 28 IND. L.J. 133 (1953); Note, 46 Colum. L. REv. 614 (1946).

${ }^{270}$ Recent decisions by the Supreme Court emphasize the current judicial concern that the rights of the accused be respected by police officers. See, e.g., Miranda v. Arizona, 384 U.S. 436 (1966) and Escobedo v. Illinois, 378 U.S. 478 (1964) (rights of the accused during police questioning); Gideon v. Wainwright, 372 U.S. 335 (1963) (right to counsel when tried for serious crimes); Mapp v. Ohio, 367 U.S. 643 (1961) (freedom from illegal search and seizure). Lower federal courts have implemented this concern by finding liability against police officers when sued under $\S 1983$. For example, in Lankford v. Gelston, 364 F.2d 197 (4th Cir. 1966), the Court of Appeals for the 
police officers will be more likely to observe those rights if they know that immunity will not protect them from liability under section $1983 .{ }^{271}$

Besides its implicit rejection of immunity as a defense for policemen sued under section 1983, the Monroe decision also held that police liability did not depend on proof of a specific intent to deprive a person of the federal right to due process. ${ }^{272}$ The Monroe Court stated that section 1983 "should be read against the background of tort liability that makes a man responsible for the natural consequences of his actions."273 Consequently, a plaintiff suing under section 1983 need only prove the two requisites-deprivation of federal rights "under color of" state law-to state a cause of action against a policeman. ${ }^{274}$

Fourth Gircuit, in holding an officer liable, stated: "[T] he police department is society's instrumentality to maintain law and order, and to be fully effective it must have public confidence and cooperation." Id. at 204. This can be accomplished only if police employ their enforcement measures according to law. Therefore, "law observance by the police cannot be divorced from law enforcement." Ibid.

${ }^{271}$ Lower federal courts have offered further justifications based on public policy for denying police officers the defense of immunity in $\$ 1983$ suits. Thus, in York v. Story, 324 F.2d 450 (9th Cir. 1963), cert. denied, 376 U.S. 939 (1964), the Court of Appeals for the Ninth Circuit said that security of federal rights from police violations is "implicit in the concept of ordered liberty." $I d$. at 455 . In addition to the desire to maintain "ordered liberty" in our society, it seems important to allow persons whose rights have been deprived to recover compensatory (and in cases of intentional deprivation of rights, punitive) damages against the officer who caused the infringement. See Stringer v. Dilger, 313 F.2d 536 (10th Cir. 1963); Hardy v. Kirchner, 232 F. Supp. 751 (E.D. Pa. 1964).

${ }_{272}$ See note 100 supra and accompanying text. As the Court of Appeals for the Ninth Gircuit pointed out in Cohen v. Norris, 300 F.2d 24 (9th Cir. 1962), the requirement of intent to deprive a person of rights as a necessary element of a due process claim under $\$ 1983$ probably arose by mistake. Snowden v. Hughes, 321 U.S. 1, 8 (1944), established the requirement of intent to discriminate in order to state an equal protection claim, and that remains the law today. However, cases like Hoffman v. Halden, 268 F.2d 280 (9th Cir. 1959), overruled, Cohen v. Norris, supra and Agnew v. City of Compton, 239 F.2d 226 (9th Cir. 1956), cert. denied, 353 U.S. 957 (1957), overruled, Cohen v. Norris, supra, read the decision in Snowden as requiring intent to deprive of rights as an element of a due process claim. In removing this requirement, Monroe merely rectified an interpretive error.

27365 U.S. at 187.

274 See, e.g., Herschel v. Dyra, 365 F.2d 17 (7th Cir.), cert. denied, 385 U.S. 973 (1966); Basista v. Weir, 340 F.2d 74 (3d Cir. 1965); Stringer v. Dilger, 313 F.2d 536 (10th Cir. 1963); Smith v. Cremins, 308 F.2d 187 (9th Cir. 1962); Colien v. Norris, 300 F.2d 24 (9th Cir. 1962).

Since the Monroe decision in 1961, cases based on $\S 1983$ have been brouglit against various law enforcement officers alleging a deprivation of the following federal rights: Freedom of Expression: e.g., Herschel v. Dyra, supra; Corsican Prods. v. Pitchess, 338 F.2d 441 (9th Cir. 1964); Smith v. Cremins, supra; Wooten v. Ohler, 303 F.2d 759 (5th Cir. 1962); Freedom from Illegal Search and Seizure: e.g., Lankford v. Gelston, 364 
However, the federal courts have not interpreted Monroe as requiring the imposition of immediate liability in all cases in which the two requisites are proved.275 Instead they have allowed police officers to avoid liability under section 1983 in two distinct situations. First, if a law enforcement official violates a federal right while propexly executing a judicial order, he will be completely insulated from

F.2d 197 (4th Cir. 1966); Armstrong v. Rushing, 352 F.2d 836 (9th Cir. 1965); Sheridan v. Williams, 333 F.2d 581 (9th Cir. 1964); York v. Story, 324 F.2d 450 (9th Cir. 1963), cert. denied, 376 U.S. 939 (1964); Cohen v. Norris, supra; Freedom from Arbitrary Discrimination: e.g., Due v. Tallahassee Theatres, Inc., 333 F.2d 630 (5th Cir. 1964); Nesmith v. Alford, 318 F.2d 110 (5th Gir. 1963), cert. denied, 375 U.S. 975 (1964); Marshall v. Sawyer, 301 F.2d 639 (9th Cir. 1962); Freedom from Coerced Confessions: e.g., Stringer v. Dilger, supra; Hardwick v. Hurley, 289 F.2d 529 (7th Cir. 1961); Right to Due Process: e.g., Nelson v. Hall, 368 F.2d 103 (9th Cir. 1966); Basista v. Weir, supra; Due v. Tallahassee Theatres, Inc., supra; Wooten v. Ohler, supra; Hughes v. Noble, 295 F.2d 495 (5th Cir. 1961), cert. denied, 371 U.S. 828 (1962); Hardwick v. Hurley, supra. Stringer v. Dilger, supra, and Cohen v. Norris, supra, recite lists of federal rights which, if violated, can become the basis of a $\$ 1983$ complaint.

Plaintiffs who establish $\$ 1983$ damage claims against nonimmune state officials may find such defendants judgment-proof. After Monroe, it has been clear that $\$ 1983$ cannot provide a basis for recovery against his employer, the state or municipality. Monroe v. Pape, 365 U.S. 167, $191-92$ (1961); note 94 supra. However, it seems that society should bear the cost of the mistakes of its agents, just as business enterprises must pay damages for the torts of their servants. It appears that such governmental liability could only be imposed by Congress-and not by the courts-if the states or municipalities are not willing to take the initiative. This suggestion has been recommended in U.S. Civil Rights Comm'N, LAw Enforcenent: A Report on Equal ProTECTION IN THE SOUTH 179 (1965).

${ }^{275}$ Obviously, Iaw enforcement officers are entitled to deny the allegations of the complaint and then prove to the satisfaction of the court either that they were not acting "under color of" state law, or that the plaintiff had been deprived of no federal rights. A defense based on the theory that the officer violated no federal right is frequently employed. See, e.g., Kamsler v. M.F.I. Corp., 359 F.2d 752 (7th Cir. 1966); Rigney v. Hendrick, 355 F.2d 710 (3d Cir. 1965), cert. denied, 384 U.S. 975 (1966); Harris v. Turner, 329 F.2d 918 (6th Cir. 1962), cert. denied, 379 U.S. 907 (1964); Magee v. Williams, 329 F.2d 470 (7th Cir. 1964); Kinney v. Johnson, 319 F.2d 123 (5th Cir. 1963); Gager v. "Bob Seidel," 300 F.2d 727 (D.C. Cir.), cert. denied, 370 U.S. 959 (1962).

Furthermore, the law enforcement officer may be able to escape liability under $\$ 1983$ by proving that the applicable statute of limitations had run in relation to the plaintiff's claim. See, e.g., Minchella v. Estate of Skillman, 356 F.2d 52 (6th Cir.), cert. denied, 385 U.S. 861 (1966); Crawford v. Zeitler, 326 F.2d 119 (6th Cir. 1962). See also Wojtas v. Village of Niles, 334 F.2d 797 (7th Cir. 1964), cert. denied, 379 U.S. 64 (1965). In some cases, courts have dismissed claims against police officers because they deemed the complaints "frivolous" or "spurious." However, dismissal on this basis is improper until after the court has taken jurisdiction of the case. See, e.g., Armstrong v. Rushing, supra note 274; Harmon v. Superior Court of Calif., 307 F.2d 796 (9th Cir. 1962). The doctrine of abstention has also been used by some federal courts to avoid finding liabihty against police officers. However, the availability of this doctrine in civil rights cases has recently been restricted. See, e.g., Dombrowski v. Pfister, 380 U.S. 479 (1965); McNeece v. Board of Educ., 373 U.S. 668 (1963); Marshall v. Sawyer, supra note 274. 
liability, ${ }^{276}$ in the same manner that clerks of court and state prison or hospital administrators are protected. ${ }^{277}$ The judge's cloak of official immunity shields the officer because he has no reasonable choice but to comply with the order, even though his actions violate federal rights. The justification appears to be that obedience and respect for judicial orders is deemed more important than vindication of federal rights by means of a civil suit. ${ }^{278}$

A second defense which law enforcement officials may assert against section 1983 damages claims is that they acted with good faith and probable cause. Although a number of lower federal courts had considered this defense, ${ }^{270}$ a question still remained as to whether it had been abrogated by Monroe. ${ }^{280}$ However, in Pierson v. Ray, ${ }^{281}$ the Supreme Court forthrightly approved the defense of good faith and probable cause. ${ }^{282}$ In Pierson, defendant police officers arrested plaintiffs, Negro and white clergymen, for breaching the peace by participating in a civil rights demonstration. When similar arrests

${ }^{278}$ Thus, in Rhodes v. Houston, 202 F. Supp. 624 (D. Neb. 1962), aff'd, 309 F.2d 959 (8th Cir.), cert. denied, 372 U.S. 909 (1963), the court stated: "Authorities performing orders issuing from a court are provided immunity when they do nothing other than perform such orders." Id. at 636. See, in addition, Furlburt v. Graham, 323 F.2d 723 (6th Cir. 1963); Puett v. City of Detroit, Department of Police, 323 F.2d 591 (6th Cir. 1963), cert. denied, 376 U.S. 957 (1964); Hoffman v. Halden, 268 F.2d 280 (9th Cir. 1959), overruled on other grounds, Cohen v. Norris, 300 F.2d 24 (9th Cir. 1962).

${ }^{277}$ See notes 205-07, 226-32 supra and accompanying text.

${ }^{278}$ See cases cited note 276 supra.

${ }^{270}$ See, e.g., Carmack v. Gibson, 363 F.2d 862 (5th Cir. 1966); Beauregard v. Wingard, 362 F.2d 901 (9th Cir. 1966); Attreau v. Morris, 357 F.2d 871 (7th Gir.), cert. denied, 385 U.S. 832 (1966); Lucero v. Donovan, 354 F.2d 16 (9th Cir. 1965); Anderson v. Haas, 341 F.2d 497 (3d Cir. 1965); Basista v. Weir, 340 F.2d 74 (3d Cir. 1965); Marland v. Heyse, 315 F.2d 312 (10th Cir. 1963); Hughes v. Noble, 295 F.2d 495 (5th Cir. 1961) (per curiam). The probable cause defense was indirectly affirmed in Kinney v. Johnson, 319 F.2d 123 (5th Cir. 1963), which held there was no denial of federal rights when arrest was made pursuant to legal warrant. On the other hand, in Nesmith v. Alford, 318 F.2d 110 (5th Gir. 1963), cert. denied, 375 U.S. 975 (1964), the court held police defendants hable under $\S 1983$ for arresting without a warrant.

Related to the probable cause defense is the rule that policemen sued under $\S 1983$ for depriving others of freedom from unreasonable search and seizure are liable only if the police action is deemed "unreasonable" by the jury. See Morgan v. Labiak, 368 F.2d 338 (10th Cir. 1966).

${ }^{280}$ In Pierson v. Ray, 352 F.2d 213 (5th Cir. 1965), rev'd in part, 386 U.S. 547 (1967), the Court of Appeals for the Fifth Circuit held police officers hable even if they had acted with probable cause in making the arrest. The court seemed to believe that this result was dictated by Monroe.

282386 U.S. 547 (1967).

${ }^{283} I d$. at 557. The Court announced its decision in these words: "We hold that the defense of good faith and probable cause, which the Court of Appeals found available to the officers in the common-law action for false arrest and imprisonment, is also available to them in the action under $\$ 1983 . "$ Ibid. 
were later declared unconstitutional, ${ }^{283}$ plaintiffs sued the police for damages under section 1983. The officers defended on the theory that "they should not be liable if they acted in good faith and with probable cause in making an arrest under a statute that they believed to be valid."284 After finding that the Mississippi common law accorded the police protection from tort liability when acting with probable cause, ${ }^{285}$ the Supreme Court ruled that the same defense was available to them under section $1983 .{ }^{286} \mathrm{Mr}$. Chief Justice Warren specifically stated that the Monroe decision did not abolish this "limited privilege."287 If it had, the law enforcement officer would be forced "to choose between being charged with dereliction of duty if he does not arrest when he has probable cause, and being mulcted in damages if he does." 288 Indeed, Monroe actually dictated the recognition of the defense by requiring that section 1983 "be read against the background of tort liability." ${ }^{280}$ As the Pierson majority pointed out, "part of the background of tort liability, in the case of police officers making an arrest, is the defense of good faith and probable cause."200

${ }^{283}$ See Thomas v. Mississippi, 380 U.S. 524 (1965) (per curiam); note 172 supra.

284386 U.S. at 555.

${ }^{285} \mathrm{Ibid}$. The Mississippi rule is the prevailing view among American jurisdictions. See Restatement, Torts $\$ 121$ (2d ed. 1965).

${ }^{280} \mathrm{Id}$. at 557. The Court's actual disposition of the case was to remand for a jury determination as to whether the defendant officers actually had probable cause to arrest the plaintiffs. At the initial trial of the case, the jury had decided in favor of the defendant policemen, but the Court found that "its verdict was influenced by irrelevant and prejudicial evidence." Id. at 558.

237 Id. at 555 .

288 Ibid.

${ }^{288}$ Monroe v. Pape, 365 U.S. 167, 187 (1961), quoted in 386 U.S. at 556.

${ }^{200} \mathrm{Ibid}$. The Pierson decision is not free of problems, one of its major ambiguities being the meaning of the phrase "good faith and probable cause." The test of good faith is generally considered subjective in nature: that is, the question is whether the officer performed his duty of arrest with a bona fide, honest belief that the arrest was justified. By contrast, the prohable cause standard generally implies an objective evaluation of the circumstances by the court or jury to determine whether the factual situation would cause a reasonable man to believe that an arrest was warranted. See Beck v. Ohio, 379 U.S. 89, 9I (1964); Prosser, TorTs § 113, at 859-6I (3d ed. 1964). Thus, in ordinary tort law probable cause sets a higher standard than good faith, and is inclusive of good faith. However, Pierson makes no explicit distinction between the two.

The resolution of this difficulty secms to lie in reading the terms "good faith" and "probable cause" conjunctively: both must be present before the Piersonapproved defense can be asserted hy policemen. The language of the Pierson decision supports this interpretation, for the Chief Justice never mentioned the defense except by the language of "good faith and probable cause." 386 U.S. at 557. (Emphasis added.) Furthermore, in discussing the prevailing vicw concerning the law of arrest, 
Several public policies appear to be promoted by allowing a law enforcement officer to avoid liability under section 1983 while acting either according to judicial order or with probable cause. In the first place, the courts' refusal to hold policemen liable when properly enforcing a judicial order avoids the incongruity of imposing liability for exercising a mandatory duty commanded by the court. In addition, by finding liability for deviation from a judicial order in a manner which would violate federal rights, the courts encourage loyalty and obedience to superiors. Secondly a good faith and probable cause defense conforms to the general standard for determining the validity of an arrest without a warrant. ${ }^{291}$ Thus, no new complications are added to the law. In short, by making the determinative factor of police liability either loyalty to a responsible superior authority or the rational exercise of the officer's own sound judgment, the two exceptions to police liability under section 1983 place emphasis on the necessity for careful and responsible enforcement of the law.

\section{CONCLUSION}

Section 1983 is not the sole federal remedy available to redress violations of federal rights by persons acting "under color of" state law.292 Indeed, injunctions or damages may be obtained under other

the Court emphasized the requirement of probable cause over that of good faith. Ibid. Since it is the generally prevailing state common law defense which the Court incorporated into the law governing $\$ 1983$, it seems that the standard must be at least good faith and probable cause. If "good faith" alone were required to avoid $\S 1983$ liability, the standard of evidence required for federal civil liability would be lower than that for state liability. Clearly, this was not the intended result.

A second problem is that Pierson seemingly conflicts with the three earliest Supreme Court decisions under § 1983: Lane v. Wilson, 307 U.S. 268 (1939); Nixon v. Ferndon, 273 U.S. 536 (1927); and Myers v. Anderson, 238 U.S. 368 (1915). See notes 33-34 supra and accompanying text. In those cases, defendant election officials were held liable under $\S 1983$ for violating plaintiffs' voting rights while acting pursuant to a state law which had not yet been declared unconstitutional. Their good faith execution of the law was no defense to their liability. Nevertheless, the Pierson result seems more reasonable, for as Mr. Chief Justice Warren pointed out, the "policeman's lot is not so unhappy" that he is placed in the dilemma of having to choose between violating his duty by not arresting when he has probable cause and being liable in damages if he does make the arrest under a law subsequently declared unconstitutional. 386 U.S. at 555 .

${ }^{201}$ See, e.g., Beck v. Ohio, 379 U.S. 89, 91 (1964) (as applied in search and seizure); Wong Sun v. United States, 371 U.S. 471, 479 (1963) (as applied to arrests without a warrant).

${ }^{202}$ Section 1983 may be contrasted to many other federal civil rights laws which have different purposes, but which are supplements to $\S 1983$ as part of the overall federal plan to protect federal rights. Thus, $\$ 1983$ does not authorize the removal 
laws, such as the federal conspiracy statute, section 1985 (3) of title 42 of the United States Code; ${ }^{293}$ the Civil Rights Act of 1964;204 and the Voting Rights Act of 1965. ${ }^{295}$ However, section 1983 requires no showing of a purpose to violate federal rights, as seems to be required under section 1985 (3)..$^{296}$ Moreover, relief is available for any denials of federal rights under section 1983, whereas the violation must fit the narrow categories of infringements specified by the Civil Rights Act of 1964 and the Voting Rights Act of 1965 before federal redress is available under those enactments. ${ }^{207}$ In short, as

of cases from state to federal courts when a civil rights issue is involved. That mode of federal relief is available under 28 U.S.C. $\$ 1443$ (1964). Neither does $\S 1983$ enable one who has been convicted in violation of his federal rights to be released or retried, that function being served by the federal habeas corpus provision, 28 U.S.C. $\$ \S 2241.55$ (1964). Furthermore, $\$ 1983$ does not provide protection for society against those violating federal rights "under color of" authority, as does 18 U.S.C. $\$ 242$ (1964), §1983's criminal counterpart. Finally, § 1983 does not empower the President to employ federal troops, militia, or marshals to suppress domestic civil rights violence, as do 10 U.S.C. $\S \S 332-33$ (1964).

${ }^{208} 42$ U.S.C. $\$ 1985$ (3) (1964). The usefulness of this statute was severely limited by the Supreme Court in Collins v. Hardyman, 341 U.S. 651 (1951), where the Court stated that the statute would be effective against private citizens only if the conspiracy was of the proportions of the Klan of 1871. While the Collins standard need not be met where state officers are part of the conspiracy, many claims based on the equal protection clause require proof of a purpose to discriminate. Sec Snowden v. Hughes, 321 U.S. 1, 8 (1944). Thus, it would seem easier to establish a $\$ 1983$ due process claim for damages against the officer and avoid the necesssity to prove the existence of a conspiracy as required by $\S 1985$ (3).

20442 U.S.C. $\$ \$ 2000 \mathrm{a}-\mathrm{h}$ (1964). The Civil Rights Act of 1964 empowers the Attorney General of the United States to initiate actions for injunctive relief upon receiving complaints of state violations of the equal protection of the laws. It does not permit him to intervene where the claim against the state rests on due process of law. See U.S. Civil Rights Comm'n, LAw Enforcement: A Study of Equal Protection IN THE South 123-24 (1965). However, the 1964 Act takes into consideration the importance of maintaining the federal-state balance, as explained in Stefanelli v. Minard, 342 U.S. 117 (1951), notes 81-86 supra, by providing statutory delays before the federal agencies may act, in order to give the States the first opportunity to correct the problem. See, e.g., 42 U.S.C. $2000 \mathrm{a}-3$ (c), 42 U.S.C. $2000 \mathrm{e}-5$ (b) (1964).

205 The Voting Rights Act of 1965, 42 U.S.C. $\$ \S 1973-1973 p$ (Supp. I 1965), authorized federal civil relief and criminal penalties for state-caused denials of the right to vote. Thus, the Attorney General of the United States may seek injunctive relief against the state, its agents, or persons acting "under color of" state law who deprive anyone of his right to vote, as protected by the equal protection clause of the fourteenth amendment. 42 U.S.C. 1973 (c) (Supp. I 1965). 42 U.S.C. 1973j (a), (b), and (c) (Supp. I 1965) provide criminal penalties for those who violate the rights protected by the 1965 Act. 42 U.S.C. $\$ \S 1973$ j (d) and (e) (Supp. I 1965) empower the Âttorney General to seek federal preventive relief and court orders to require state officials to permit all qualified persons to vote.

${ }^{206}$ See Collins v. Hardyman, 341 U.S. 651 (1951); note 293 supra. Another major difference between $\S 1983$ and $\S 1985(3)$ is that damages is the only remedy available under $\S 1985(3)$.

${ }^{207}$ Along with $\S 1985$ (3), the Civil Rights Act of 1964 and the Voting Rights Act of 
the broadest and most general of federal civil remedies for civil rights violations, section 1983 is available to fill the gaps left by the more narrowly drawn statutes.

As a general civil remedy, section 1983 has been increasingly utilized during the last two decades to compensate persons whose federal rights have been infringed. 298 The statute seems to have been reasonably effective in providing redress against law enforcement officials, prison and hospital administrators, and local boards and councils. However, even against these officials, section 1983 is not free of such difficulties as the unpredictability of jury verdicts; the fact that the individual plaintiff must take the initiative to institute the suit; and the fear that the grievance complained of will be considered a valid restriction of liberty or property imposed with "reasonable discretion." Furthermore, when the remedies of section 1983 are sought against judges, prosecutors, legislators, or high executive officials, the doctrines of official immunity and federal comity operate as substantial obstructions to recovery. On the other hand, even though these doctrines may restrict the aim of section 1983 to provide a federal means of civil redress for infringements of federal rights, they seem required by the necessity of resolving the conflict between the purpose of section 1983 and the continued efficacy of state government in our federal structure. ${ }^{299}$ In sum, it is because the federal courts have been able to utilize the doctrines of comity and immunity in section 1983 suits that a reasonable compromise of the conflict and a workable balance between state and federal governments has been attained, while at the same time section 1983 has continued to

1965 are designed to enforce only the equal protection clause of the fourteenth amendment. By contrast, $\S 1983$ is available as a federal remedy to persons who are deprived of procedural and substantive due process of law, as well as equal protection of the laws. Since the due process clause applies many of the rights protected in the first eight amendments against the states, $\$ 1983$ seems immensely more useful than any federal remedy based solely on equal protection.

${ }^{208}$ Indeed, virtually the enitre judicial evolution of $\S 1983$ has taken place over a period starting in 1945 with Picking v. Pennsylvania R.R., 151 F.2d 240 (3d Cir. 1945), cert. denied, 332 U.S. 776 (1947).

${ }^{280}$ Official immunity promotes the efficacy of state government by insuring the independence of decision-making by "discretionary" officers. Federal comity seeks to prevent federal intervention into state functions which are typically considered incidents of state autonomy. Federal respect for state autonomy rests on the premise that, in our federal system, the states ought to be allowed to carry out many activities without federal interference. See note 71 supra. 
provide civil relief in the majority of cases where federal rights are violated by state officials..$^{300}$

${ }^{300}$ There is a growing body of evidence that gross inequities exist in the administra. tion of government at the state and local level, especially in the courts. See James, The Crisis in the Courts, Christian Science Monitor, Apr. 12, 1967, p. 13; Apr. 19, 1967, p. 11; Apr. 26, 1967, p. 9; May 3, 1967, p. 9; May 10, 1967, p. 9; May 17, 1967, p. 9; May 24, 1967, p. 9. See generally THE President's Comm'N ON LAw ENForcentent and Administration of Justice, The Challenge of Crime in a Free Society (1967). Therefore, the argument has been advanced that an expanded civil liability under $\S 1983$ could stimulate much-needed reforms in state governmental procedures. However, to accomplish this end through the means of $\$ 1983$, the abolition of the doctrines of comity and immunity would be required. Yet it seems that direct political and administrative revisions would be more desirable than the indirect approach of threatening state officials with personal liability in federal court. Furthermore, the abrogation of immunity and comity would give free rein to the consequences of which Judge Learned Hand expressed fear in Gregorie v. Biddle, 177 F.2d 579, 581 (2d Cir. 1949), cert. denied, 339 U.S. 949 (1950); note 212 supra. 